\title{
SO-CALLED PARTHENOGENESIS IN THE WHITE MOUSE.
}

\author{
H. M. KINGERY, \\ Department of Histology and Embryology, \\ Cornell University, Ithaca, New York.
}

In atretic follicles of ovaries in a number of different mammals the oöcytes go through a process which somewhat resembles maturation. Various stages of mitosis are seen and frequently a first polar body is present. In some cases the oöcyte is found divided up in a number of small parts some of which contain nuclei. This process has been described as a beginning of parthenogenetic cleavage and also as degenerative fragmentation. Bonnet ('oo) gives a review of the work done up to that time and after considering all the evidence decides that the mitotic figures seen in such egg-cells are not those of parthenogenetic cleavage but are rather those of more or less abnormal maturation stages. Newman ('I3) reviews briefly the work done since Bonnet's paper and presents the results of his studies on the armadillo in support of the view that "a limited amount of parthenogenetic cleavage occurs but that development proceeds no farther than two or three cell divisions." Van der Stricht ('or), who worked on the bat claims that in that form is found a beginning of true parthenogenesis. Rubaschkin ('o7), who studied the guinea-pig, and Athias ('o9), for the dormouse, state that the phenomena are to be interpreted as degenerative fragmentation which at the most merely resembles parthenogenesis.

In material which I have been preparing for a study of oögenesis in the white mouse I found that in the ovaries of young mice approaching sexual maturity there is a very extensive degeneration of follicles, most marked between the ages of twenty-five and forty days. As the work on this problem has all apparently been done on the ovaries of fully or young adult mammals, it was thought worth while to use the material in these immature ovaries $^{1}$ for a study of this so-called parthenogenesis.

${ }_{1}^{1}$ The material used for this work consists of ovaries of white mice varying in age from twenty to ninety days. These ovaries were fixed in Carnoy's fixer 
In the white mouse, it is certain that the changes taking place in the oöcytes are in some way correlated with the atresia of the follicles, for in follicles which have not begun to degenerate the egg-cells are normal in appearance and the nuclei are normal resting nuclei. But in follicles overtaken by atresia the cytoplasm of the oöcytes is found to stain more deeply with acid stains, fat granules are found in large numbers, and the nuclei are in various stages of mitosis. The degeneration of the follicle in some way stimulates the oöcyte so that it passes through more or less abnormal maturation stages.

The early prophase is probably passed through very rapidly as no stages were seen of nuclei between the resting stage and the equatorial plate stage. Lams and Doorme ('o8) did not observe the stages between the resting nucleus and the first polar spindle in the normal maturation of the egg of the white mouse. Kirk-

(“6:3:I”), Hermann's, and Flemming's fluids. Heidenhain's iron hematoxylin, Jenner's blood stain, and Flemming's triple stain were used. Sections were stained over night in Jenner's stain, diluted with three parts of water; this stain was used after fixation in Carnoy's fluid and gave excellent results for some purposes. The cytoplasm of degenerating egg-cells was stained a much deeper pink or red than that of normal egg-cells. The nuclei of follicle cells and phagocytic cells were stained a deep blue. The stain will fade after a time, however.

A modification of theshorter method of Flemming's triplestain was used. Sections of material fixed for two to four hours in Flemming's or Hermann's fluid were bleached in a dilute solution of hydrogen peroxid and after rinsing were placed in a four per cent. solution of ferric alum for four to twelve hours. The sections were then rinsed in distilled water, dipped in the safranin solution a second or two, rinsed again in distilled water, and placed in the gentian violet solution for two to ten or fifteen minutes. Then after rinsing in distilled water the sections were stained in the orange $\mathrm{G}$ for ten to sixty seconds. After dehydrating rapidly in absolute alcohol the sections were differentiated in clove oil under the control of the microscope. The clove oil was removed by toluene or xylene and the sections mounted in balsam. By this method the cytoplasm of the oöcytes was stained a yellow-brown, the chromosomes were stained a violet, and the spindle fibers a dark violet-almost purple. The method is rather capricious but when successful, the spindle fibers stand out very distinctly against the yellow-brown cytoplasm of the egg-cell. The method was used principally to bring out the spindle fibers, as the chromosomes are not stained so distinctly or sharply as by the iron hematoxylin method.

The solutions used are as follows:

I. $\left\{\begin{array}{l}\text { Safranin, saturated solution in absolute alcohol, I part. } \\ \text { Safranin, saturated solution in distilled water, I part. }\end{array}\right.$

2. Gentian violet, I per cent. solution in distilled water.

3. Orange G, 2 per cent. solution in distilled water. 
ham ('o8) describes very briefly a few stages of the prophase of the first maturation division in this same form.

Descriptions of the first and second polar spindles in normally maturing oöcytes do not agree. Sobotta ('o7) says: "Wenn auch namentlich die Breite individuell etwas wechselt, so beträgt Länge wie Breite des ersten Richtungsspindel der Maus doch stets das Doppelte der Masse des zweiten Richtungsspindel, die Breite ist in der Regel mehr als doppelt so gross." Lams and Doorme, on the other hand, find that the first and second polar spindles are of exactly the same length and diameter. They state: "D'une façon certaine, un ovule à second fuseau ne se distingue d'un ovule à premier fuseau que par la présence, dans le premier cas, du premier globule polaire." Kirkham agrees with Sobotta in saying that the first polar spindle is larger than the second and also in describing the chromosomes as differing in size and shape in the two spindles.

In regard to oöcytes in atretic follicles, Athias says of the spindle, first or second: "Sa forme et ses dimensions sont variables, mais il n'y a pas des caractères qui soient propre au premier ou au second fuseau; la présence concomitante d'un premier globule polaire est, d'après ce que j'ai pu constater dans mes préparations, le seul critérium pour affirmer si l'on est en présence d'un second fuseau de direction." In my own preparations the lengths and diameters of a number of first and second polar spindles in atretic oöcytes were measured. For the first polar spindles, the average length was found to be $24.7 \mu$, the diameter I $2.8 \mu$, while for the second, the average length was $25.9 \mu$ and the diameter $8.7 \mu$. Allowing for error in measuring, the spindles are seen to be of about the same length, while the second polar spindles are about two thirds the diameter of the first.

In degenerating oöcytes of the white mouse the first polar spindles are found to be of two general forms: slender, with the achromatic fibers meeting at a point at each end, and thick, "barrel-shaped," with broadly rounded ends. These two kinds are met with in about equal numbers. In both, the chromosomes are arranged with their long axes parallel to that of the spindle. The chromosomes are not arranged around the periphery of the 
spindle, but are scattered in the plane through the middle of the spindle, at right angles to its length. The chromosomes of the first polar spindle are larger than those of the second and are long with a marked thickening or swelling at the middle. This thickening is at one side of the chromosomes and it is at this point that division takes place. The division is apparently transverse. This account agrees with those of Sobotta and Kirkham for the normal first maturation spindle.

The chromsomes are grouped so closely together and overlap to such an extent that it is difficult to determine their number with accuracy. They apparently vary in number from twelve to twenty-four, the larger numbers being due to a precocious division of some, while others are still undivided.

Descriptions of the appearance of the spindle itself differ. Sobotta, Kirkham, and Lams and Doorme, state that polar radiations or asters are not present in first polar spindles of normally maturing oöcytes, and Athias agrees with them in the case of degenerating egg-cells. Rubaschkin, however, describes in atretic oöcytes of the guinea-pig polar radiations arising from a clear area or centrosphere. Kirkham describes centrosomes consisting of several minute granules at the poles of the spindles. Sobotta states that there are no centrosomes in the first polar spindles of normally maturing oöcytes, and Athias finds none in degenerating egg-cells. In my own preparations radiating fibers are to be seen at the poles of a few first polar spindles; these, however, are not to be considered true asters, but spindle fibers which have broken away from the spindle. This will be discussed more in detail further on. No centrosomes are found in any of these degenerating oöcytes. The spindle fibers are not divided into central spindle fibers and mantle fibers; the fibers with chromosomes attached are intermingled with those which are not connected with chromosomes. The two kinds do not differ in appearance or staining reaction. The spindle itself usually lies at right angles to the radius of the oöcyte, until it swings around to a radial position for the formation of the polar body. (See Figs. I, 2 and 5.)

The stages in the formation of the first polar body must follow one another rapidly for only a few of these stages were 
observed. Some of the chromosomes divide earlier than others and consequently the metaphase is not so distinctly marked as in some forms. A few instances of a telophase were seen, in some of which both groups of daughter-chromosomes are in the oöcyte, with no indication as yet of a division of the cytoplasm to form the polar body, while in the others the constricting off of the polar body may be plainly seen. After the first polar body is formed the chromosomes remaining in the oöcyte do not form a resting nucleus but at once enter the second polar spindle.

The second polar spindle, as stated above, is of about the same length as the first, while only two thirds or three fourths as much in diameter. The chromosomes as seen in the equatorial plate stage are short and rod-like and straight or slightly curved. They are not as long or as much curved as Kirkham describes in the second polar spindles of normally maturing oöcytes. The chromosomes are arranged with their long axes parallel to that of the spindle itself and as in the first polar spindle are scattered in a plane at right angles to the length of the spindle. This differs from Kirkham's account of the normal second polar spindle, in which he states that in general the chromosomes lie with their long axes across the spindle. In the spindles of these degenerating egg-cells some of the chromosomes are constricted across the middle in preparation for division, having the appearance of elongated dumb-bells; others have not started to divide and have the typical rod-like form. Others still have already divided and are short and thick, their length only slightly exceeding their diameter. (See Figs. 3 and 4.) This division as well as the first is apparently transverse in the mouse. The chromosomes are crowded together, as in the first polar spindle, making an accurate count difficult; there are from twelve to thirty, owing to the fact that some divide sooner than others.

Descriptions of the appearance of the second polar spindle are as conflicting as those of the first. Sobotta states that in normally maturing oöcytes there are neither centrosomes nor polar radiations. Lams and Doorme describe centrosomes but say that polar radiations are absent; Kirkham states that both centrosomes and polar radiations are present in some cases. In second polar spindles of degenerating oöcytes Athias states 
that neither centrosomes nor polar radiations are present. In my own preparations radiating fibers are to be seen at the poles of a number of second polar spindles. As in the case of the first polar spindles, however, these are not to be considered true asters, but spindle fibers which have broken away from the spindle, and have assumed a radial position at the ends of the spindles. This will be discussed more in detail later. In general, centrosomes are absent in second polar spindles of atretic oöcytes, but are present in some cases. When they are seen, they consist of a few minute granules which stain deeply and are either in a compact group at the poles of the spindle or are somewhat spread out forming a sort of cap for the spindle. (See Figs. 3, 4 and 6.)

The first polar body is almost always present with the secondary oöcyte in atretic follicles, although in a few instances the spindle has all the characteristics of a second polar spindle while the polar body is not to be seen. In such cases it is possible that the polar body has already degenerated and been absorbed, or as Kirkham suggests for normal oöcytes, it may have been "forced through the zona (pellucida) by the contraction of the latter under the influence of changing osmotic conditions" during fixation. In nearly every instance, however, the polar body is present, lying within the zona pellucida, and somewhat flattened between the oöcyte and the zona. The smaller dimension of the polar body is one half or two thirds of the larger, while the larger diameter itself is a fifth to a third that of the oöcyte. In a few cases the polar body contains a spindle more or less deranged and abnormal (see Fig. 3) but usually the chromosomes are scattered through it irregularly. They may be grouped in a few large irregular masses of chromatin or there may be a number of smaller chromosomes of abnormal size and shape. In a few cases a resting nucleus may be seen in the polar body (Fig. IO). The second polar spindle is usually found in the oöcyte near the polar body, at right angles to the radius of the egg-cell. Rarely it may be seen in the other side of the oöcyte, and a few spindles have been seen in a radial position. A few instances were observed where the oöcyte contained two spindles; this is probably due to the fact that the egg-cell had two nuclei to start with. 
Up to this point oöcytes in follicles undergoing follicular atresia have passed through the same stages, with some differences in detail, as normally maturing egg-cells. The later stages however are different. The next step in degeneration is the breaking down of the spindles. The usual course is for the oöcytes to form the second polar spindles which then break down; but if degeneration has proceeded a little more rapidly, this fate may overtake the first polar spindles before the polar body is formed.

As stated above, in the first polar spindle as well as in the second, the achromatic fibers are all intermingled, those with chromosomes attached and those without, and do not differ in appearance or staining reaction. The fibers with no chromosomes attached to them break across at their middle and the free ends move out in the cytoplasm. As the polar ends remain attached to the poles of the spindles, the formation of "asters" is brought about. Stages are seen (Figs. 5 and 6) in which the breaking or splitting off of the fibers is taking place; some of the fibers have just broken across, in the figures, and others have already assumed a radial position, giving the appearance of "asters." The achromatic fibers with chromosomes attached next break or split off, and as their free ends move out into the cytoplasm, they draw after them the attached chromosomes (see Fig. 7). In this way more fibers are added to the "asters" and chromosomes are seen connected with the ends of some of the fibers. This splitting off of the achromatic fibers explains the fact that some spindles have radiating fibers or "asters" at their poles, while in others they are absent. The oöcytes containing spindles without radiating fibers have not advanced so far in degeneration that the spindle fibers have begun to split off. The result of this splitting off of the fibers and the consequent breaking down of the spindles is that the chromosomes are scattered in all directions in the cytoplasm at each pole of the spindle, while still connected with the poles by the spindle fibers.

The cause of the breaking down of the spindles is to be found in the degeneration of the oöcyte. That this degeneration has proceeded to quite an extent is shown by the presence in the cytoplasm of fat-granules and crystalloid bodies, and by the 
fact that the cytoplasm stains much more deeply with acid stains such as eosin and orange $\mathrm{G}$ than does the cytoplasm of normal oöcytes. The spindle fibers share in this degeneration and show it first by breaking across and splitting off from the spindle. Rubaschkin states that as the fibers split off, the poles of the spindles approach each other and finally come to lie so close together that it is difficult or impossible to distinguish one from the other. While this account of the breaking down of the spindles agrees essentially with that of Rubaschkin for the guinea-pig, nothing resembling the approach of the poles of the spindles was observed in the mouse.

The achromatic fibers soon disappear and the chromosomes thus left free in the cytoplasm of the oöcyte begin to form nuclei. Each chromosome forms a small vesicle which has the appearance of a vacuole with the chromatin material massed at one side (Fig. I3). In some instances the chromatin is arranged in small granules around the outer part of the vesicle (Fig. 8). As this process goes on, the vesicles near enough together coalesce to form larger ones (Figs. 8, 9, II), while those isolated in the cytoplasm remain separate. In this way a varying number of nuclei are formed, of different sizes. A nucleus formed by the combining of a number of chromosomes is larger than one formed from a single chromosome. The final number of nuclei thus formed may be from two to twelve, depending on how the chromosomes were scattered in the oöcyte. These nuclei are transformed into resting nuclei of more or less normal appearance.

The nucleo-cytoplasmic relationship, already interfered with by the degenerative changes in the egg-cell, is further disturbed by this formation of a number of small nuclei. The size-relationship, as well as the morphological, physiological, and chemical, relationship, is clearly affected. Apparently there is an effort, even in the degenerating oöcyte, to restore as far as possible ihis size-relationship, and this effort is expressed by a breaking up of the cytoplasm into smaller parts around the various nuclei. A part of the cytoplasm may surround several of these small nuclei when these are close together, or may enclose only one, when they are isolated. It occasionally happens that a bit of the cytoplasm may fail to contain even one of these nuclei, when 
part of the egg-cell was without any nuclei as a result of an incomplete scattering of the chromosomes. The result of this breaking up of the oöcyte is that there are formed a number of small "cells," some with several nuclei, some with one, and some with none, so that the oöcyte has the appearance of a "morula." The fact that some "cells" have nuclei and others have not, is due to the uneven distribution of the chromosomes in the cytoplasm of the oöcyte when the spindle breaks down. In general, the "cells" containing large nuclei, or a group of nuclei, are larger than those with one nucleus or none. However, a definite or effective control over this fragmentation is apparently lacking.

Several authors, Newman among others, have described cells in this "morula" stage which have spindles in them, and state that these are cleavage spindles and that therefore this is a case of parthenogenetic cleavage. It is more probable, however that in such cases the cell containing the spindle is the first polar body, which, as noted above, occasionally forms a spindle, and which may in rare instances divide. In the white mouse no spindle was found in any of the cells of this "morula" stage.

In the cells of the "morula," and sometimes in the oöcyte before it has fragmented, are frequently found crystalloid bodies the nature and origin of which are unknown. Possibly they are a product of the degenerative changes in the egg-cell. Fat granules are found in the oöcytes in increasing numbers as degeneration goes on.

In a few instances the oöcyte is found to have formed two cells of nearly equal size, each containing a nucleus. Van der Stricht describes such cases in the bat and states that each cell may divide again, and each of the four cells thus formed may also divide. The formation of two such equal cells may be explained on the grounds that the scattered chromosomes were arranged in two groups and formed two nuclei; the oöcyte then broke up into two fragments of equal size. Such an egg-cell is shown in Fig. Io, with the first polar body also present; but the two nuclei are not equal in size, nor normal in appearance. In fact, one is apparently little more than a vacuole.

The fate of the "morula" may be briefly described. The zona pellucida usually persists as a thick transparent membrane 
for some time after the oöcyte itself has completely degenerated and disappeared, although in a few instances it is absorbed early. Phagocytic (?) cells make their way into the oöcyte through the zona pellucida, and are probably to be regarded as follicle cells from the degenerating follicle. These cells are usually seen in the outer border of the oöcyte, or just outside it, lining the inner surface of the zona pellucida, sometimes as early in the course of degeneration as the spindle stage. There are not many of these cells in a single oöcyte, not more than eight or ten and frequently no more than three or four. They may be imbedded in the cytoplasm of the egg-cell and in the "morula" stage are frequently seen in between the separate cells. One case is illustrated (Fig. I4) showing one of these extra-ovular cells just after it has entered the oöcyte, still retaining its connection with other follicle cells outside the egg-cell by means of a protoplasmic process extending through the zona pellucida. This same cell is also shown to be connected with one or two other similar cells within the zona by other protoplasmic processes, forming a sort of syncytial net-work or mesh-work in among the fragments of the degenerating egg-cell.

The cytoplasm of these cells is usually rather scanty and sometimes they look like bare nuclei imbedded in the cytoplasm of the oöcyte (Figs. 8 and 9). They are not, however, to be confused with the nuclei of the oöcyte formed by the breaking down of the spindle, for they react differently to the stains used and have a different structure. They are finely granular and these granules are stained an intense black by iron hematoxylin and deep blue by Jenner's stain.

It may be through the action of these cells that the fragments of the oöcyte are gradually absorbed and disappear, for later on the zona pellucida is seen, shrunken and distorted, with a few of these cells in a remnant of the egg-cell. In still later stages, these cells are seen alone inside the zona, and this condition may persist for some time (Fig. I6). Eventually the zona pellucida and these cells all disappear and by this time the follicle itself has usually completely degenerated.

Thus it is seen that the oöcytes in atretic follicles in the ovary of white mice not yet sexually mature undergo a series of changes 
which in the early stages at least resemble maturation. That these changes are in some way correlated with the atresia is shown by the fact that all the oöcytes exhibiting these phenomena are found in atretic follicles, and egg-cells of normal appearance are seen in the follicles not yet overtaken by atresia. The degeneration of the follicle stimulates the oöcyte to pass through a process which at first resembles maturation but which later results in a breaking up of the egg-cell into fragments, some with nuclei and some without. In the light of the evidence here presented, this process can not be considered parthenogenetic cleavage for no mitotic figures other than those of a more or less abnormal maturation were seen; and if this were true parthenogenetic cleavage it would be expected that some stages of mitosis would be observed. The absence of mitotic figures other than more or less normal polar spindles, the breaking down of these spindles, the scattering of the chromosomes, the formation of nuclei from these chromosomes, and the consequent breaking up of the egg-cell into small parts, with or without nuclei, show rather conclusively that in the white mouse, not yet sexually mature, the process is one of degenerative fragmentation.

\section{SUMMARY.}

The spindles seen in oöcytes in follicles undergoing atresia folliculi are maturation spindles, more or less abnormal, and not cleavage spindles.

By the splitting off of the achromatic fibers and the consequent breaking down of these spindles the chromosomes are scattered through the cytoplasm of the oöcyte and form a number of nuclei.

The nucleo-cytoplasmic relationship, disturbed by the degenerative changes in follicle and egg-cell, causes the oöcyte to break up into fragments, some with one or more nuclei and some with none. These fragments are gradually absorbed, probably through the action of phagocytic cells of follicular origin, and disappear.

The process is one of degenerative fragmentation and not parthenogenetic cleavage. 
Athias, M.

\section{BIBLIOGRAPHY.}

'og Les phénomènes de division de l'ovule dans les follicules de De Graaf en voie d'atrésie chez le Lérot. Anat. Anz., Bd. 34, pp. I-23.

Bonnet, R.

'99 Giebt es bei Wirbeltieren Parthenogenesis? Erg. Anat. u. Ent., Bd. 9, pp. $820-870$.

\section{Flemming, W.}

'85 Über die Bildung von Richtungsfiguren in Säugerthiereiern beim Untergang Graaf'scher Follikel. Arch. f. Anat. u. Phys., I885, p. 22 I-244.

\section{Kirkham, W. B.}

'o8 Maturation of the egg of the white mouse. Trans. Conn. Acad., Vol. I3, pp. $65-87$.

Lams, H. et Doorme, J.

'o8 Nouvelles recherches sur la maturation et la fécondation de l'oeuf des mammifères. Arch. de Biol., T. 23, pp. 259-365.

\section{Newman, H. H.}

'I3 Parthenogenetic cleavage of the armadillo ovum. Biol. Bull., Vol. 25, pp. $54-78$.

Rubaschkin, W.

'o6 Über die Veränderungen der Eier in den zugrunde gehenden Graafschen Follikeln. Anat. Hefte., Bd. 32, H. 97, pp. 255-278.

\section{Sobotta, J.}

'07 Die Bildung der Richtungskörper bei der Maus. Anat. Hefte., Bd. 35, Bd. 35, H. I06, pp. 493-552.

Spuler, A.

'or Über die Teilungserscheinungen der Eizellen in degenerierenden Follikeln des Säugerovariums. Anat. Hefte., Bd. I6, H. 5I, pp. 85-II4.

\section{Van der Stricht, O.}

'or L'atrésie ovulaire et l'atrésie folliculaire du follicule de De Graaf dans l'ovaire de Chauve-souris. Verhandl. d. anat. Gesellsch. I5. Versamml. Bonn., I901, p. I08-I2I. (Anat. Anz. Ergänz. z. Bd. I9, pp. Io8-I2I.) 


\section{EXPLANATION OF PLATES.}

All the figures are camera-lucida drawings made from the actual preparations. All the drawings except Figs. 3, 7, and I4, were made by Miss Cora J. Whitman.

\section{Plate I.}

FIG. I. Primary öocyte, containing a first polar spindle. The chromosomes are longer and more slender than usual in first polar spindles. The zona pelludica is seen surrounding the egg-cell (zp.). $\times 670$.

FIG. 2. Primary oöcyte containing a first polar spindle, of the "barrel-shaped" type. The chromosomes are of the type usual for this spindle. The zona pellucida has disappeared. $\times 670$.

FIG. 3. Secondary oöcyte, with second polar spindle and polar body which also contains a spindle more or less deranged. Some of the chromosomes of the egg spindle have been omitted from the drawing in order to show more clearly the characteristic shape of the chromosomes of the second polar spindle. $\times 670$.

FIG. 4. Secondary oöcyte, with second polar spindle and polar body. Centrosomes are seen at each end of the spindle. $\times 9$ i 6 . 


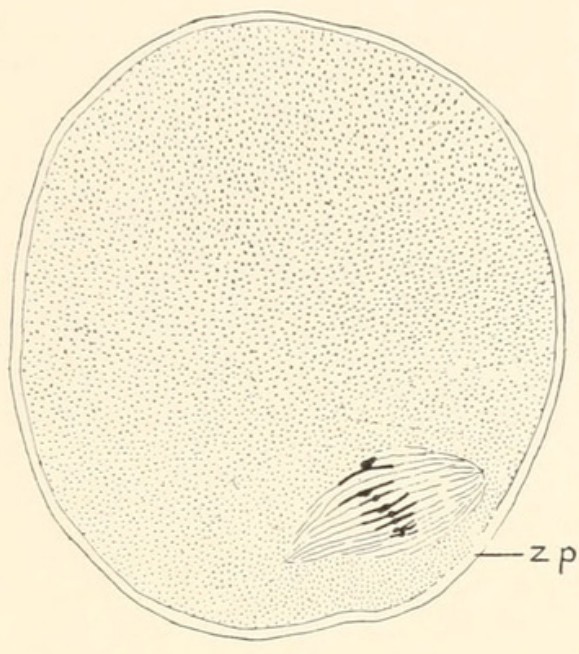

Fig 1

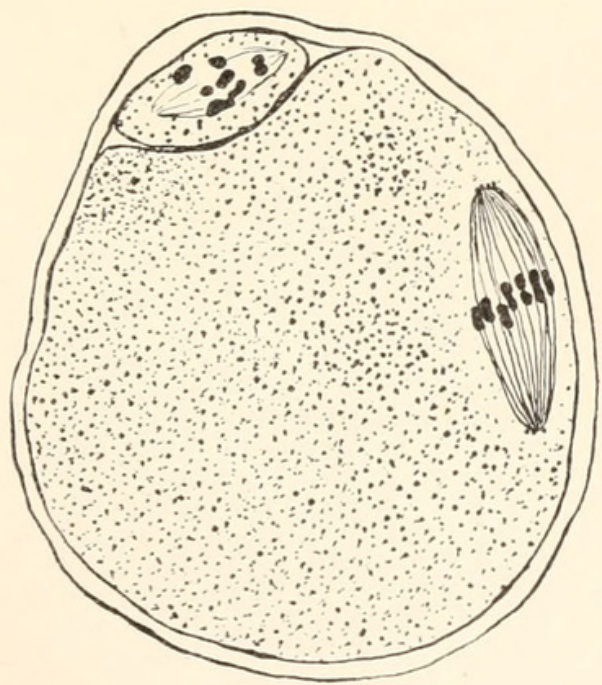

Fig 3

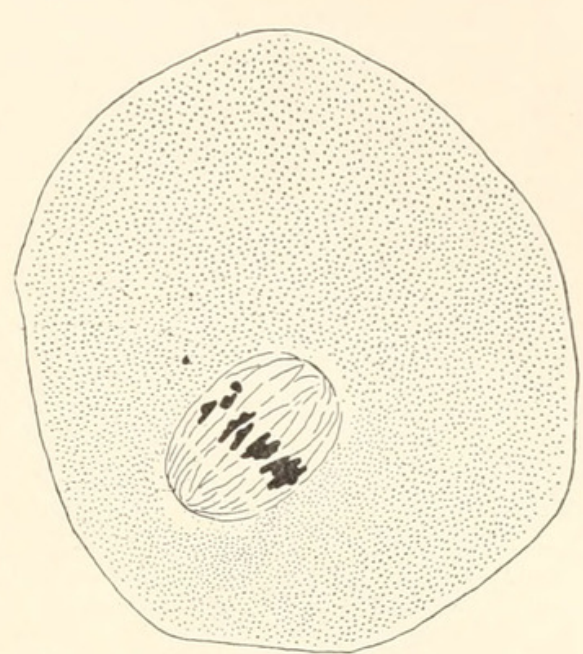

Fig 2

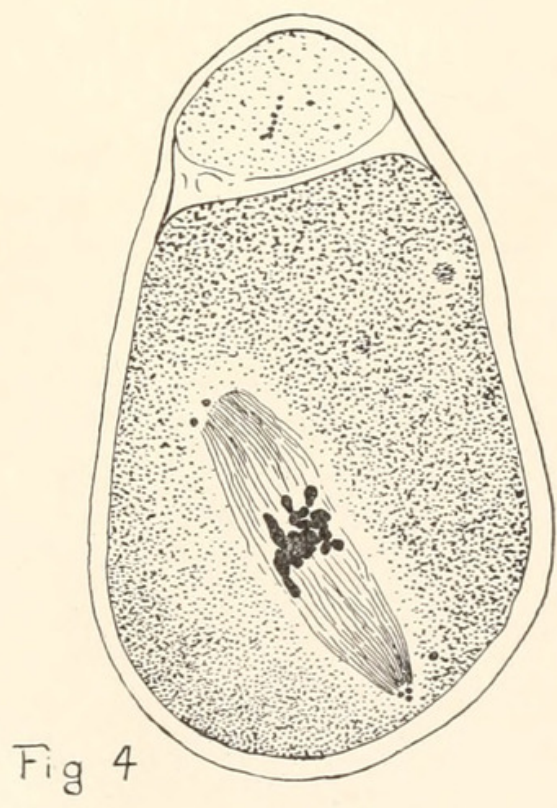

H. M. KINGERY. 




\section{Plate II.}

FIG. 5. First polar spindle alone, showing achromatic fibers splitting off, forming "asters." $\times 9$ I6.

FIG. 6. Second polar spindle alone, showing well-defined "asters," formed by fibers which have split off from the spindle. $\times 9$ r6.

FIG. 7. Primary oöcyte showing spindle seen obliquely from one end, which has broken down. The scattering of the chromosomes is partially accomplished. $\times 670$.

FIG. 8. Egg-cell with nuclei formed from scattered chromosomes. The bodies at the end of the oöcyte $(x)$ are probably cells formed by the division of the polar body. A crystalloid body $(c)$ and an extra-ovular cell $(p)$ are also shown. $\quad \times 670$. 
Bological BULLETIN, VOL. XXVII.

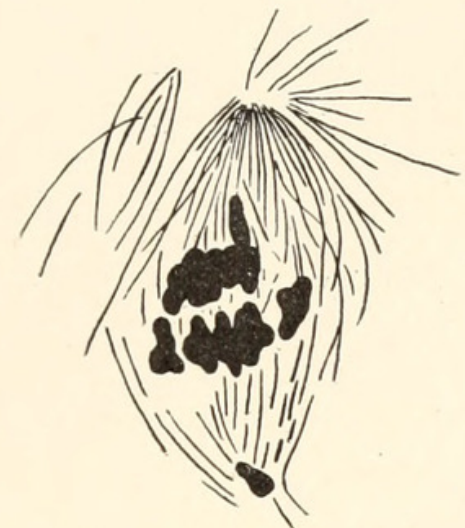

Fig 5

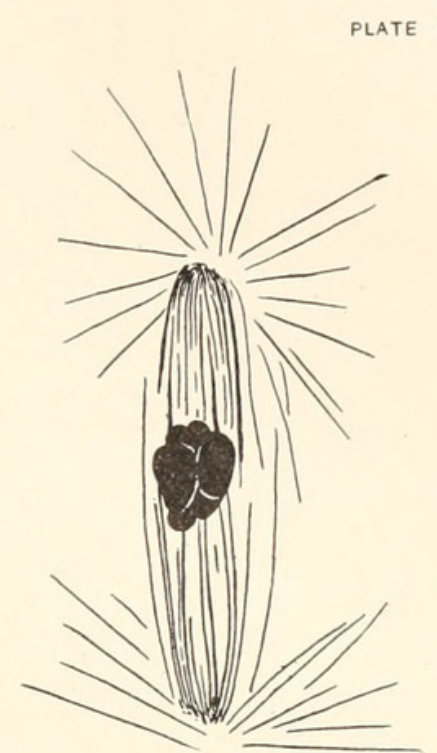

Fig 6

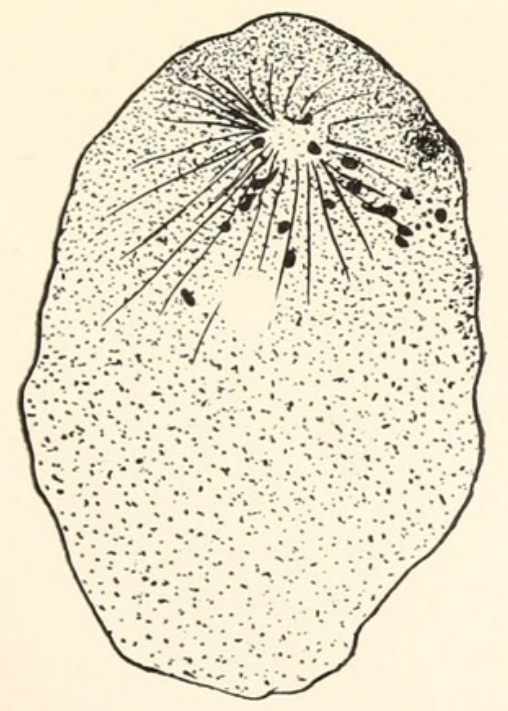

Fig. 7.

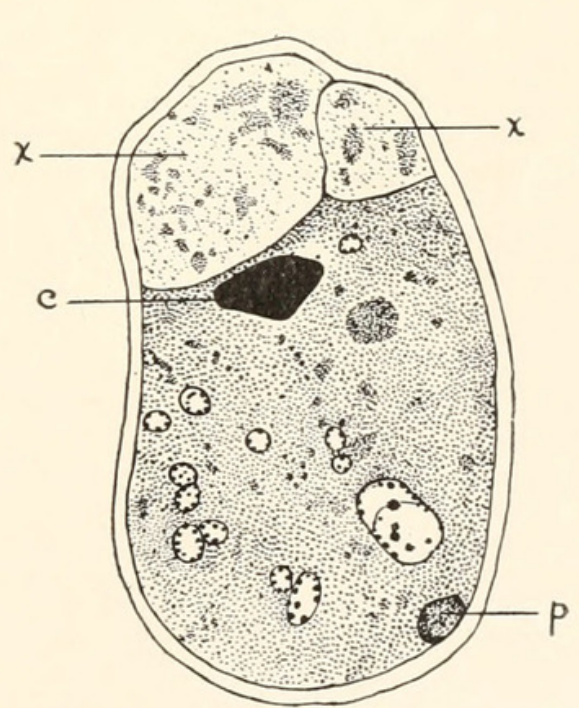

$\operatorname{lig} 8$.

H. M. KINGERY 




\section{Plate III.}

FIG. 9. Egg-cell containing four nuclei; these, from their size, have been formed by the coalescence of a number of smaller vesicles. Two extra-ovular cells $(p)$ are shown. $\quad \times 670$.

FIG. Io. Oöcyte divided into two more or less equal parts, with polar body also present $(p b)$. The nuclei are not alike, one being apparently only a hollow vesicle. $\times 670$.

FIG. II. Egg-cell in several fragments, one of which contains five nuclei. The zona pellucida is broken in two places and extra-ovular cells are present between the fragments. $\times 670$.

FIG. I2. "Morula" stage, some fragments with nuclei and others without. $\times 670$. 


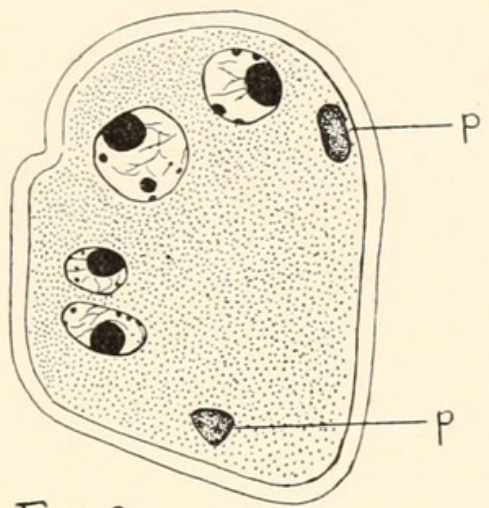

Fig 9

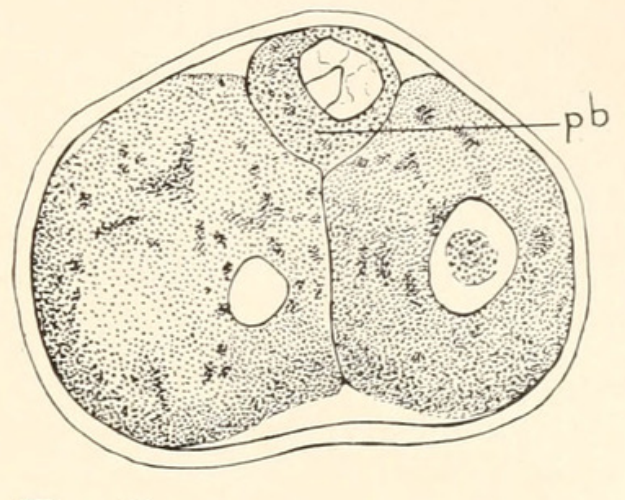

Fig. 10

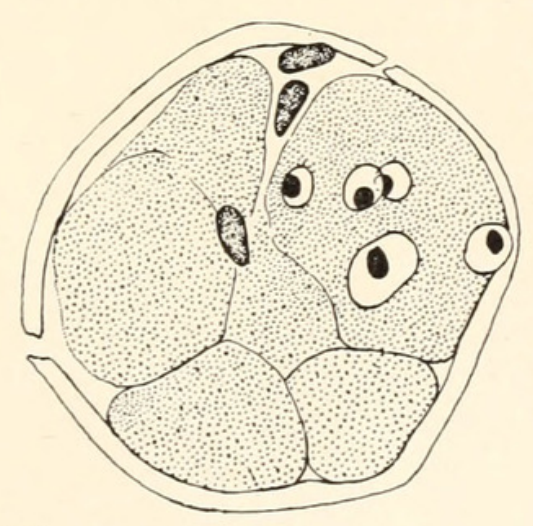

Fig 11

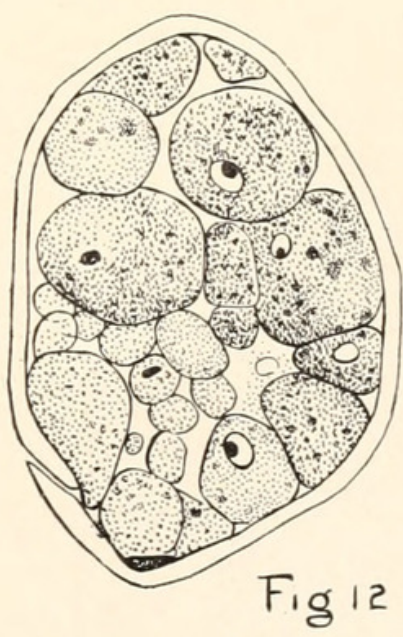

H. M. KINGERY 


Plate IV.

FIG. I3. Egg-cell showing small nuclei formed from the scattered chromosomes. The chromatin material is massed at one side of each of the vesicles. $\times 670$.

FIG. I4. Egg-cell containing extra-ovular cells connected by protoplasmic processes. One is still connected with the follicle cells outside by a process extending through the zona pellucida. $\times 670$.

FIGs. I5 AND I6. Final stages in degeneration. Zona pelludica with remnant of oöcyte and a few extra-ovular ceils inside. $\times 670$. 
BIOLOGICAL BULLETIN, VOL. XXVII.

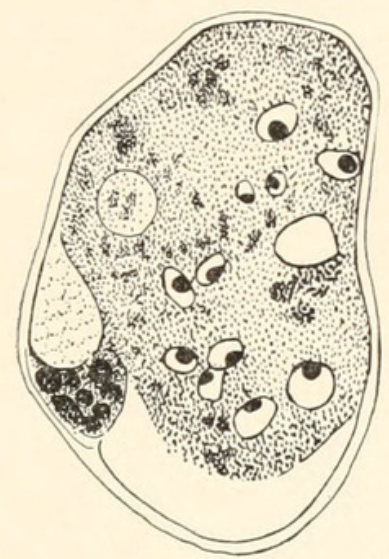

Fig. 13

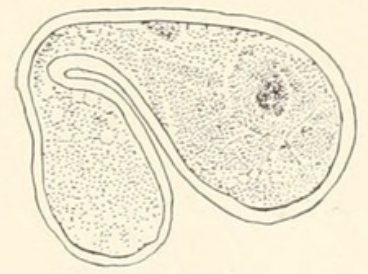

Fig 15

H. M. KINGERY
PLATR IV.

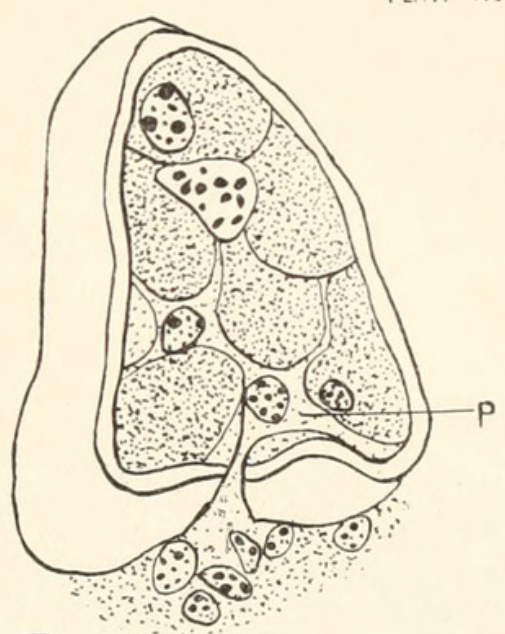

Fig 14

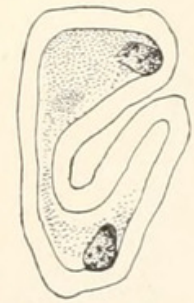

Fig. 16 



\section{A MILKY WHITE AMPHIBIAN EGG JELL.}

ARTHUR M. BANTA AND ROSS AIKEN GORTNER.

While collecting Ambystoma punctatum eggs in April, I9I4, the writers found a freshly-laid bunch which had jell of milky whiteness instead of being transparent. The white clutch of eggs was conspicuous among the others even though the jell had as yet swelled very little and the bunch was quite small. The eggs were still undivided. They had the normal amount of pigment. The jell was so clouded that at first no eggs could be seen in the mass without breaking into the jell. The jell imbibed water and the egg bunch soon assumed the normal proportions for the

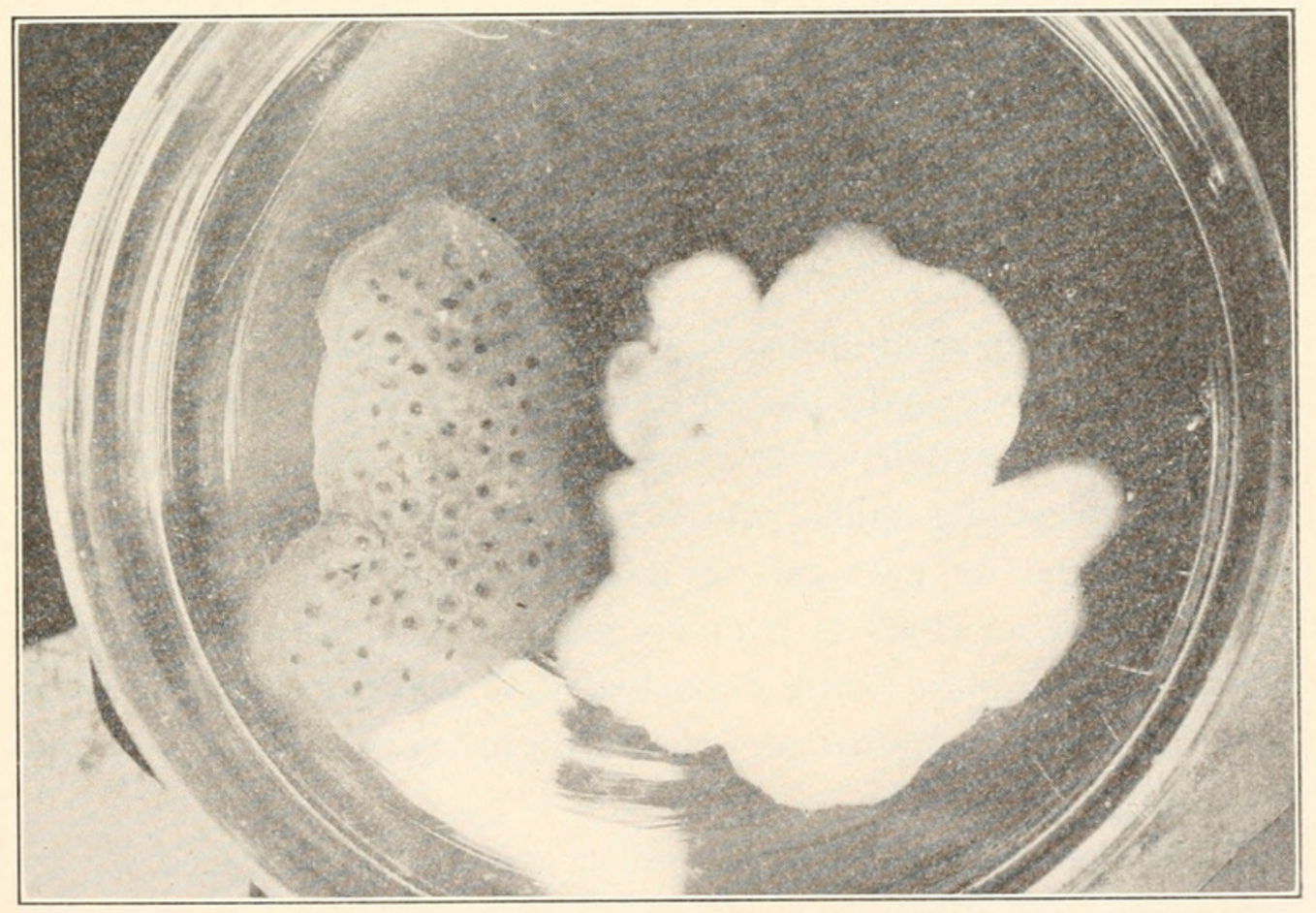

clutch of this species. The photograph shows the relativeopacity of the white bunch and a normal bunch of eggs of the same age. Only a few eggs were visible in the opaque bunch when the photograph was taken while one could readily see the bottom of the dish through the jell of the normal bunch. The individual outer and inner egg membranes in the white bunch were of normal transparency. This is indicated indistinctly 
in the photograph by the somewhat more transparent spots, in which were eggs, near the edges of the white bunch.

When just ready to hatch the embryos with their egg membranes were removed from the jell, care being taken to remove all traces of eggs which had died during development. The water was carefully drained off and the jell was dried in a porcelain dish over a water bath. The jell from a normal egg bunch of the same stage of development was treated in a similar manner. After drying on the water bath the jell was further desiccated in a vacuum desiccator over sulfuric acid.

233 grams of normal egg jell yielded 0.7855 grams or 0.337 per cent. of dry material.

294 grams of the opaque jell yielded I.060 grams or 0.36I per cent. of dry material.

It thus appears that the jell which normally surrounds these eggs contains about 99.6 per cent. of water and yet this jell is fairly tough and resistant and admirably suited to supporting the eggs in such a position as to permit ready diffusion of oxygen and carbon dioxide and to protect the eggs from mechanical injury.

The two jells when desiccated were indistinguishable. A portion of each was again placed in water and in a short time they had imbibed enough water to resume their former appearance, the one becoming milky white and the other transparent. It may ferhaps be germane to add that the milky appearance could not be ascribed to bacteria inasmuch as the egg mass was found shortly after being deposited and also because there was no evidence of bacterial decomposition up to the time the drying was begun.

Thinking that perhaps the milky color was produced by an admixture of albumen with the mucin (which composes the normal egg jell) nitrogen determinations were made of both abnormal and normal egg jells.

The nitrogen was determined by Kjeldahl's method.

Normal egg jell.-0.2060 gram gave I2.3 c.c. O.I normal $\mathrm{NH}_{4} \mathrm{OH} ; 0.3564$ gram gave 2 I. I c.c. o. I normal $\mathrm{NH}_{4} \mathrm{OH}$, indicating 8.36 per cent. and 8.29 per cent. respectively or an average of 8.32 per cent. of nitrogen in the normal egg jell. 
Opaque egg jell.-0.2764 gram gave 18.3 c.c. o.I normal $\mathrm{NH}_{4} \mathrm{OH} ; 0.3540$ gram gave 23.0 c.c. o.I normal $\mathrm{NH}_{4} \mathrm{OH}$, indicating 9.27 per cent. and 9.09 per cent. respect vely or an average of 9.I 8 per cent. of nitrogen in the opaque egg jell.

Almost no chemical work has been done with the amphibian egg jells aside from the observation that the nitrogen content is low due to the presence of a carbohydrate nucleus. Of course the above results do not give the true nitrogen content of the egg jell for they should have been corrected for ash content, but this was not possible due to lack of material. The figures do show, however, that the jells differ chemically as well as in appearance, and that the difference in nitrogen content is in the same direction and of almost precisely the same amount that it would be if the opaque appearance were produced by an admixture of albumen (nitrogen $=I 5$ per cent. $-\mathrm{I} 6$ per cent.) with the normally occurring mucins.

Station for Experimental Evolution, August I7, I9I4. 


\section{THE RELATION OF THE BODY TEMPERATURE OF THE EARTHWORM TO THAT OF ITS ENVIRONMENT.}

\section{CHARLES G. ROGERS AND ELSIE M. LEWIS. ${ }^{1}$}

In a paper by one of us upon the "Temperature Coefficient of the Rate of Heart Beat in Certain Living Animals"'2 the assumption was made that the temperature of the living animal (worm or fish-embryo) under observation corresponded very closely to that of the water surrounding it. The same assumption has been made by other workers in this field, $e . g$., Snyder ${ }^{3}$ in his work upon the isolated heart of the Pacific terrapin assumed that the temperature of the more or less bulky heart muscle of the terrapin was conditioned by the temperature of the solution in which it was placed. Robertson ${ }^{4}$ also in his work upon Ceriodaphnia assumed that the temperature of the water definitely represented the temperature of the tissues with which he was particularly concerned. Even more recently Loeb and Ewald ${ }^{5}$ make use of the same assumption.

There are to be found in the literature of physiology statements concerning the body temperatures of the so-called coldblooded animals, and an examination of the data offered reveals the fact that the various investigators who have taken the trouble to make any examination of the actual conditions find that the temperatures of the animals studied vary considerably from the temperatures of the surroundings. It is also true that many

${ }^{1}$ From the Department of Zoology, Oberlin College.

${ }^{2}$ Rogers, Charles G., "Studies upon the Temperature Coefficient of the Rate of Heart Beat in Certain Living Animals," American Journal of Physiology, I9II, Vol. 28 , No. II., pages $8 \mathrm{I}-93$.

${ }^{3}$ Snyder, C. D., "On the Influence of Temperature Upon Cardiac Contraction and Its Relation to Influence of Temperature upon Chemical Reaction Velocity," University of California Publications, Physiology, Vol. 2, No. I5, I905.

${ }^{4}$ Robertson, T. B., "Note on the Influence of Temperature Upon the Rate of the Heart Beat in a Crustacean (Ceriodaphnia)," Biological Bulletin, igo6, Vol. X., No. 5, pp. $242-248$.

${ }^{5}$ Loeb, Jacques and Ewald, W. F., “ Die Frequenz der Herztätigkeit als eindeutige Funktion der Temperatur," Biochemische Zeitschrift, I9I3, Bd. 58, H 3, I77-I85. 
of the observations recorded were made by means of mercurial thermometers, though some were made by thermocouples with galvanometers. In reading the statements of the different investigators one is left with the feeling that with the more improved appliances of the present day one ought to be able to make observations which would be more satisfactory than those published. The following table summarizes the results of a number of investigators, and is compiled from data quoted by Milne-Edwards. ${ }^{1}$

Animal.

Fishes............. less than $\mathrm{I}^{\circ} \mathrm{C}$. above surrounding water

Frog . . . . . . . . . . $0^{\circ} \cdot 32-2^{\circ} \cdot 44$

Frog . . . . . . . . . . . $0^{\circ} \cdot 0-0^{\circ} \cdot 575$

Frog . . . . . . . . . . . . $0^{\circ} \cdot 04$

Toad .................. $0^{\circ} \cdot 2$

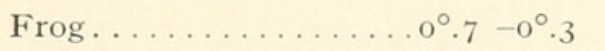

Proteus................. $\mathrm{I}^{\circ} \cdot 25$

Proteus................ $2^{\circ} .6-5^{\circ} .6$

Crayfish............6. $6^{\circ} .0$

Maia sq. . . . . . . . $0^{\circ} \cdot 3-0^{\circ} \cdot 9$

$\operatorname{Limax} \ldots \ldots \ldots \ldots \ldots 0^{\circ} \cdot 33^{-0^{\circ}} \cdot 50$

Snail............... $2^{\circ} .0$

Snail............. I ${ }^{\circ}$.

Snail.............. $0^{\circ} \cdot 9$

Snail. . . . . . . . . . I ${ }^{\circ} \cdot 5-2^{\circ} .0$

Aplysia ............ $0^{\circ}$. I $-0^{\circ} .8$

Octopus ............... . . $0^{\circ}-0^{\circ} .6$

Eledone............... $0^{\circ} \cdot 9$

Annelids............. $0^{\circ} \cdot 56-0^{\circ} \cdot 85$

Lumbricus.............. $\mathrm{I}^{\circ} \cdot \mathrm{I} \mathrm{I}-\mathrm{I}^{\circ} \cdot 39$

Holothuria . . . . . . . . $0^{\circ} .2-0^{\circ} .6$

Ophiurian. . . . . . . . $0^{\circ} \cdot 3$

Asterias ru. . . . . . . . . $0^{\circ} .6$

Sea Urchin. . . . . . . . $0^{\circ} .4-0^{\circ} .5$

Medusa Pelagia.......... $0^{\circ} .2-\mathrm{I}^{\circ} . \mathrm{O}$

Medusa Cassiopea......... $0^{\circ} \cdot 3$

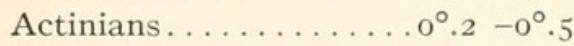

Authority.

Milne-Edwards

Czermak

Becquerel

Dutrochet

Dumeril

Rudolphi

Czermak

Rudolphi

Valentin

Spallanzani

Hunter

Martine

Becquerel

Schnetzler

Valentin

“.

Hunter

Valentin

“.

,

“

“.

“

“

In the table it will be noted that the temperatures determined for the different animals show, for the most part, rather small variations from that of the surrounding water. In a few cases the variation is quite considerable, and appears to make desirable a reëxamination of the facts. This is especially true in view of

${ }^{1}$ Milne-Edwards, “Leçons sur la Physiologie et L'Anatomie Comparée de L'Homme et des Animaux," T. VIII., Paris, I863. 
the fact that certain scientific friends have raised question as to the validity of the assumption upon which the temperature coefficient work was based. It is with an idea of attempting to answer any questions as to the propriety of assuming that the temperature of the earthworm is represented by the temperature of the surroundings, that the present investigation is here reported.

\section{Methods.}

A method of measuring differences of temperature by means of the electromotive force developed when the junctions of wires of different metals of a common circuit are not at the same temperature was described by Nobili and Melloni ${ }^{1}$ about ${ }^{8} 830$. Since that time galvanometers have been made more sensitive, and it has also been made possible to obtain pure metallic wires of small diameter, and of small heat capacity. The authors named were the first to apply this method of temperature measurement to living animals, and now that the methods of use have been somewhat improved the same method has been employed for the measurement of the amount of heat given off in a given contraction of a frog muscle. ${ }^{2}$ The method can be made accurate enough to measure differences as small as $\mathrm{I} / \mathrm{I}_{50^{\circ}} \mathrm{C}$. For the purpose of the investigation here reported it did not seem necessary to make measurements as small as those recorded by Hill, so the number of junctions of the wires was not at all increased. The thermo-couples used consisted of No. 32 copper and No. 32 constantan wires joined together as shown in Fig. I. In some of the couples the wires were simply twisted together and in others the junction was made secure by a small drop of solder. We were not able to determine that for our purpose the soldered junctions were any more efficient than those not soldered. The junction used within the body of the worm was mounted within a slender glass tube in such a way as to have the two wires of the couple thoroughly insulated from each other except at the junction point (Fig. 2). This was accomplished by placing

\footnotetext{
${ }^{1}$ Nobili et Melloni, “'Recherches sur plusiers phenomenes calorifiques enterprises au moyen du thermo-multiplcaiteur," Ann. de chimie et de physique, I83I, T. XLVIII., p. 208.

${ }^{2}$ Hill, A. V., “The Energy Degraded in the Recovery Process of Stimulated Muscles," Journal of Physiology, I913, Vol. 46, pp. 28-80.
} 
one of the wires in a finely drawn glass tube, allowing the end of the wire to extend slightly below the end of the tube, where it was twisted together with the other wire of the couple. The small glass tube with the two wires was then placed inside another glass tube of a diameter just sufficient to receive them easily. The glass of the outer tube was then sealed over the junction of the wires, and the whole bent into a convenient form for handling. The upper open ends of the tubes were sealed with wax to prevent the access of any water and the apparatus was ready for use.

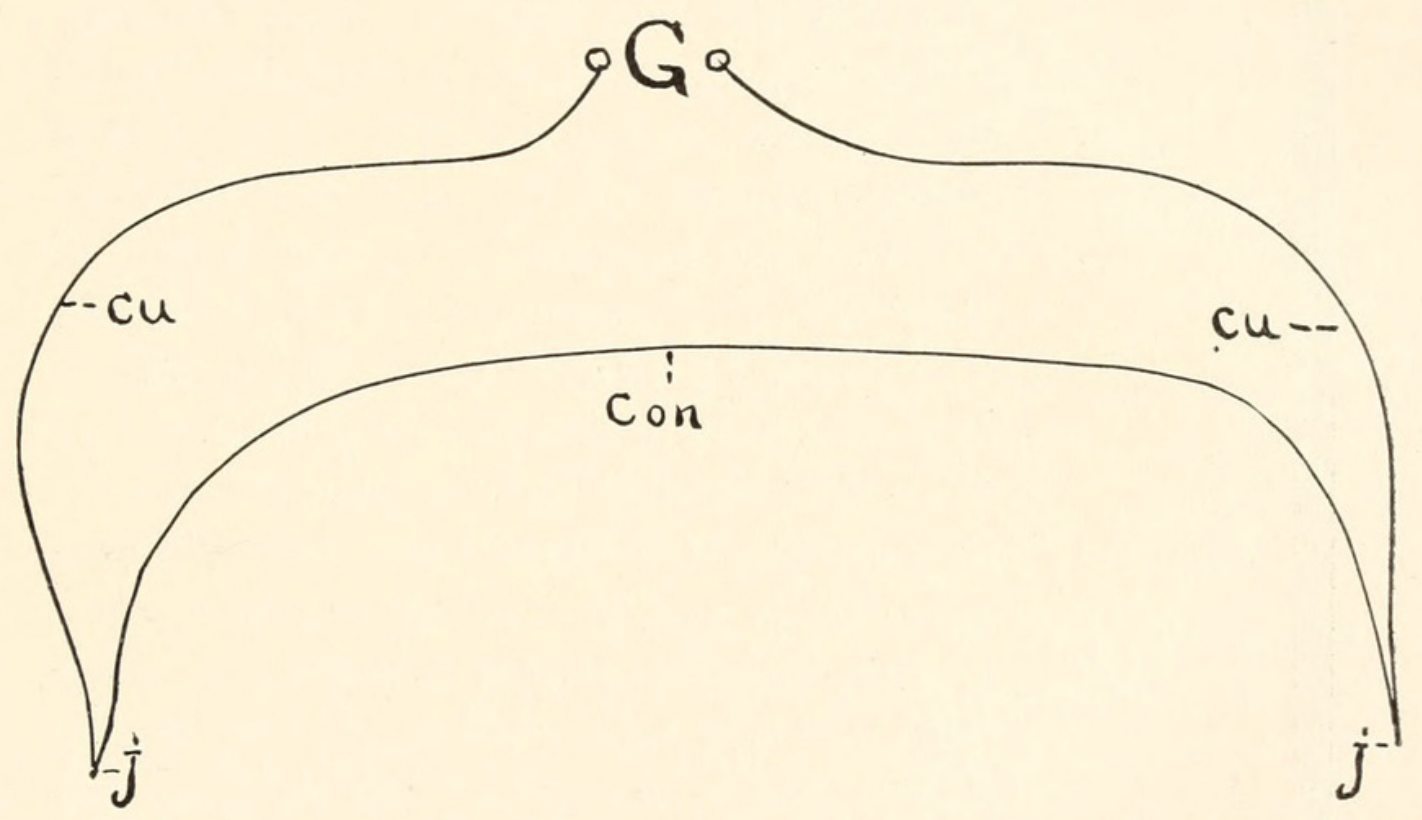

FIG. I. Diagrammatic scheme of thermocouple. $G=$ galvanometer; $c u=$ copper wire; $c o n=$ constantan wire $j=$ junction.

The galvanometer used in this work was one of the D'Arsonval type made by Gaertner. It was provided with a dead beat coil, and was so heavily damped that it was found desirable to allow two or three minutes for the galvanometer mirror to come to rest when making observations. It was found that with the scale at about $\mathrm{I}$ meter distance $\mathrm{I}^{\circ} \mathrm{C}$. difference in the temperature of the two junctions of the thermo-couple was represented by a shifting of the reading of the galvanometer scale by about i6 millimeters. The actual amount of shift varied somewhat from day to day from this value, and was re-determined for each day's work.

The technic of determining the temperature of the interior of 
the worm was very simple. It consisted in placing the glasscovered junction of the thermocouple in the mouth of the worm,

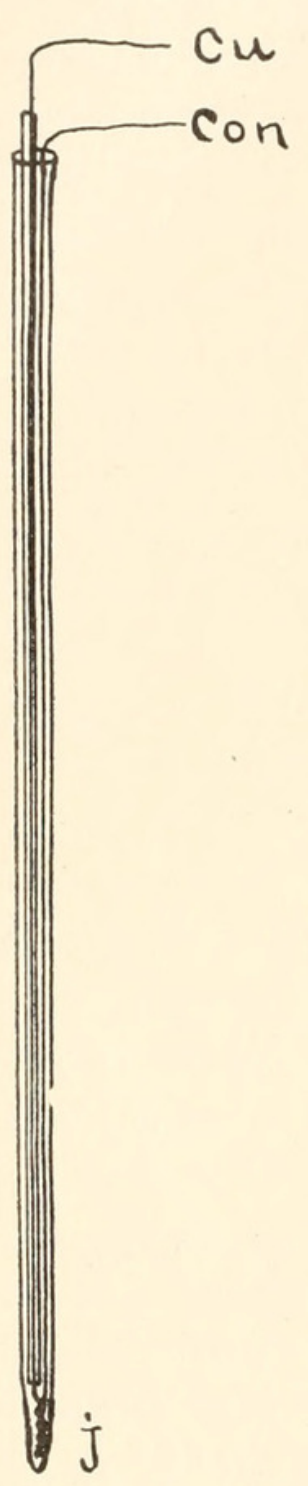

FIG. 2. Sketch of thermo-electric clinical thermometer for use with the earth-worm. $c u=$ copper wire; $c 0 n=$ constantan wire; $j=$ junction. and carefully pushing it down through the œsophagus, crop and gizzard until it came to lie in the stomach intestine. The other junction of the couple was placed in water of a known temperature, and the two end wires of the thermocouple were attached to the galvanometer. The temperature of the water in which the free junction of the thermocouple was placed was determined by a Beckman thermometer which had been set to a definite reading by the side of a certified standard thermometer. The temperature of the water was determined to $\mathrm{I} / \mathrm{I} 00^{\circ} \mathrm{C}$., and was noted for every observation so that in case of any variation in the temperature of the water we should be able to make the necessary correction in the results. The temperature of the worm was shown by the amount of the deviation of the galvanometer reading, from the zero reading, divided by the number of millimeters representing $\mathrm{I}^{\circ} \mathrm{C}$., and adding this amount to the known temperature of the water. In this way we were able to make readings which could be accepted as accurate to within $0.03^{\circ} \mathrm{C}$., which for our purpose seemed to be sufficient.

The following table gives data derived from three experiments to show how closely and how rapidly the temperature of the worm becomes adjusted to the temperature of the water in which it is immersed. We have not thought it necessary to multiply examples as all the facts observed are in perfect harmony with those offered. In the experiments here cited both the worm and the free junction of the couple were placed in the same bath. The difference between the zero and in-circuit readings of the 
galvanometer would then indicate the difference in temperature between the temperature of the water and the interior temperature of the worm if any such difference exists. After each reading the worm and free junction of the couple were placed in the water of the temperature indicated for the next following reading.

\begin{tabular}{|c|c|c|c|c|c|}
\hline Time. & $\begin{array}{c}\text { Temp, of } \\
\text { Water in Which } \\
\text { Worms Were } \\
\text { Placed. }\end{array}$ & $\begin{array}{l}\text { Zero Reading } \\
\text { of Galvanou- } \\
\text { eter. }\end{array}$ & $\begin{array}{l}\text { Galvanometer } \\
\text { Reading Couple } \\
\text { in Circuit. }\end{array}$ & $\begin{array}{l}\text { Difference in } \\
\text { Millimeters. }\end{array}$ & $\begin{array}{l}\text { Temperature } \\
\text { of Worm. }\end{array}$ \\
\hline $\begin{array}{r}9.40 \\
10.10\end{array}$ & $\begin{array}{l}\text { II. } 40^{\circ} \mathrm{C} . \\
2 \mathrm{I} .30^{\circ}\end{array}$ & $\begin{array}{l}345 \\
345\end{array}$ & $\begin{array}{l}345 \\
345\end{array}$ & $\begin{array}{l}000 \\
000\end{array}$ & $\begin{array}{l}\text { II. } 40^{\circ} \mathrm{C} . \\
2 \mathrm{I} .30\end{array}$ \\
\hline B. 9.00 & 21.24 & 403 & & & \\
\hline 9.I 7 & 21.24 & 403 & 402 & OOI & 21.30 \\
\hline 9.25 & I0.0O & 403 & 403 & 000 & I0.00 \\
\hline $9 \cdot 35$ & 21.20 & & & & \\
\hline $\begin{array}{l}9.40 \\
9.55\end{array}$ & $\begin{array}{l}21.20 \\
13.00\end{array}$ & $\begin{array}{l}408 \\
408\end{array}$ & 408 & 000 & $2 \mathrm{I} .2 \mathrm{O}$ \\
\hline I0.00 & $\mathrm{I} 3.00$ & 408 & 408 & 000 & I 3.00 \\
\hline "C. 10.30 & $2 \mathrm{I} .20$ & 403 & 404 & OOI & 2I.I 4 \\
\hline 10.40 & I 7.00 & 403 & 404 & OOI & I 7.94 \\
\hline I 0.45 & 21.20 & 403 & 404 & OOI & $2 \mathrm{I} . \mathrm{I} 4$ \\
\hline
\end{tabular}

The above data are representative of a large number of observations made during an investigation upon the effect of temperature changes upon the rate of contraction of the dorsal blood vessel of the earthworm, Lumbricus agricola, and indicate very clearly that the animal under investigation adapts itself with remarkable quickness and closeness to the temperature of its environment. In fact we think it may safely be said that the worm will adapt itself to a change of at least ten degrees Centigrade within two minutes, to an accuracy of $0.05^{\circ} \mathrm{C}$. This fact makes it possible then to use the temperature of the water surrounding the animal as an indicator of the temperature of the animal, in the case of the earthworm, for experiments upon the temperature coefficient of heart action, and assures us that the worm need not be subjected to a bath of a given temperature for any great length of time in order to get an accurate result. It is very likely true that the same principle will be found to hold good for other animals of a similar kind and habit, certainly for marine worms, fish embryos, small crustacea, etc. It is the purpose of the authors to continue the investigation upon other 
forms in order to determine to what extent we may be at liberty to assume the temperature of the surrounding fluid to be an indicator of the temperature of the tissues.

Hill, A. V.

\section{BIBLIOGRAPHY.}

'I3 The Energy Degraded in the Recovery Processes of Stimulated Muscles. Journal of Physiology, Vol. 46, pp. 28-80.

Loeb, Jacques and Ewald, W. F.

'I3 Die Frequenze der Herztätigkeit als eindeutige Funktion der Temperatur. Biochemisches Zeitschrift, Bd. 58, H. 3, I 77-I 85 .

\section{Milne-Edwards.}

'63 Lecons sur la Physiologie et L'Anatomie Comparee de L'Homme et des Animaux, T. VIII., Paris.

\section{Nobili et Melloni.}

'3I Recherches sur plusiers phenomenes calorifiques enterprises au moyen du thermo-multiplicateur. Ann. de Chimie et de Physique, T. 48, p. 208.

\section{Robertson, T. B.}

'o6 Note on the Influence of Temperature Upon the Rate of Heart Beat in a Crustacean (Ceriodaphnia). Biological Bullitin, Vol. X, p. 242.

\section{Rogers, Charles G.}

'I I Studies upon the Temperature Coefficients of the Rate of Heart Beat in Certain Living Animals. American Journal of Physiology, I9I I, Vol. 28, pp. $8 \mathrm{I}-93$.

\section{Snyder, Charles D.}

'o5 On the Influence of Temperature upon Cardiac Contraction and its Relation to Influence of Temperature upon Chemical Reaction Velocity. University of California Publications, Vol. 2, No. I5, pp. I25-146. 


\title{
THE TEMPERATURE COEFFICIENT OF THE RATE OF CONTRACTION OF THE DORSAL BLOOD- VESSEL OF THE EARTHWORM.
}

\author{
CHARLES G. ROGERS AND ELSIE M. LEWIS. ${ }^{1}$
}

Certain unpublished criticisms of a previous paper of the senior author ${ }^{2}$ have led us to make a further investigation of the effects of changes of temperature upon the rate of contraction of the dorsal blood vessel of the earthworm. The criticism offered against the previous work was that no evidence was presented to show that the temperature of the forms studied, worms and fish-embryos, was the same as that of the water in which they were immersed. The force of the criticism is recognized, and we are now able to present the results of an investigation in which the temperature of the worm studied was determined by means of a delicate clinical thermometer inserted in the long, tubular, alimentary canal of the worm.

We are now publishing under another title ${ }^{3}$ an account of the work in which it is shown that the temperature of the surrounding water does furnish an excellent indicator of the inner body temperature of the earthworm, when this animal is immersed in water for experimental purposes. Inasmuch as this is true we have no doubt that the previous work upon Nereis, Tubifex, and the embryos of Fundulus and the toad-fish will bear the same sort of inspection.

We will not at this time take up any discussion of the literature of the subject. The papers of Snyder, Robertson, Loeb and Ewald and others are available for examination. The formula employed for the computation of the temperature coefficients

${ }^{1}$ From the Department of Zoo'ogy, Oberlin College.

${ }^{2}$ Rogers, Charles G., "'Studies Upon the Temperature Coefficient of the Rate of Heart Beat in Certain Living Animals," American Journal of Physiology, I9I I, Vol. XXVII., pp. 8I-93.

${ }^{3}$ Rogers, Charles G., and Lewis, Elsie M., " The Relation of the Body Temperature of the Earthworm to that of its Surroundings," Biological Bulletin, I9i4, Vol. XXVII., pp. 26I-267. 
is the one used by Snyder in all his work, and concerning which he has presented some matters of historical interest, ${ }^{1}$

$$
Q_{0}=\left(\frac{K_{1}}{K_{0}}\right)^{\frac{10}{T_{1}-T_{0}}}
$$

The material used in this study was the large earthworm, Lumbricus agricola. This form presents two desirable features for this work; Ist, the animals are not by nature restricted to any definite or narrow limits of temperature at which their normal physiological processes take place; and $2 \mathrm{~d}$, it is well adapted structurally for the work in that it is easily possible to place a delicate temperature measuring apparatus in the alimentary canal, and it is also easy to see the contractions of the dorsal blood vessel through the more or less transparent body wall. This last fact is of special importance as it makes it practicable to leave the animal undisturbed in its constant temperature bath, thus obviating any disturbance of the vascular contractions through nervous action due to stimulation from without.

\section{Methods.}

As a preliminary to the actual temperature work a number of worms were subjected to immersion, for varying periods, in water to ascertain what harmful effects might result. Without going into detail as to this work it may be stated that the worms are able to withstand immersion in tap water for a sufficient time to allow all the experimentation needed for the temperature studies, without showing any harmful effects. In fact certain worms have been immersed for as long a period as two weeks without showing any injurious effects.

The temperatures of the worms were regulated, then, by placing them in baths of water, the temperature of which was controlled by placing the dishes in thermostats having practically constant temperatures, in refrigerators cooled by ice, or in the running water of the laboratory, which was found to have a very constant temperature.

The temperatures of the worms were determined by means of

${ }^{1}$ Snyder, C. D., “On an Interpolation Formula Used in Calculating Temperature Coefficients for Velocity of Vital Activities, Together with a Note on the Velocity of Nerve Conduction in Man," Science, N.S., Vol. XXXIV., No. 874, p. 4I5. 
delicate clinical thermometers, in the form of thermo-couples, which could be inserted into the mouths of the worms and pushed on down into the stomach intestine. These thermo-couples were made of No. 32 copper and No. 32 constantan wires. Any difference in the temperature of the two junctions of the couple sets up an electromotive-force proportional in its strength to the amount of the temperature difference, and which can be accurately measured by means of a delicate galvanometer. In this particular work it was found that $\mathrm{I}^{\circ} \mathrm{C}$. was represented by a shift in the reading of the galvanometer scale of about $\mathrm{I} 6 \mathrm{~mm}$. As it was practicable to read to half millimeters it will be seen that a temperature difference of $0.03^{\circ}$ could be determined. For a somewhat more detailed account of the method of temperature measurements the reader is referred to another paper. ${ }^{1}$

The worm having been subjected to a given temperature for a sufficient length of time to have become completely adjusted to the new condition, the temperature of the worm was noted, and the length of time required for a definite number of beats of the dorsal blood-vessel, usually 25, was taken by means of a stopwatch reading to fifths of a second. The worm was then changed to another bath at a different temperature, allowed to remain long enough to become thoroughly adjusted to the new condition, and another reading of the rate of contraction of the dorsal blood vessel made. From the data thus obtained the temperature coefficient of the rate of contraction was calculated by means of the formula referred to above.

It may be said that all possible precautions were taken to avoid serious errors in the work. Temperatures were determined by making the readings of the galvanometer against a certified thermometer calibrated to tenths of a degree C. The temperatures of the various baths were kept as uniformly constant as possible and the exact temperature taken each time a count was made. Occasionally one is in doubt as to whether a contraction of the dorsal blood vessel has actually taken place. In such a case the reading was thrown out and another made so as to make sure of the fact. The temperature of the room was kept as constant as possible in order to avoid any changes of resistance

${ }^{1}$ Rogers, Charles G., and Lewis, Elsie M., l. c. 
in the copper wires and in the galvanometer which might tend to disturb the results. Manipulation of the worms was reduced to a minimum in order that nervous effects might not be introduced to invalidate the temperature effects. Reading of the rates of contraction of the dorsal blood vessel before and after the insertion of the glass covered junction indicated that the mere insertion of the instrument in the alimentary canal made no difference with the rate.

TABLE I.

\begin{tabular}{|c|c|c|c|c|c|}
\hline $\begin{array}{l}\text { No. of } \\
\text { Worm. }\end{array}$ & $K_{1}$ & $K_{0}$ & $T_{1}$ & $T_{0}$ & $Q_{10}$ \\
\hline 3 & I9.35 & I3.74 & $2 \mathrm{I} .43^{\circ}$ & I $1.60^{\circ}$ & I. 406 \\
\hline 5 & I 5.00 & 9.80 & I $8.00^{\circ}$ & I I. $50^{\circ}$ & I.925 \\
\hline 6 & 20.35 & I0.90 & I $8.00^{\circ}$ & I I. $50^{\circ}$ & 2.593 \\
\hline 7 & 2I.IO & I3.80 & I6.04 & II. $50^{\circ}$ & 2.548 \\
\hline 8 & I 5.72 & 8.92 & I6.04 & II. $50^{\circ}$ & 2.096 \\
\hline 9 & 22.00 & 9.93 & I $6.04^{\circ}$ & II. $50^{\circ}$ & 5.766 \\
\hline IO & I6.93 & I 0.60 & I6.0 $4^{\circ}$ & II. $50^{\circ}$ & 2.805 \\
\hline I I & I 7.75 & I I. 29 & I6.04 & I I. $50^{\circ}$ & 2.642 \\
\hline I 2 & I 4.79 & I I. 76 & I6.0 $4^{\circ}$ & I I. $50^{\circ}$ & I. 656 \\
\hline I 4 & 27.00 & I9.40 & $26.40^{\circ}$ & II. $70^{\circ}$ & I. 272 \\
\hline I6 & 26.90 & I 4.92 & $26.40^{\circ}$ & I $1.60^{\circ}$ & I. 485 \\
\hline I 7 & I 5.27 & I I.I3 & $26.50^{\circ}$ & I I. $60^{\circ}$ & I. 236 \\
\hline I 8 & I9.70 & I 5.33 & $26.50^{\circ}$ & I I. $60^{\circ}$ & I. I 76 \\
\hline I9 & 29.30 & I 2.50 & $27.13^{\circ}$ & I $2.55^{\circ}$ & I. 793 \\
\hline $2 I$ & 24. I 5 & $\mathrm{I} 3.50$ & $27.12^{\circ}$ & I $2.55^{\circ}$ & I. 280 \\
\hline 24 & 33.60 & 24.00 & $27.00^{\circ}$ & $16.36^{\circ}$ & I. 372 \\
\hline 26 & 37.80 & 26.70 & $26.60^{\circ}$ & $24.60^{\circ}$ & 5.754 \\
\hline 27 & 32.56 & I9.35 & $20.00^{\circ}$ & $9.50^{\circ}$ & 2.044 \\
\hline 28 & 35.27 & 24.55 & $20.00^{\circ}$ & $9.50^{\circ}$ & I. $4 \mathrm{I} 3$ \\
\hline 29 & 21.39 & 8.85 & $27.50^{\circ}$ & $14.00^{\circ}$ & I. $62 \mathrm{I}$ \\
\hline 30 & 28.20 & I 2.13 & $27.10^{\circ}$ & I $4.00^{\circ}$ & I.899 \\
\hline $3 I$ & 20.40 & I3.I 8 & $27.70^{\circ}$ & $\mathrm{I} 4.00^{\circ}$ & I. 365 \\
\hline 32 & 27.48 & I I. 75 & $27.30^{\circ}$ & $\mathrm{I} 4.04^{\circ}$ & I. 898 \\
\hline 33 & $2 \mathrm{I} .50$ & I 2.66 & $26.50^{\circ}$ & $\mathrm{I} 4.02^{\circ}$ & I. 525 \\
\hline 34 & 26.55 & 14.05 & $25.60^{\circ}$ & $14.03^{\circ}$ & I. 733 \\
\hline 35 & 22.00 & I 2.95 & $25.08^{\circ}$ & I $3.88^{\circ}$ & I. 605 \\
\hline 36 & 24.86 & I 2.63 & $25.08^{\circ}$ & I $3.92^{\circ}$ & I. 838 \\
\hline 37 & I6.97 & 8.95 & $22.54^{\circ}$ & I3.95 & 2.109 \\
\hline 38 & 20.40 & I I. 58 & $22.46^{\circ}$ & $13.96^{\circ}$ & I. 947 \\
\hline 39 & 22.43 & I I. 86 & $21.86^{\circ}$ & I3.94 $4^{\circ}$ & 2.236 \\
\hline 40 & 21.59 & $9.8 \mathrm{I}$ & $2 \mathrm{I} .43^{\circ}$ & I $3.95^{\circ}$ & $2.87 \mathrm{I}$ \\
\hline $4 \mathrm{I}$ & 26.80 & II.I6 & $22.90^{\circ}$ & I $3.72^{\circ}$ & 2.603 \\
\hline 42 & 21.97 & II.IO & $22.95^{\circ}$ & $13.74^{\circ}$ & 2.099 \\
\hline 43 & 23.33 & I I.94 & $22.7 \mathrm{I}^{\circ}$ & I $3.80^{\circ}$ & 2. I $2 \mathrm{I}$ \\
\hline 44 & 25.00 & I I. 23 & $23.18^{\circ}$ & $13.73^{\circ}$ & 2.388 \\
\hline \multicolumn{5}{|c|}{ Average value of temperature coefficient for all specimens....... } & 2.173 \\
\hline
\end{tabular}

The preceding table, Table I., gives the data derived from the actual experiments and also the values of the temperature coefficient calculated from the data. In the tables the letters 
$K_{1}$ and $K_{0}$ indicate the rates in contractions per minute at the temperatures $T_{1}$ and $T_{0}$ respectively, in degrees Centigrade.

If we arrange the data of Table $I$. so as to show the relation existing between the higher and lower temperature ranges and the value of $Q_{10}$ we have evidence that for the lower temperatures there is a higher coefficient than for the higher ranges. This fact is not so clearly shown in the case of the earthworm as in some of the forms already studied, probably for the reason that it is very difficult to count the beats of the dorsal blood vessel of the earthworm at temperatures below $8^{\circ} \mathrm{C}$. The movements of the walls are so feeble and so slow that one is not sure when a contraction has taken place.

TABle II.

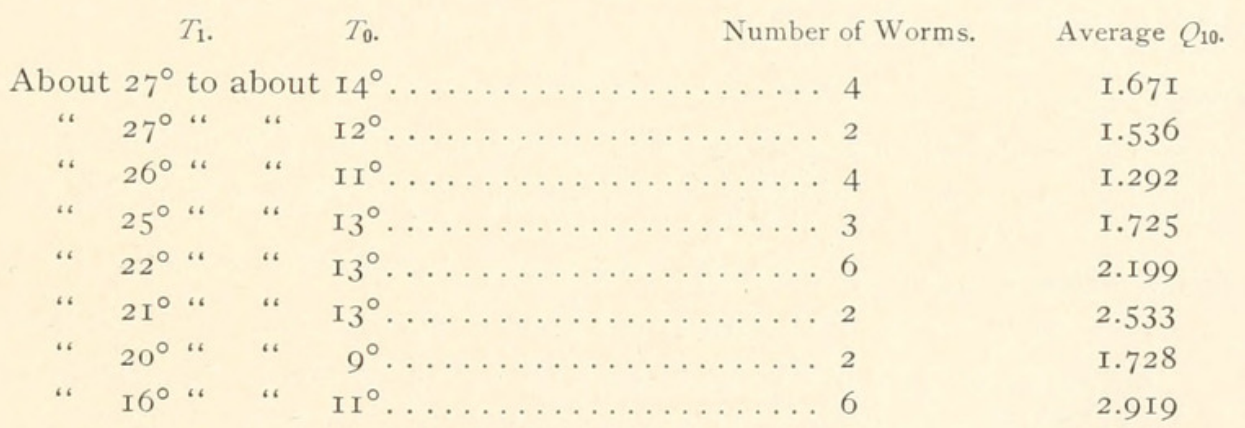

In Table II. we have such an arrangement of the data as suggested in the preceding paragraph. It will be noted that while in general the coefficients for the lower ranges are higher than those for the higher ranges of temperature, there are very marked exceptions to the rule. The only explanation we have to offer at this time for the rather marked variation from what we should expect, if the beat of the dorsal blood vessel of the earthworm is subject to the same laws as the beats of various hearts already studied, is that we have here to deal with a series of nervous effects which must be in some way eliminated in order to avoid complications. Up to the present time we have not found any means of avoiding these nervous effects in the worm, though in fish embryos where the rate of heart beat was studied before the nervous connections were established it was found that one could predict with some degree of certainty what the rate of heart contraction should be at any stated temperature. 
That the rate of beat of the dorsal blood vessel of the earthworm is to some extent under the control of the nervous system will be shown in another publication from this laboratory.

It is to be noted also that the temperature coefficient of the rate of contraction of the dorsal blood vessel of the earthworm is, for the temperatures at which the worm would naturally live, of the same general magnitude as those of chemical reactions, and the average for the whole series, 2.I73, also falls within the limits usually set for the temperature coefficients of such reactions. We have no reason, as yet, to assign for the much reduced coefficients for the higher temperature ranges.

\section{BIBLIOGRAPHY.}

Loeb, Jacques and Ewald, W. F.

'I3 Die Frequenz der Herztätigkeit als eindeutige Funktion der Temperatur. Biochemisches Zeitschrift, Bd. 58, pp. I77-185.

Rogers, Charles G.

'I I Studies upon the Temperature Coefficient of the Rate of Heart Beat of Certain Living Animals. American Journal of Physiology, Vol. 28, pp. 8I-93.

Snyder, Charles D.

On the Influence of Tempe:ature upon Cardiac Contraction and its Relation to Influence of Temperature upon Chemical Reaction Velocity. University of California Publications, Physiology, Vol. 2, pp. I25-I46.

\section{Snyder, Charles D.}

On an Interpolation Formula used in Calculating Temperature Coefficients for the Velocity of Vital Activities, together with a note on Nerve Conduction. Science, N.S., Vol. 34, No. 874, p. 4I5.

\section{Snyder, Charles D.}

The Influence of Temperature upon the Rate of Heart Beat in the Light of the Law for Chemical Reaction Velocity. American Journal of Physiology, I906, Vol. I 7, No. 4.

\section{Snyder, Charles D.}

The Temperature Coefficient of the Velocity of Nerve Conduction. American Journal of Physiology, I908, Vol. 22, No. I.

\section{Snyder, Charles D.}

A Comparative study of the Temperature Coefficients of the Velocities of Various Physiological Actions. American Journal of Physiology, I908, Vol. 22, No. 3 .

Woodruff, L. L. and Baitsell, G. A.

The Temperature Coefficient of the Rate of Reproduction of Paramoecium aurelia. American Journal of Physiology, I9I I, Vol. 29, No. 2. 


\section{AUDITORY POWERS OF THE CATOCALA MOTHS; AN EXPERIMENTAL FIELD STUDY. ${ }^{1}$}

\section{H. TURNER AND E. SCHWARZ.}

\section{Historical Resumé.}

Near the close of the nineteenth century, Romanes ('9I) wrote: "Among insects organs of hearing certainly occur, at least in some, although the experiments of Sir John Lubbock appear to show that ants are deaf. The evidence that some insects are able to hear is not only morphological, but also physiological, because it is only on the supposition that they do that the fact of stridulation and other sexual sounds being made by certain insects can be explained, and Brunelli found that when he separated a female grasshopper from the male by a distance of several meters, the male began to stridulate in order to inform her of his position, upon which the female approached him. I have myself published observations proving the occurrence of a sense of hearing among the Lepidoptera."

The tone of three fourths of the above paragraph is characteristic of practically all of the early works upon the auditory powers of insects. Those men were convinced that insects hear; not because they had experimentally demonstrated it, but for morphological reasons, and because many kinds of insects can produce sounds. They believed that an insect would not be endowed with the power of producing sounds unless the other members of the species could hear. At first in the Orthoptera and later in other groups of insects, peculiar organs were found; consisting essentially of vibratory hairs attached to certain cells that seem to be sensory in nature. In some cases these hairs are in cavities and in others they are not. Such was the nature of the work of Siebold ('44), Leydig ('55), Henson ('66), Lee ('83, '85), Graber ('75, '82), Weinland ('9r), Adelung ('92) and others. As late as 1905 Radl expressed the following thought. No matter

${ }^{1}$ For the identification of the species and for the experimental work on C. unijuga, E. Schwarz alone is responsible; the field work was performed jointly; for the planning of the work, for the historical resume and for the method of treatment, C. H. Turner is solely responsible. 
how often in recent years doubt has arisen as to the ability of insects to hear, it has been largely maintained that they possess an auditory sense, and for the following two reasons: (I) the ability of many insects to produce sounds as a part of their normal behavior; (2) the possession by insects of organs which structurally seem fitted to act as receptors of sound waves.

Students interested in the morphological method of investigating this question will find the paper by Radl ('05) intensely interesting. After epitomizing the work by Lee ('83, '85), by Graber ('82), and by Weinland ('9I), he states that, on a priori grounds, he doubted the assumptions of Graber; but that certain experiments had convinced him that insects have a crude auditory sense. In support of his contention, he offers the following reasons.

I. Graber is inaccurate when he claims that the chordotonal organs are located rigidly between two immovable parts of the body; for the proximal end is attached to an indifferent part of the body, while the distal end is in close proximity to one or more muscles.

2. The chordotonal organ cannot function like a string attuned to a certain pitch; because it expands and contracts.

3. All of the chordotonal organs examined are attached at each end to a chitinous framework and the nerve penetrates from the side.

4. The chordotonal organs resemble somewhat those muscles which occur especially in the limbs of the Arthropoda-muscles which terminate in long tendons.

5. No chordotonal organ is found in either the Myriapoda or the Arachnida.

6. Chordotonal organs are found in some insects for which a sense of hearing could have no significance. They are well developed in caterpillars; even in those of the Tortricidæ, which spend the entire larvel period inside of some fruit. They are also well developed in the internal parasites of certain insects.

7. All attempts to determine experimentally that insects react to pure and simple tones have yielded negative results: however, it is comparatively easy to evoke responses of insects to shrill noises, such as the voice of a cricket or the screech produced by 
drawing a file across the edge of an iron or a glass plate. This is not a tactile reaction.

8. There is no evidence that noise, as such, causes the orientation of insects. The sounds produced by insects are more an outburst of inner feeling than an attempt to entice the female by the male.

9. The outcome of the whole matter is that there is an auditory sense in insects; but, it is on a much lower plane of development than that of the vertebrates. Its anatomical and physiological antecedents are to be found, not in the tactile organs and contact activities; but, anatomically in sense organs which register muscle activities and physiologically in general sensation (Gemeingefuhlen). The auditory sense of insects is a highly refined muscular sense.

Although the work of the early investigators was largely, often entirely, morphological, it must not be concluded that no experimental work has been done on the auditory powers of insects and their near kin. Such experiments have been performed in several groups of insects; but the results are inharmonious. Buttel-Reepen ('oo) and De Fraviere believe that bees can hear. Buttel-Reepen's statement is based upon his observation that bees respond in a definite manner to the sounds of their own kind.

Huber ('IO) and Forel ('o3) interpret their experiments to mean that ants cannot hear. Lubbock's experiments likewise yielded negative results; yet, in spite of this, he was unwilling to admit that ants, wasps and bees cannot hear. Weld ('99) thinks he has experimentally demonstrated that ants can hear. Fielde and Parker ('o4) interpret their experiments to mean that ants do not respond to sound vibrations as such. C. H. Turner ('o7) is equally positive that his experiments demonstrate that ants can hear. At one time Wheeler believed, not only that ants can hear; but that they communicate by means of sounds; but, after the appearance of the paper by Fielde and Parker, he ('Io) asserts that there is not sufficient evidence to warrant the assumption that ants can hear.

E. A. Andrews ('II) is convinced that termites hear. He writes: "In a community suspended from the ceiling by a copper 
wire and represented by many thousands on a moist block of artificial stone which they got to from the nest by means of a long stick as bridge, it was first observed by Mr. Middleton that the noise of thunder and of blasting rocks was followed by a quick and very remarkable departure of almost all of the termites towards the nest. The blocks of stone weighed some sixteen pounds each and rested in a large pan of water on a firm wall of stone, so that it seemed likely that the concussion of the air came to the termites directly and not as a tremor of the stones they were clustered on. The same precipitous flight of the multitude of termites from these stones to the nest along the bridge was brought about by dropping a board upon the concrete floor with a loud crash. Even the clapping of hands, which probably shook the stone foundation but imperceptibly, served to drive the termites back to the nest. . . . Attempts to influence the termites by blowing horns of various pitches near them failed though considerable disturbance of the air was produced."

Montgomery ('IO), after reviewing all that had been written on the auditory powers of spiders, concludes that spiders are deaf.

The above is not an exhaustive discussion of the published research work on the auditory powers of insects other than the Lepidoptera; yet, we trust it is sufficient to show the inharmoniousness of the results of different investigators.

To the best of our knowledge, the first published results of experiments upon the auditory powers of butterflies and moths is an article by Romanes ('76) which appeared about thirty-six years ago. The portion referring to the Lepidoptera is so short that we quote it in full. "It seems worth while to add a few words with respect to the sense of hearing in insects. So far as I am aware, the occurrence of such a sense in this class has never been actually proved. Although on a priori grounds there can scarcely be any doubt concerning the fact of some insects being able to hear; seeing that in so many species stridulation and other sounds are made during the season of courtship. In the case of moths, however, I believe that sounds are never emitted-except, of course, the death's head moth. ${ }^{1}$ It therefore becomes inter-

${ }^{1}$ Romanes was mistaken when he asserted that the death's head moth is the only Lepidopteran than produces sounds; for the literature contains records of 
esting to observe that an auditory sense is certainly present in these insects. Several kinds of moths have the habit of gently, though very rapidly, vibrating their wings, while they themselves are at rest on a flower or other surface. If, while this vibrating movement of the wings is going on, the observer makes a sudden shrill note with a violin, or fife, etc., the vibrating movement immediately ceases, and sometimes the whole body of the insect gives a sudden start. These marked indications of hearing I found invariably to follow a note with a high pitch, but not a note with a low one."

Heinrich ('o9) remarks that collectors using a net to capture Limenitis populi and Catocala fraxini have observed that the insects often take flight before a collector is near enough to capture them. Accordingly to him no conclusive evidence has been published on the sense of hearing of insects, especially of the Lepidoptera. He noticed a Laurentia suffumata alight in a concert pavilion and remain quietly while the brass band played three selections, one of which was Wagner's Götterdammerung. He also noticed that certain Lepidoptera were more easily approached at twilight than when the sun was shining brightly, and he could not understand why this should be true if they were warned by a sense of hearing. He is convinced that, in all of these cases, it is vision, not audition, that warns butterflies and moths of the approach of man.

Hamann ('o9) was led to investigate this subject by the remarks of collectors that butterflies and moths undoubtedly hear. One collector remarked that the noise caused by removing the cork from the cyanide bottle often caused these insects to fly. To this Haman replies that since the net is usually placed beneath the insect before the cork is removed it is probable that the sight of the net caused the flight. To test the matter, the following experiments were performed by him. (I) He approached a tree in such a manner as to be invisible to an Apatura iris L. resting thereon, and struck the tree with the bamboo handle of his several species of Lepidoptera that emit sounds. Indeed, scarcely had his article appeared before several of his contemporaries published, in Nature, protests in which were cited several examples of sound-producing Lepidoptera. Recently Omensetter ('I2) and Stephan ('I2) have described several sound-producing forms of butterflies and moths. 
collecting net. To this the insect made no response; but, as soon as the net approached it took flight. (2) a repetition of the experiment with Vanessa yielded similar results. (3) He noticed that certain Catocalas, which were not disturbed by the noise of a passing automobile, flew upon the approach of man. These experiments convinced him that butterflies and moths cannot hear.

Deegener's work ('o9) is morphological. Between the thorax and the abdomen, on the ventral side of the body of all species of Nocturidæ, there is a depression containing chitinous structures and hairs which are connected with what seem to be sensory cells. A careful examination of this organ in Pseudophia lunaris convinced Deegan that it is probably an auditory organ.

Rothke ('o9) confined a Limenitis artemis in a cage which he placed on the top of a pedestal two feet high. The sides and back of this cage were constructed of wood; but the front was covered with wire fly netting. At nine P.M., while the front of the cage was illuminated by means of a kerosene lamp, Rcthke stepped to one side and made a slight noise. To this the insect made no response. The investigator then tapped rapidly and sharply upon the floor with a leather slipper. Although the jar was not sufficient to shake the stand upon which the cage rested, and although the investigator could not be seen by the insect, yet it slowly raised its wings until they met above its back and then lowered them again. Several repetitions of this experiment yielded identical results. During the intervals between the experiments the creature remained immobile. After the moth had been quiet for one quarter of an hour, Rothke rapped upon the table with a tumbler. Immediately the insect flapped its wings. About midday he discovered a specimen of Catocala unijuga resting quietly, about six feet from the ground, upon a pine tree one and a half feet in diameter. He picked up a stone about fifteen centimeters in diameter and threw it against the tree-trunk. Although the moth could not see the stone and although the blow was too slight to jar such a large tree, yet the moth flew away. Rothke is convinced that butterflies and moths can hear.

Observations made upon Catocala pacta L. convinced Richter 
('og) that the crackling of twigs under his feet and even the slight noise made by removing the cork from his collecting bottle disturbed this moth. In another article, the same investigator ('Io) has made a comparative study of the auditory powers of day-flying and night-flying Lepidoptera. He investigated the day-flyers; A patura sp., Vanessa sp., Limenitis populi L., and Sat. alcyone Schiff. He found that species of Apatura and of Vanessa made no responses to sound so long as no visible object disturbed them. During a severe storm, he noticed a number of Sat. alcyone perching on a limb. Neither whistling, nor the clapping of hands, nor shaking of the limb had any effect on them: but, as soon as the hand of the collector approached them, they flew. A Vanessa antiopa, resting on a telegraph pole, was not disturbed by the shrill whistle and the rumbling noise of a passing train. In studying Catocala fraxini L., a night-flying moth, he noticed that it made no responses to the noises made by wagons, automobiles and the bells of a ferry; but that it responded readily to slight, high-pitched, sounds. He argues that the failure of this moth to respond to the sounds made by wagons and such things is because such sounds have no life significance for the moth. On the other hand, the ready response to the other sounds mentioned is due to their similarity to sounds made by field-mice, bats and owls - sounds which for the moth have a pronounced life significance. Partly influenced by the knowledge that Geegener had discovered chordotonal organs in the Noctuidæ and more so by the observations just described, Richter is convinced that day-flying Lepidoptera are warned by visual and night-flying forms by auditory stimuli.

For years Rober ('Io) has raised Acerontia atropos L. from pupae. Late one evening a female emerged and, before her wings were fully dried, a male emerged in the cage. In order to separate the two, the female was removed to a cage in the bottom of which there was a crack as wide as one's finger. These cages were three meters apart. In the morning the female, which had escaped from confinement, was found perched on the cage containing the male. A person who slept in the room with these two moths asserts that, for a long time that evening, those moths emitted sounds. Rober concludes that these were love calls and that the 
moths mutually heard. In face of the well known fact that the sense of smell is well developed in butterflies and moths, the evidence just cited does not appear to be conclusive.

Is it possible for anyone to read the above historical resume and not be convinced that there is need for much exact experimentation upon the auditory powers of insects? Evidently the last word has not been spoken.

\section{Description and Discussion of Experiments.}

Reading Stephan's ('I2) recent articles on sound producing butterflies and moths induced in us the same thought that influenced the opinions of many of the early investigators; namely, animals that produce sounds as a part of their normal behavior can probably hear. We decided to make some crucial experiments. The Catocala moths were selected for the following reasons: (I) one of us is so well acquainted with the taxonomy of the group that it is easy to identify species afield; (2) the habit these moths have of resting during the day on some tree trunk and, when disturbed, flying to a nearby tree trunk renders them ideal material for field experiments.

\section{Preliminary Observations.}

Observations afield taught us that there are certain sounds to which these moths do not respond. A favorite haunt of the Catocala moths of this vicinity is a small stretch of wood through which a railroad passes. Moths resting on trees near the tract are not disturbed by the whistle, rumble and roar of passing trains. Near that same place there is a pleasure garden in which the sounds of a noisy piano are often heard. No responses to the strains of the piano were noticed.

These observations are in harmony 'with those of Heinrich ('o9), Hamann ('o9) and Richter ('o9, 'io).

\section{IndOOR EXPERIMENTS ON CATOCALA UNIJUGA.}

Three specimens freshly hatched from pupae were the subjects of these experiments. Each was kept in a separate room. Three times a day, for four days, the auditory powers of these moths was tested by whistling in a high key. Occasionally the moth was shielded from the draft of air caused by whistling; 


\section{TABLE I.}

Catocala unijuga. Specimen Number i.

\begin{tabular}{|c|c|c|c|c|}
\hline $\begin{array}{c}\text { Number } \\
\text { of the } \\
\text { Experiment. }\end{array}$ & Date. & $\begin{array}{l}\text { Whistled, the } \\
\text { Insect Shielded } \\
\text { from the Air } \\
\text { Currents. }\end{array}$ & $\begin{array}{l}\text { Whistled, the } \\
\text { Insect Not } \\
\text { Shielded from } \\
\text { the Air Currents. }\end{array}$ & $\begin{array}{l}\text { Number of } \\
\text { Times it Was } \\
\text { Necessary to } \\
\text { Whistle Before } \\
\text { Response Was } \\
\text { Received. }\end{array}$ \\
\hline I & June 5, I9I3, Io:00 A.M... & $N$ & & \\
\hline 2 & , & & $F$ & I \\
\hline 3 & " $\quad \ldots$ & & $F$ & I \\
\hline 4 & $\cdots$ & $F$ & & 4 \\
\hline 5 & $\ldots$ & $Q$ & & 5 \\
\hline 6 & June 5 , I9I3, I0:30 A.M... & & $F$ & 2 \\
\hline 7 & $\left.\begin{array}{llll}\prime \prime & & \end{array}\right]$ & $Q$ & & 6 \\
\hline 8 & $\cdots$ & $F$ & & 3 \\
\hline 9 & " & $Q$ & & 8 \\
\hline IO & June 5 , I9I3, 6 P.M....... & $F$ & & 4 \\
\hline I I & 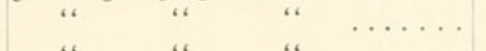 & $Q$ & & 3 \\
\hline $\mathrm{I} 2$ & $" \quad \ldots \ldots \ldots$ & $F$ & & 6 \\
\hline I3 & " $\quad$ " $\quad$ " $\quad \ldots \ldots$ & $Q$ & & IO \\
\hline I 4 & June 6, I9I3, 9:00 A.M.... & $N$ & & \\
\hline I5 & $\begin{array}{llll}\prime \prime & \prime & \ldots & \ldots\end{array}$ & $Q$ & & 4 \\
\hline I6 & $\ldots$ & $F$ & & 2 \\
\hline I 7 & 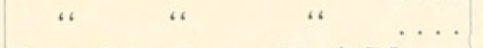 & $Q$ & & 5 \\
\hline I 8 & June 6, I9I3, I I.00 A.M... & $F$ & & 4 \\
\hline I9 & $\begin{array}{llll}\prime \prime & \text { " } & \text { " } & \ldots\end{array}$ & $Q$ & & Io \\
\hline 20 & $\ldots$ & $F$ & & 4 \\
\hline $2 \mathrm{I}$ & " & $Q$ & & I5 \\
\hline 22 & June 6, I9I3, 6:00 P.M.... & $F$ & & 8 \\
\hline 23 & 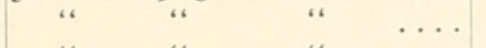 & $Q$ & & I5 \\
\hline 24 & " $\quad \ldots$ & $F$ & & 6 \\
\hline 25 & " $\quad$ " 1406 & $Q$ & & I9 \\
\hline 26 & June 7 , I9I3, 9:00 A.M.... & $F$ & & 4 \\
\hline 27 & " & $Q$ & & IO \\
\hline 28 & “ & $F$ & & 4 \\
\hline 29 & 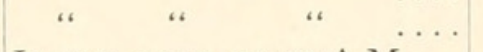 & $Q$ & & 6 \\
\hline 30 & June 7 , I9I3, I0:00 A.M... & $F$ & & 3 \\
\hline $3 \mathrm{I}$ & “ & $Q$ & & 8 \\
\hline 32 & $\cdots$ & $F$ & & 3 \\
\hline 33 & " & $Q$ & & I5 \\
\hline 34 & June 7 , I9I3, 7:00 P.M.... & $F$ & & 6 \\
\hline 35 & “ & $Q$ & & 5 \\
\hline 36 & $\ldots$ & $F$ & & 4 \\
\hline 37 & " & $Q$ & & 6 \\
\hline 38 & June 8, I9I3, I0:00 A.M... & $F$ & & 2 \\
\hline 39 & $\begin{array}{llll}\prime & \| & 4 & \ldots\end{array}$ & $Q$ & & IO \\
\hline 40 & $\ldots$ & $\mathrm{N}_{4}$ & & \\
\hline $4 \mathrm{I}$ & " & $Q$ & & 6 \\
\hline 42 & June 8, I9I3, I0:30 A.M... & $N$ & & \\
\hline 43 & $\cdots$ & $Q$ & & 6 \\
\hline 44 & $\cdots$ & $\mathrm{N}_{2}$ & & \\
\hline 45 & $\cdots$ & $Q$ & & Io \\
\hline 46 & " & $F$ & & 2 \\
\hline 47 & June 8 , I9I3, 6:00 P.M.... & $F$ & & 4 \\
\hline 48 & “ $\quad \ldots$ & $Q$ & & 3 \\
\hline 49 & $\ldots$ & $F$ & & 6 \\
\hline 50 & $\ldots$ & $Q$ & & Io \\
\hline $5 \mathrm{I}$ & $\ldots \ldots$ & $F$ & & I3 \\
\hline
\end{tabular}


Explanation of TABles I-III.

$N$ indicates no response; $F$ means that the moth flew; $Q$ indicates that the insect waved its wings up and down or made some quivering movement.

TABLE II.

Catocala unijuga. SPECIMEN 2.

\begin{tabular}{|c|c|c|c|c|}
\hline $\begin{array}{c}\text { Number } \\
\text { of the } \\
\text { Experiment. }\end{array}$ & Date. & $\begin{array}{l}\text { Whistled, the } \\
\text { Insect Shielded } \\
\text { from the Air } \\
\text { Currents. }\end{array}$ & $\begin{array}{l}\text { Whistled, the } \\
\text { Insect Not } \\
\text { Shielded from } \\
\text { the Air } \\
\text { Currents. }\end{array}$ & $\begin{array}{l}\text { Number of } \\
\text { Times it Was } \\
\text { Necessary to } \\
\text { Whistle Before } \\
\text { the Moth } \\
\text { Responded. }\end{array}$ \\
\hline I & June 6, I9I3, 9:00 A.M.... & $Q$ & & 6 \\
\hline 2 & 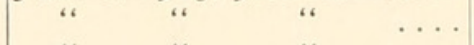 & & $F$ & 2 \\
\hline 3 & $\ldots$ & $F$ & & 5 \\
\hline 4 & " $\quad \ldots$. & $Q$ & & 4 \\
\hline 5 & June 6 , I9I3, I0:00 A.M... & & $F$ & I \\
\hline 6 & {$\left[\begin{array}{llll}\prime & \prime & & \end{array}\right]$} & $F$ & & 4 \\
\hline 7 & $\ldots$ & $Q$ & & 3 \\
\hline 8 & “ & $F$ & & 2 \\
\hline 9 & June 6, I9I3, 6:00 P.M.... & $F$ & & I \\
\hline Io & “ “ “ & $Q$ & & 3 \\
\hline I I & $\ldots$ & $F$ & & 2 \\
\hline 12 & “ & $Q$ & & 6 \\
\hline I3 & June 7 , I9I3, I0:00 A.M... & $F$ & & 2 \\
\hline I 4 & " $\left.\begin{array}{llll} & \end{array}\right]$ & & $F$ & \\
\hline I 5 & “ & $F$ & & 4 \\
\hline I6 & 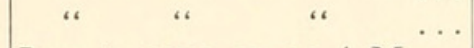 & $Q$ & & 5 \\
\hline I 7 & June 7 , I9I3, I I :00 A.M... & $F$ & & 2 \\
\hline I 8 & 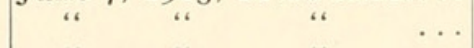 & $Q F$ & & 4 \\
\hline 19 & “ & $F$ & & 4 \\
\hline 20 & $\begin{array}{llll}\text { " } & \text { " } & & \end{array}$ & $Q$ & & 4 \\
\hline $2 I$ & June 7 , I913, 6:00 P.M.... & $F$ & & 3 \\
\hline 22 & " & $Q$ & & 3 \\
\hline 23 & $\cdots$ & $F$ & & 2 \\
\hline 24 & " & $Q$ & & 8 \\
\hline 25 & June 8, I9I3, 9:00 A.M.... & $N$ & & \\
\hline 26 & " & & $F$ & I \\
\hline 27 & $\ldots$ & $Q$ & & 3 \\
\hline 28 & " $\quad$ " $\quad$ " $\quad \ldots$ & $F$ & & 8 \\
\hline 29 & June 8 , I9I3, II:00 A.M... & $F$ & & 4 \\
\hline 30 & $\ldots$ & $Q$ & & 6 \\
\hline $3 I$ & “ “ & $F$ & & 4 \\
\hline 32 & June 8 , I913, $7: 00$ P.M.... & $F$ & & Io \\
\hline 33 & " $\quad$ " $\quad$ " $\quad \ldots \quad \ldots$ & $Q$ & & 6 \\
\hline 34 & $\ldots$ & $F$ & & 2 \\
\hline 35 & 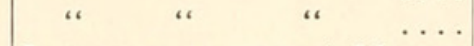 & $Q$ & & 6 \\
\hline 36 & June 9, I9I3, 9:00 A.M.... & & $F$ & 2 \\
\hline 37 & " $\quad$ " $\quad$ " $\quad \ldots$ & $Q$ & & Io \\
\hline 38 & $\ldots$ & $F$ & & 2 \\
\hline 39 & " & $Q$ & & Io \\
\hline 40 & June 9, I9I3, II :00 A.M... & & $F$ & 2 \\
\hline $4 \mathrm{I}$ & 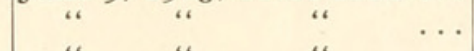 & $Q$ & & 9 \\
\hline 42 & .. & $F$ & & I \\
\hline 43 & $\ldots$ & $Q$ & & II \\
\hline 44 & June 9, I9I3, 7:00 P.M.... & $Q$ & & 6 \\
\hline 45 & “ $\quad \ldots$. & $F$ & & I \\
\hline 46 & $\ldots$ & $Q$ & & 6 \\
\hline 47 & $\ldots$ & $F$ & & Io \\
\hline
\end{tabular}


TABle III.

Catocala unijuga. Specimen Number 3.

\begin{tabular}{|c|c|c|c|c|}
\hline $\begin{array}{c}\text { Number } \\
\text { of the } \\
\text { Experiment. }\end{array}$ & Date. & $\begin{array}{l}\text { Whistled, the } \\
\text { Insect Shielded } \\
\text { from the Air } \\
\text { Currents. }\end{array}$ & $\begin{array}{l}\text { Whistled, the } \\
\text { Insects Not } \\
\text { Shielded } \\
\text { from the Air } \\
\text { Currents. }\end{array}$ & $\begin{array}{l}\text { Number of } \\
\text { Times it Was } \\
\text { Necessary to } \\
\text { Whistle Before } \\
\text { the Response. }\end{array}$ \\
\hline I & June 7 , I9I3, 9:00 A.M.... & $N$ & & \\
\hline 2 & " & & $F$ & I \\
\hline 3 & $\ldots$ & $Q$ & & 3 \\
\hline 4 & $\ldots$ & $F$ & & 2 \\
\hline 5 & " & $Q$ & & Io \\
\hline 6 & June 7 , I9I3, I0:00 A.M... & $F$ & & 2 \\
\hline 7 & " $"$ " 4 & $Q$ & & 6 \\
\hline 8 & $\ldots$ & $F$ & & 2 \\
\hline 9 & " & $Q$ & & IO \\
\hline IO & June 7 , I9I3, $7: 00$ P.M.... & $F$ & & 2 \\
\hline I I & $\left.\begin{array}{llll}\prime & \| & \end{array}\right]$ & $Q$ & & IO \\
\hline I 2 & “ & $F$ & & 4 \\
\hline I3 & 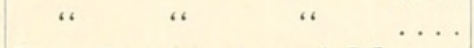 & $Q$ & & I 5 \\
\hline I 4 & June 8, I9I3, 9:00 A.M.... & $F$ & & 3 \\
\hline I 5 & 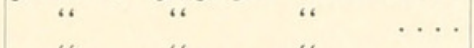 & $Q$ & & 6 \\
\hline I6 & $\cdots$ & $F$ & & 4 \\
\hline I 7 & " & $Q$ & & IO \\
\hline I 8 & June 8, I9I3, Io:00 A.M... & $N$ & & \\
\hline I9 & " $\quad \ldots$ & $Q$ & & Io \\
\hline 20 & $\ldots$ & $F$ & & 6 \\
\hline $2 \mathrm{I}$ & $\begin{array}{llll}\prime & \text { " } & & \end{array}$ & $Q$ & & 5 \\
\hline 22 & June 8, I9I3, Io:00 P.M... & $F$ & & 6 \\
\hline 23 & 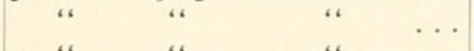 & $Q$ & & 4 \\
\hline 24 & $\begin{array}{llll}\prime & \prime & & \end{array}$ & $F$ & & 4 \\
\hline 25 & $\left.\begin{array}{llll}\prime \prime & 4 & & \end{array}\right]$ & $Q$ & & IO \\
\hline 26 & June 9, I9I3, 9:00 A.M.... & $F$ & & 4 \\
\hline 27 & " & $Q$ & & 3 \\
\hline 28 & $\ldots$ & $F$ & & 6 \\
\hline 29 & 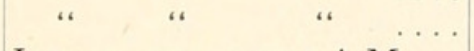 & $Q$ & & Io \\
\hline 30 & June 9, I9I3, II :00 A.M... & $F$ & & 6 \\
\hline $3 I$ & $\begin{array}{llll}\| & \| & \| & \ldots\end{array}$ & $Q$ & & Io \\
\hline 32 & “ & $F$ & & 5 \\
\hline 33 & 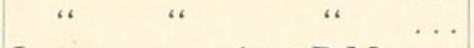 & $Q$ & & 8 \\
\hline 34 & June 9, I9I3, 6:00 P.M.... & $F$ & & Io \\
\hline 35 & " $"$ " $\quad$ " $\quad \ldots$ & $Q$ & & 2 \\
\hline 36 & $\cdots$ & $F$ & & 4 \\
\hline 37 & " & $Q$ & & 6 \\
\hline 38 & June Io, I9I3, 9:00 A.M... & $Q$ & & I \\
\hline 39 & $" \cdots \quad \ldots$ & $N$ & & \\
\hline 40 & $\cdots$ & $Q$ & & 6 \\
\hline $4 \mathrm{I}$ & $\cdots$ & $F$ & & 2 \\
\hline 42 & 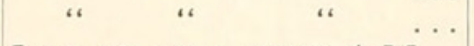 & $Q$ & & 7 \\
\hline 43 & June I0, I9I3, II:00 A.M... & $N$ & & \\
\hline 44 & “ & $Q$ & & 3 \\
\hline 45 & " & $F$ & & I \\
\hline 46 & " & $Q$ & & II \\
\hline 47 & June Io, I9I3, 6:00 P.M... & $N$ & & \\
\hline 48 & $\ldots$ & $F$ & & 2 \\
\hline 49 & $\cdots$ & $Q$ & & 6 \\
\hline 50 & $\cdots$ & $F$ & & I \\
\hline $5 \mathrm{I}$ & $\cdots$ & $Q$ & & Io \\
\hline
\end{tabular}


but, in some cases, the air current was allowed to strike the moth. The results of those experiments are recorded in tables I.-III.

On the twelfth of June the three specimens, which, up to that time, had been confined in separate rooms, were marked and placed in the same room. At nine A.M. that day, on the first sound of the whistle, they all flew, one after another, as though the flight of the first had evoked the flight of the others. At ten o'clock, the whistling caused two to fly and the other to quiver. The one that quivered was about ten feet away. On whistling again all flew. At six P.M. the whistling caused all to fly.

To our way of thinking this series of experiments is very instructive. That each of these three specimens responded to the whistle on the twelfth of June is unequivocal; that they usually responded to the whistle by either flying or by quivering is also evident; but, it is equally certain that two out of the three specimens did not respond to the whistle at all the first time it was sounded and that the third specimen responded in a feeble manner. When the moths did not respond to the blowing of the whistle at the beginning of the experiment, the current of air produced by whistling was allowed to strike the moth; immediately it flew, and thereafter it would usually fly when the whistle was sounded. There were some exceptions to this; but, in the main it was true. This seems a hint that the moth responds to sounds that have a life significance.

\section{Field Experiments.}

These experiments were conducted in a small stretch of woods at Meramec Highlands, near St. Louis, Mo. Previous experience had taught us that these insects would not respond to loud sounds of low pitch. For that reason we used as the sound producing instrument a Galton whistle set to give a high shrill note. One of us would stand where the moth could be observed; but far enough away not to disturb it. Experience had taught us what would be a safe distance. The other, whistle in hand, would approach the tree on the opposite side to that on which the moth was resting. When this experimenter was near to the tree the whistle was held at about the level of the moth and sounded one or more times. In such a position it was absolutely impossible for the moth to see either the whistle or the experimenter. The 
whistle was usually $\mathrm{I} 80^{\circ}$ from the moth; but occasionally it was placed ten to fifteen degrees away, but out of sight of the moth. In a few rare cases, for a special purpose, the whistle was blown in the presence of the moth. Whenever that was done it is indicated in the tables. The results of these experiments are recorded in Tables IV.-XI. The tables are self explanatory.

TABLE IV.

Responses of Catocala flebilis to Sound.

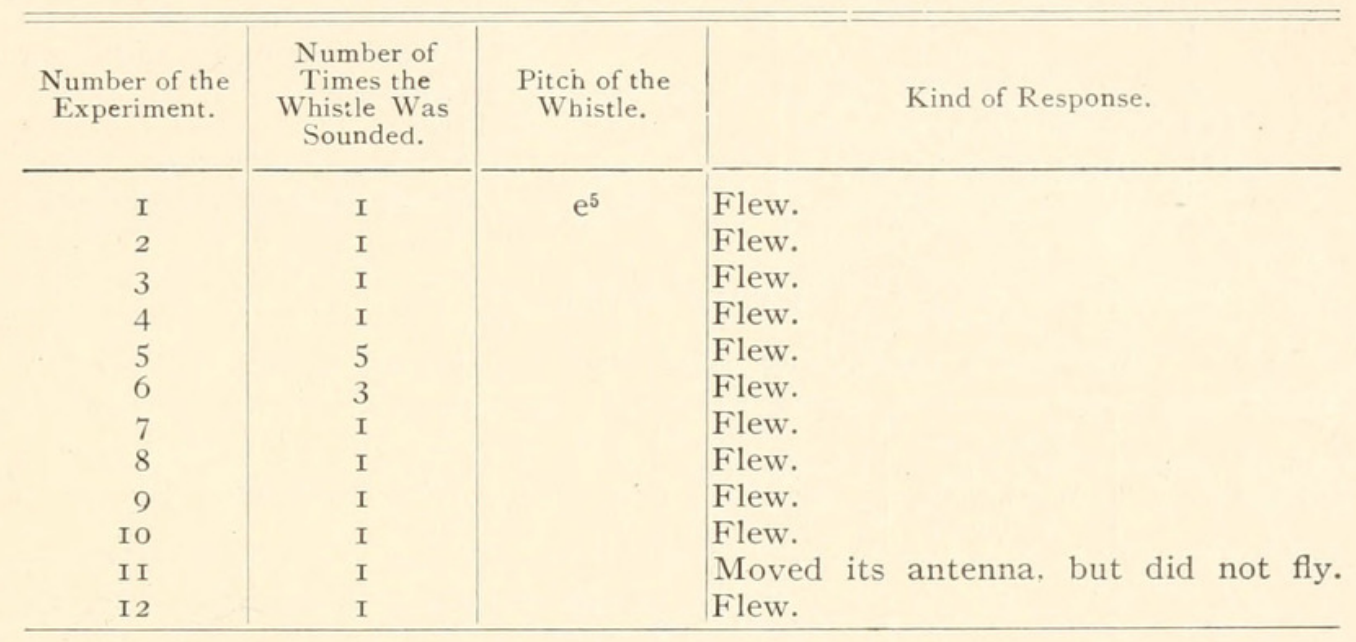

TABLE V.

Responses of Catocala habilis to Sound.

\begin{tabular}{c|c|c|c}
\hline $\begin{array}{c}\text { Number of the } \\
\text { Experiment. }\end{array}$ & $\begin{array}{c}\text { Number of Times } \\
\text { the Whistle Was } \\
\text { Sounded. }\end{array}$ & $\begin{array}{c}\text { Pitch of the } \\
\text { Whistle. }\end{array}$ & Kind of Response. \\
I & I & $\mathrm{a}^{4}$ & Flew. \\
2 & I & & Flew. \\
3 & I & & Flew. \\
4 & I & Flew. \\
5 & I & Flew. \\
6 & I & Flew. \\
\hline
\end{tabular}

In the experiments recorded in this table (Table V.) the Galton whistle was held three feet from the tree on which the moth was resting.

TABLE VI.

Responses of Catocala neogama to Sound.

\begin{tabular}{|c|c|c|c|}
\hline $\begin{array}{l}\text { Number of the } \\
\text { Experiment. }\end{array}$ & $\begin{array}{l}\text { Number of Times } \\
\text { the Whistle Was } \\
\text { Sounded. }\end{array}$ & $\begin{array}{l}\text { Pitch of the } \\
\text { Whistle. }\end{array}$ & Kind of Response. \\
\hline $\begin{array}{l}\text { I } \\
2 \\
3 \\
4 \\
5\end{array}$ & $\begin{array}{l}\text { I } \\
\text { I } \\
\text { I } \\
\text { I } \\
\text { I }\end{array}$ & $\begin{array}{l}\mathrm{e}^{5} \\
\mathrm{a}^{4} \\
\mathrm{a}^{4}\end{array}$ & $\begin{array}{l}\text { No response. } \\
\text { No response. } \\
\text { Flew (saw the whistle). } \\
\text { Flew. } \\
\text { Flew. }\end{array}$ \\
\hline
\end{tabular}


TABLE VII.

RESPONSES of Catocala piatrix to Sound.

\begin{tabular}{|c|c|c|c|}
\hline $\begin{array}{l}\text { Number of the } \\
\text { Experiment. }\end{array}$ & $\begin{array}{l}\text { Number of Times } \\
\text { the Whistle Was } \\
\text { Sounded. }\end{array}$ & $\begin{array}{l}\text { Pitch of the } \\
\text { Whistle. }\end{array}$ & Kind of Response. \\
\hline $\begin{array}{r}\text { I } \\
2 \\
3 \\
4 \\
5 \\
6 \\
7 \\
8 \\
9 \\
\text { IO } \\
\text { I I } \\
\text { I } 2\end{array}$ & $\begin{array}{r}2 \\
I \\
I \\
I \\
I \\
I \\
I \\
I \\
I \\
I \\
I \\
I\end{array}$ & $\mathrm{~b}^{4}$ & $\begin{array}{l}\text { No response observed. } \\
\text { Flew. } \\
\text { Flew. } \\
\text { Moved its wings up and down } \\
\text { Ditto. } \\
\text { Flew. } \\
\text { No response observed. } \\
\text { Moved its wings up and down } \\
\text { Ditto. } \\
\text { Flew. } \\
\text { No response observed. } \\
\text { Moved its wing up and down. }\end{array}$ \\
\hline
\end{tabular}

TABle VIII.

RESPONSES of Catocala relicta var. luctuosa to Sound.

\begin{tabular}{|c|c|c|c|}
\hline $\begin{array}{l}\text { Number of the } \\
\text { Experiment. }\end{array}$ & $\begin{array}{l}\text { Number of } \\
\text { Times the } \\
\text { Whistle Was } \\
\text { Sounded. }\end{array}$ & $\begin{array}{l}\text { Pitch of the } \\
\text { Whistle. }\end{array}$ & Kind of Response. \\
\hline $\begin{array}{l}\text { I } \\
2 \\
3 \\
4 \\
5 \\
6 \\
7 \\
8 \\
9 \\
\text { I0 } \\
\text { I I } \\
\text { I } 2 \\
\text { I3 } \\
\text { I } 4 \\
\text { I } 5 \\
\text { I6 } \\
\text { I } 7 \\
\text { I } 8 \\
\text { I9 } \\
20 \\
2 \text { I } \\
22 \\
23 \\
24 \\
25-35 \\
36 \\
37 \\
38-43 \\
44\end{array}$ & $\begin{array}{l}\mathrm{I} \\
\mathrm{I} \\
\mathrm{I} \\
\mathrm{I} \\
\mathrm{I} \\
\mathrm{I} \\
\mathrm{I} \\
\mathrm{I} \\
\mathrm{I} \\
\mathrm{I} \\
\mathrm{I} \\
\mathrm{I} \\
\mathrm{I} \\
\mathrm{I} \\
\mathrm{I} \\
\mathrm{I} \\
\mathrm{I} \\
\mathrm{I} \\
\mathrm{I} \\
\mathrm{I} \\
\mathrm{I} \\
\mathrm{I} \\
\\
\mathrm{I} \\
\mathrm{I} \\
\mathrm{I} \\
\mathrm{I} \\
\mathrm{I}\end{array}$ & $e^{5}$ & $\begin{array}{l}\text { Made quivering movements with its } \\
\text { wings. } \\
\text { Ditto. } \\
\text { Ditto. } \\
\text { Ditto. } \\
\text { Ditto. } \\
\text { Ditto. } \\
\text { Ditto. } \\
\text { Flew (It saw the whistle). } \\
\text { Whole body quivered. } \\
\text { Ditto } \\
\text { Ditto. } \\
\text { Ditto. } \\
\text { Ditto. } \\
\text { Ditto. } \\
\text { Ditto. } \\
\text { Ditto. } \\
\text { Ditto. } \\
\text { Ditto. } \\
\text { Ditto. } \\
\text { Ditto. } \\
\text { Ditto. } \\
\text { Ditto. } \\
\text { Moved antennæ gradually forward and } \\
\text { then flew. } \\
\text { Body quivered. } \\
\text { Ditto. } \\
\text { Flew. } \\
\text { Whole body quivered. } \\
\text { Ditto. } \\
\text { Moved its antennæ four times and then } \\
\text { flew. }\end{array}$ \\
\hline
\end{tabular}


TABLE IX.

RESPONSES OF Catocala robinsoni to Sound.

\begin{tabular}{c|c|c|c}
\hline $\begin{array}{c}\text { Number of the } \\
\text { Experiment. }\end{array}$ & $\begin{array}{c}\text { Number of Times } \\
\text { the Whistle } \\
\text { Was Sounded. }\end{array}$ & $\begin{array}{c}\text { Pitch of the } \\
\text { Whistle. }\end{array}$ & Kind of Response. \\
\cline { 1 - 2 } I & I & Flew. \\
2 & I & Flew. \\
3 & I & Flew. \\
4 & Flew.
\end{tabular}

TABLE X.

RESPONSES of Catocala vidua to Sound.

\begin{tabular}{|c|c|c|c|}
\hline $\begin{array}{l}\text { Number of the } \\
\text { Experiment. }\end{array}$ & $\begin{array}{l}\text { Number of } \\
\text { Times the } \\
\text { Whistle Was } \\
\text { Sounded. }\end{array}$ & $\begin{array}{l}\text { Pitch of the } \\
\text { Whistle. }\end{array}$ & Kind of Response. \\
\hline $\begin{array}{l}\text { I } \\
2 \\
3 \\
4 \\
5 \\
6 \\
7 \\
8 \\
9 \\
\text { I0 } \\
\text { I } \\
\text { I } 2 \\
\text { I } 3 \\
\text { I } \\
\text { I } \\
\text { I } 6 \\
\text { I } 7 \\
\text { I } 8 \\
\text { I9 } \\
20\end{array}$ & $\begin{array}{l}\text { I } \\
\text { I } \\
\text { I } \\
\text { I } \\
\text { I } \\
\text { I } \\
\text { I } \\
\text { I } \\
\text { I } \\
\text { I } \\
\text { I } \\
\text { I } \\
\text { I } \\
\text { I } \\
\text { I } \\
\text { I } \\
\text { I } \\
\text { I } \\
\text { I } \\
4\end{array}$ & $a^{4}$ & $\begin{array}{l}\text { No response observed. } \\
\text { Flew. } \\
\text { Flew. } \\
\text { Flew. } \\
\text { Flew. } \\
\text { No response observed. } \\
\text { Ditto. } \\
\text { Ditto. } \\
\text { Ditto. } \\
\text { Ditto. } \\
\text { Ditto. } \\
\text { Flew (It saw the whistle). } \\
\text { No response observed. } \\
\text { Flew. } \\
\text { Flew. } \\
\text { No response observed. } \\
\text { Flew. } \\
\text { No response observed. } \\
\text { Flew. } \\
\text { Flew. }\end{array}$ \\
\hline
\end{tabular}

\section{TABle XI.}

Responses of Catocala vidua, Specimen Number 2, to Sound.

\begin{tabular}{|c|c|c|c|}
\hline $\begin{array}{l}\text { Number of the } \\
\text { Experiment }\end{array}$ & $\begin{array}{c}\text { Number of } \\
\text { Times the } \\
\text { Whistle Was } \\
\text { Sounded. }\end{array}$ & $\begin{array}{l}\text { Pitch of the } \\
\text { Whistle. }\end{array}$ & Kind of Response. \\
\hline I & I & $a^{4}$ & Moved its antennæ. \\
\hline 2 & I & & Flew. \\
\hline 3 & I & & Flew. \\
\hline 4 & I9 & & $\begin{array}{l}\text { Flew, but not until after the nineteenth } \\
\text { whistle. }\end{array}$ \\
\hline 5 & I & & Flew. \\
\hline 6 & 4 & & No response noticed. \\
\hline 7 & 4 & & No response noted. \\
\hline 8 & I & & Flew (Saw the whistle). \\
\hline
\end{tabular}


In June, I9I4, we made an attempt to see if, in the field, moths could be trained to respond to sounds to which they do not normally respond. We knew that this can be done in the laboratory. Our experience the year before had informed us that most Catocalæ do not respond to sounds of a low pitch. We selected an organ pipe giving 256 vibrations per second. This was sounded several times and if the moth did not respond it was sounded again and simultaneously one of us touched the moth with a brush. We then followed the moth to its next resting place and sounded it again, and if necessary, repeated it over and over.

For these experiments we used; C. amica, C. epione, C. neogamma, $C$. ilia, and $C$. innubens. With innubens and epione all results were negative. We found two specimens of ilia which responded to the sound of the pipe before they had been touched in any manner and one that did not so respond. This response from ilia was unexpected, but it militated against using it for these experiments. We succeeded in inducing one specimen of amica to respond to the pitch; but failed completely with two others. We experimented with five specimens of C. neogama, all males. We induced three individuals of neogama to respond to the sound of the organ pipe; but failed with two others. Although the cases in which we succeeded in inducing the moths to respond to sounds to which they do not usually react are few, the fact that we did succeed in a few cases supports our contention that these insects respond only to sounds that have a life significance.

\section{Conclusions.}

I. Our field experiments demonstrate that several different species of Catocala moths respond to certain high pitched notes of the Galton whistle; but that they usually do not respond to sounds of low pitch, such as the rumbling of trains, etc.

2. Most specimens responded to those high notes by flying to a nearby tree; but some, and this was especially true of Catocala relicta, responded by making quivering movements with its wings.

3. The degree of responsiveness was not the same in all species. Among the least responsive were $C$. vidua and $C$. neogama; at the other extreme were $C$. flebilis, $C$. habilis, and $C$. robinsoni. 
4. We do not consider the failure of these moths to respond to certain sounds of low pitch a proof that they do not hear such sounds; indeed, we are inclined to believe that these creatures respond only to such sounds as have a life significance. Three things render this last assumption probable: (I) The fact that C. unijuga, which at first did not respond to whistling, did so readily after once a blast of air had been allowed to strike her body simultaneously with the sounding of the whistle; (2) that most of the natural enemies of these moths produce high pitched sounds and trains, and brass bands and other producers of low pitched or coarse sounds do not directly affect the survival of these moths; and (3) by carefully conducted field experiments, we were able to induce three specimens of $C$. neogama to respond to sounds to which the species does not usually react.

\section{REFERENCES.}

The following list is not intended to be a complete bibliography of the sense of hearing of insects. It contains only such articles as have been referred to in the body of this paper. An effort has been made, however, to include all papers treating of experiments upon the auditory powers of the Lepidoptera. If any such have been omitted, it is because they have escaped our notice.

\section{Adelung, Nicolai von,}

'92 Beitraege zur Kenntnis des Tibialen Gehörapparates der Locusten. Zs. f. wiss. Zool., Bd. LIV., s. 316-349; Pls. XIV-XV.

\section{Andrews, E. A.}

'I I Observations on the Termites of Jamaica. Jour. of Animal Behav., Vol. I., pp. I93-228.

\section{Buttel-Reepen,}

'oo Sind die Bienen Reflex-maschinen? Experimentelle zur Biologie der Honigbiene. Biol. Centrlbl., Bd. XX., s. 97-108, I30-I44, I 77-193, 209-224, 289-304.

\section{Deegener, P.}

'og Koennen die Schmetterlinge Hören? Natur, Leipzig, I909-Io, pp. I I I-I I 2. Fielde and Parker.

'04 The Reactions of Ants to Material Vibrations. Proc. Nat. Acad. Sci. Forel, A. Philadelphia, Vol. 56.

'03 Ants and Some of Their Instincts. Monist, Vol. XIV., pp. 33-66, I77-I94. 


\section{Graber, V.}

'75 Die Tympanal Sinnesorganen der Orthopteren. Denkschriften der K. Akad. der Wissensch, Wien.

'82 Die Chordotonal Sinnesorgane und das Gehör der Insecten. Archiv f. wiss. Anat., Bd. XX., XXI.

\section{Hamann, W.}

'og Haben Schmetterlinge Gehörsinn? Intern. Ent. Zs., Bd. III., pp. I4I, I44-I 46.

Heinrich, Rudolph.

'og Haben Schmetterlinge Gehörsinn? Entom. Plauderi. Intern. Ent. Zs., Bd. II., s. $275^{-277}$.

\section{Henson, V.}

'66 Ueber das Gehororgan von Locusta. Zs. f. wiss. Zool., Bd. XVI., h. 2.

Huber, P.

'ıo Recherches sur les Moeurs des Fourmis Indigènes. Paris.

Lee, A. B.

'83 Bemerkungen Ueber den Feineren Bau der Chordotonalorgane. Arch. f. Mikr. Anat., Vol. XXIII.

'85 Les Balancers des Dipteres. Rec. Zool. Suisse, Vol. II.

Leydig, Fr.

'55 Zum feineren Bau der Arthropoden. Mueller's Archiv f. Anat. u. Physiologie.

\section{Lubbock, Sir J.}

'8I Ants, Bees and Wasps, pp. 22 I-233.

Montgomery, Th. H.

'xо The Significance of the Courtship and Secondary Sexual Characters of Araneads. Amer. Nat., Vol. XLIV., pp. I5I-I 77.

\section{Omensetter, S.}

'I2 The Speech of Insects. Proc. Del. County Inst. Sci., Vol. VI., pp. I 2 I-I36. Radl, E.

'05 Ueber das Gehör der Insecten. Biol. Centrlbl., Bd. XXV., s. I-5.

\section{Richter, Otto.}

'og Koennen Schmetterlinge Hören? Intern. Ent. Zs., Bd. III., s. I24-I 26.

'ı Gesicht und Gehor bei den Schmetterlingen. Intern. Ent. Zs., Bd. IV., s. $42-43,45-47,5 \mathrm{I}-53$.

\section{Röber, I.}

'ro Gehörsinn bei Schmetterlingen. Zs. wiss. Insectenbiol., Bd. VI., s. 355.

\section{Rothke, Max.}

'og Zum Hörenvermögen der Schmetterlinge. Intern. Ent. Zs., Bd. III., s. I62-I64.

\section{Romanes, Geo. J.}

'76 Sense of Hearing in Birds and Insects. Nature, Vol. XV., p. I77.

'9r Mental Evolution in Animals, p. 86.

\section{Schaeffer.}

'o9 Besitzen Insecten Gehörsinn? Intern. Ent. Zs., Bd. III., s. 37-38.

Siebold, von.

'44 Ueber das Stimm und Gehörorgan der Orthopteren. Wiegmann's Archiv f. Naturgeschichte, Io Jahrg. 


\section{Stephan, J.}

'I2 Tonerzeugende Schmetterlinge. Natur, Munchen, Vol. III., pp. II7-II9.

'I2 Tonerzeugende Raupen und Puppen. Natur, Munchen, Vol. III., pp. $426-427$.

Turner, C. H.,

'o7 The Homing of Ants. Jour. of Comp. Neur. and Psy., Vol. V., 367-435.

Weld, LeRoy.

'99 The Sense of Hearing in Ants. Science, n.s., Vol. X., pp. 766-768.

Weinland, E.

'9I Ueber die Schwinger der Dipteren. Zs. f. wiss. Zool., Bd. LI.

Wheeler, W. M.

'ro The Ant, pp. 512-5I5. 



\section{BIOLOGICAL BULLETIN}

\section{SPERMATOGENESIS OF THE HORSE WITH SPECIAL REFERENCE TO THE ACCESSORY CHROMO- SOME AND THE CHROMATOID BODY.}

J. E. WODSEDALEK,

Zoölogy Department, University of IDAho.

Contents.

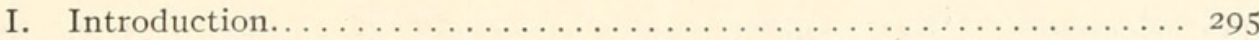

II. Material and Methods. . . . . . . . . . . . . . . . . . . . . . . 296

III. General Arrangement of the Germ Cells... . . . . . . . . . . . . . . . 297

IV. Spermatogonia................................ 297

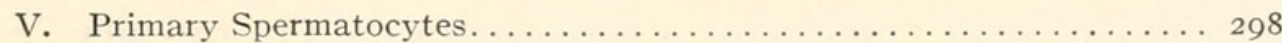

I. Resting Stage. . . . . . . . . . . . . . . . . . . . . . 298

2. Synizesis and Growth Period... . . . . . . . . . . . . . . . 299

3. Reduction Division. . . . . . . . . . . . . . . . . 300

VI. Secondary Spermatocyte....................

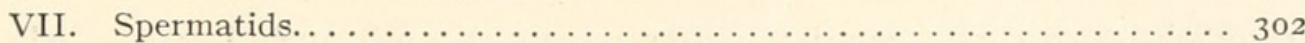

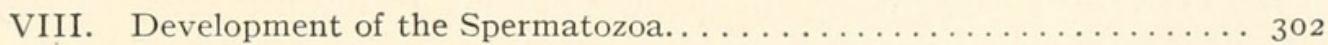

IX. Variation in Size of Adult Spermatozoa. . . . . . . . . . . . . . 305

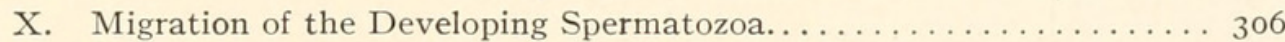

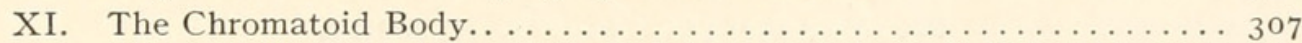

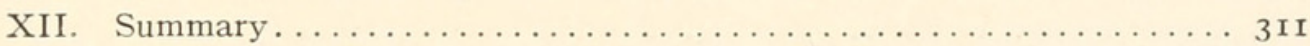

\section{Introduction.}

Many interesting things were observed in this study on the spermatogenesis of the horse, but the two points of especial interest and importance are; firstly, the occurrence of a large accessory chromosome, and secondly, the presence of a much smaller though very conspicuous body comparable to the chromatoid body as described by Professor E. B. Wilson ('13) in Pentatoma. While the significance of the chromatoid body is problematical, it is a body of extreme interest in this connection on account of its deceptive resemblance to an accessory chromosome. Were it not for the fact that its entire history can be 
followed out it might lead to serious misinterpretations. Since the occurrence of the chromatoid body in the horse is so constant and its behavior so distinct, and furthermore, since this is the first case among the vertebrates where such a body has been studied in full detail, it is dealt with at some length in this paper.

The significance of the accessory chromosome is of course obvious. It was shown beyond doubt that sex in the pig is determined by such elements (Wodsedalek,' I3). And while embryological material of the horse is not at present available to enable a similar extended study, the presence and unquestionable behavior of the accessory chromosome giving rise to a dimorphic condition among the spermatozoa of this mammal, nevertheless, lend additional support to the chromosome theory of sex determination. The spermatogenesis of the horse resembles to a certain extent the spermatogenesis of the pig (Wodsedalek, 'I3), and for the purpose of avoiding too much repetition it is treated in a comparative way in the present study.

This investigation was started in the zoölogical laboratory at the University of Idaho, but the main bulk of the work was done at the Wisconsin Biological Station at Madison. And I wish to thank the zoölogy department of the University of Wisconsin for the liberal use of their laboratories, apparatus and material, and the many other courtesies extended me during the summer of I9I4.

\section{Material and Methods.}

The material studied, mainly, was obtained from a horse about a year and a half old. Immediately after the testes were removed from the live animal, small pieces were placed in Bouin's and Gilson's fluids. Sections from various parts of the testes were made from four to ten microns thick, and the material fixed in Bouin's fluid and stained with Heidenhain's iron hematoxylin with acid fuchsin as a counterstain, as in the case of the pig, proved to be the most satisfactory.

Material from an animal about a year old was also studied; but while all the stages including the mature sperm could easily be identified in this material, the chromosomes were very difficult to count on account of being too closely aggregated or lumped 
together. The finer details of the cells, too, were not as easily made out as in the other material, this being undoubtedly due to the fact that the material was not fixed until about an hour after it was removed from the animal. The chromatoid body, however, was very distinct and could be traced throughout its entire history the same as in the more favorable material. The accessory chromosome, too, could easily be identified, especially through the first spermatocyte division.

\section{General Arrangement of the Germ Cells.}

The structure of the testes of the horse differs from the pig in that the seminiferous tubules as well as the corresponding cells in the various degrees of development are much smaller and the interstitial cells are much fewer in number. The continuous network of connective tissue walls is present, but the chambers formed by this network and filled with coiled tubules are much larger in the horse and, therefore, a section through one of the chambers as a rule reveals many more sections of the tubules. These chambers in the horse testes do not show the same regularity in size as is the case in the pig testes. In some cases a group of over a hundred sections through the tubules are surrounded by the connective tissue wall and then again a count of only a dozen or so can be made. The arrangement of the cells in the tubules is similar to that of the other wellknown mammals, particularly the pig.

\section{Spermatogonia.}

As a rule the spermatogonia lie in a single layer next to the wall of the tubule, though occasionally some of the cells are crowded out. At times the cells are far apart, in which case they are flattened out on the tubule wall. The cells also differ considerably in size and appearance, depending on the stage of development they are in (Figs. $\mathrm{I}-3$ ).

During the resting stages a large nucleolus is invariably present. As a rule it assumes a somewhat heart-shaped appearance; especially is this true in the larger cells and in those in which the chromosomes are beginning to form. A much smaller spherical nucleolus also appears to be fairly constant (Figs. I 
and 2). Other nucleoli varying considerably in size, shape, and number also appear in some of the cells (Fig. 2).

Before the chromosomes begin to form the cells increase greatly in size (Fig. 2). At the conclusion of the resting stage numerous large chromatin granules appear which arrange themselves along fine threads in an entangled mass. The chromosomes soon become distinct and while, as a rule, a count is impossible on account of the overlapping and massing together of the chromosomes, [the mitotic stages were abundant and many distinct counts could be made. Thirty-seven chromosomes appear in the late prophases of the spermatogonial division (Figs. 4 and 5). Thirty-six of these are variously shaped, mainly oblong, and differ somewhat in size. One which is much larger is, as a rule, somewhat triangular or heart-shaped. This is the accessory chromosome and is the same thing as the large nucleolus which appears in the resting stages. That is certain, as the body can easily be traced through the various stages of growth. This condition is similar to that found by Guyer ('Io) in man, and Wodsedalek ('I3) in the pig. Ordinarily about two thirds of the chromosomes arrange themselves in a ring which encircles the remaining one third. The accessory chromosome may be found anywhere within the mass, and occasionally occurs outside of the main ring, but never far removed from the other chromosomes. During division each chromosome divides in two. The accessory as a rule divides a little in advance of the other chromosomes (Figs. 6 and 7 ).

The spermatogonia in this, as well as other stages, vary somewhat in size (Figs. 6 and 7). In the smaller cells the cytoplasm appears denser and the chromosomes are more crowded together.

\section{Primary Spermatocytes. \\ I. Resting Stage.}

The primary spermatocytes arising from the final spermatogonial division in the early resting stage are usually smaller than the spermatogonia immediately preceding and during the division stages. After the disintegration of the chromosomes the nucleus appears much clearer than it does in the later growing stages. The large nucleolus is again very conspicuous and easy 
to distinguish from other nuclear bodies when such are present (Figs. 8-II). The small spherical nucleolus again appears to be fairly constant, though at times it is difficult to distinguish it from the other bodies.

\section{Synizesis and Growth Period.}

After a brief period of rest the cells begin to increase in size. For some time the nucleus appears much the same as it does in the resting stage of the spermatogonia (Fig. 8). Later it becomes more granular and the linin fibers become more distinct (Fig. 9). Soon after, the chromatin threads become massed in the center of the nucleus (Fig. Io), and later the nuclear wall expands and the entire mass passes to one side of the nucleus, leaving a large clear area in the remaining portion (Fig. II). This condition is much the same as in the pig except that in that animal the nucleoli were invariably found within the mass of threads and in a position nearest to the nuclear wall, while in the horse the nucleoli are almost invariably within, or next to the clear area (Fig. II). The nuclear wall in this stage is often very irregular, especially next to the clear portion of the nucleus.

Shortly after the collapse of the chromatin material, the threads pair and appear in about half the original number and twice as thick (Figs. IO-I2). There is considerable evidence that pairing of the threads takes place by parasynapsis, and nothing was observed which would indicate that it takes place otherwise; but this phase of the problem demands more study and no positive statement can be made in regard to it at this time. The entire mass of threads then moves toward the center and the large clear area disappears (Fig. I2). The large nucleolus passes toward the periphery of the nuclear wall and the threads soon become evenly distributed. Then follows the period of growth during which time both the nucleus and cytoplasm increase greatly in size (Figs. I3 and I4). The chromatin threads and the large nucleolus also increase considerably in size. It is between the synaptic stage and the fully developed spireme stage that the chromatoid body makes its appearance (Figs. I2-I4). 


\section{Reduction Division.}

Nineteen chromosomes appear in the late prophase or early metaphase stages of the primary spermatocyte (Figs. I5-I8). Eighteen of these are the ordinary chromosomes or autosomes and the other is the accessory chromosome. The accessory in this case is practically always found outside of the main mass of chromosomes, either in close contact with them (Figs. I6 and I 8), or a short distance away (Figs. I5 and I7). The large size of the eighteen autosomes which are about four times the size of the chromosomes in the spermatogonia indicates that they were formed by the growth and pairing of the thirty-six autosomes found in those cells, while the accessory remains unpaired, making a total of nineteen.

In these cells as in the case of the spermatogonia the chromosomes are frequently bunched together, making an accurate count difficult and often impossible. However, mitotic stages particularly of the first and second spermatocyte divisions were very numerous and among the thousands of cells in mitosis examined several hundred definite counts were made. Figs. I9-29 show the accessory in characteristic positions in the metaphases of division of the primary spermatocyte. The heartshaped body always passes toward one pole in advance of the other chromosomes and frequently may be found at the pole before the other chromosomes have divided (Figs. 28 and 29). The chromatoid body which is spherical in shape and much smaller than the accessory is also invariably present and very conspicuous. As a rule it is in the spindle, and in a large majority of the cases goes in the direction opposite from the accessory (Figs. 2I, 22, 23, 24, 25, 27 and 28), though this behavior is by no means constant, for occasionally it is found with the accessory on the same side of the equatorial plate (Figs. 20, 26 and 29).

When the large, apparently quadrivalent chromosomes divide, the resulting chromosomes are somewhat larger than the chromosomes of the spermatogonia. Immediately after the chromosomes divide they unite in twos (Fig. 29) so that at the time of their arrival at the poles they do not number eighteen, but only nine or exactly one half that number (Figs. 30-35). Additional proof that such a second pairing of the chromosomes occurs lies 
in the fact that the resulting nine chromosomes are not one half the size of the original eighteen chromosomes of these cells, but exactly of the same size and apparently quadrivalent. This quadrivalent nature becomes obviated after the division of the secondary spermatocyte, where the resulting chromosomes are bivalent. The primary spermtocyte division is undoubtedly the reduction division and, speaking in terms of univalence, one of the resulting secondary spermatocytes receives eighteen chromosomes and the other eighteen plus the accessory. In terms of bivalence the one type of secondary spermatocytes receive nine chromosomes and the other nine plus the accessory (Figs. 30-33).

\section{Vi. Secondary Spermatocyte.}

No resting stage occurs in the secondary spermatocyte, a condition similar to that frequently found in the spermatogenesis of the pig. The second pairing of the chromosomes also takes place here as it does in the pig (Wodsedalek, 'I3), man (Guyer, 'Io), and opossum (Jordan, 'II). In the pig, however, this pairing takes place much later, never before the cell is completely divided. The secondary spermatocytes divide soon after they are formed and not infrequently the spindles are formed in the two cells resulting from the first spermatocyte division while they are still in close contact. Nine chromosomes arrange themselves in the equatorial plate for division in the one type of secondary spermatocyte (Figs. 42-45), and nine plus the accessory in the other (Figs. 34-38). All of the chromosomes, including the accessory when it is present, divide in these cells (Figs. 36-47). The accessory usually lies a little to one side of the other chromosomes (Figs. 34 and 35), and again, as in the spermatogonia, divides a little in advance of the other chromosomes (Figs. 36-38). This may be due to the partial separation of the two halves of this body even long before the other chromosomes line up for division in this stage (Figs. 2I-33). The heartshape it assumes during the later stages of the primary spermatocyte division and retains during the secondary spermatocyte, is no doubt due to a partial separation at one end of the two components. The chromatoid body remains very conspicuous (Figs. $35^{-55) .}$ 


\section{Spermatids.}

The division of the secondary spermatocytes gives rise in the one case to spermatids containing nine chromosomes (Figs. 46, 55 and 56 ), and in the other case nine plus the one accessory or ten chromosomes (Figs. 39-4I). All of the chromosomes except the accessory are bivalent in nature (Figs. 23-4I, 54-56), so that in reality we have the equivalent of eighteen chromosomes in the one kind of spermatid and eighteen plus the accessory in the other. All of the foregoing evidences indicate that eighteen is the reduced number of chromosomes.

The accessory is usually out of the main mass of chromosomes (Figs. 40 and 4I). Soon after the secondary spermatocyte divides the chromosomes become massed together and the nuclear wall begins to form (Figs. 57-59). In the resting stage half the spermatids contain a large nucleolus which is the same thing as the accessory chromosome, since it can be traced through all the stages in the formation of the nucleus (Figs. 63-65). The other half of these cells lack such a body (Fig. 62). In some cases this nucleolus persists in the developing stages of the spermatozoön (Figs. 72 and 73). Especially is this true in material which has not been destained too much. In favorably stained material the centrosome surrounded by a clear layer can be seen within the centrosphere (Figs. 64-66). The chromatoid body is still very distinct (Figs. 55-67).

\section{ViII. Development of the Spermatozoa.}

The development of the spermatozoön in the horse is essentially the same as the development of the spermatozoön in the pig (Wodsedalek, 'I3). The centrosome surrounded by a clear area emerges from the sphere (Fig. 67) and soon divides into two spherical bodies (Fig. 68). The anterior one comes in contact with the nuclear wall, while the posterior one which remains spherical passes down the developing axial filament (Figs. 69, $70,7 \mathrm{I}, 73,74)$. This posterior body which is quite small never assumes the shape of a ring as it does in the pig. It passes far down the filament and often no trace of it is left (Fig. 79). Then again it retains a size just enabling detection (Fig. 73). As a rule, however, a sufficient amount of it is left to be sloughed off 
as in the case of the pig (Figs. 74, 75, 77 and 84). The chromatoid body is, in rare cases however, also seen on the filament and in such cases apparently fused with the posterior centrosome (Figs. 7I and 76). It is invariably sloughed off before the spermatozoön is fully developed (Figs. 77 and 86).

Shortly after the centrosome divides the nucleus begins to elongate and at the same time migrates toward one end of the cell, so that soon practically all of the cytoplasm is found at the posterior end of the developing sperm (Figs. 67-75). As the acrosome-end of the nucleus comes in contact with the cell-wall no break in the latter is ever noticeable, and the apparent backward pull exerted by the mass of cytoplasm causes the cellwall to become closely applied to the nuclear wall where it undoubtedly persists as an additional covering of the spermhead (Figs. 73-79). This supposition that the cell-wall forms an additional covering of the sperm-head is based on two observations; firstly, there is no evidence that the head penetrates the cell-wall, and secondly, the covering of the sperm-head is much thicker after the entire mass of cytoplasm lies at its posterior end (Figs. 73-79). This fact gives one the impression that the distinctly noticeable change in the thickness of the head covering is brought about by the fusion of the two walls. It is also obvious that the cell-wall is not entirely consumed in forming the external covering of the head of the sperm, for it can always be seen surrounding the anterior portion of the axial filament and extending far down into the mass of cytoplasm which is apparently squeezed out of it and about to be thrown off (Figs. 77-79). In the final stages it becomes closely applied to the axial filament and one may safely conclude that the axial envelope is at least partly formed by the portion of the cell-wall extending down from the head (Figs. 77, 79 and 85). This same condition was found to exist in the pig.

When the developing sperms reach the stage represented in Fig. 73 they become attached in clusters to the large nurse cells. As the sperms develop the cytoplasmic mass of the nurse cells decreases. Just as the mass of cytoplasm is being thrown off by the developing spermatozoa, the latter leave the nurse cells and become embedded in the layer of cytoplasm composed of the 
cast-off masses, apparently nursing on the material so that little of it, if any, goes to waste.

Every stage in the sloughing off of the cytoplasmic mass can easily be observed (Figs. 77-86). When these masses of naked cytoplasm are completely sloughed off they assume a rounded shape and if the chromatoid body is present they might, at first sight, be mistaken for minute cells with the chromatoid body as the nucleus. And I feel that Wilson ('I3), in speaking of this condition in Pentatoma, is absolutely correct when he says, "I also think it probable that the bodies that have been described as 'degenerating cells' in the late spermatid-cysts by some observers are identical with the protoplasmic balls here described."

Among the cast-off balls four different types can be observed (Figs. 80-83). One type contains a small body which apparently is the remnant of the posterior centrosome (Fig. 80); another type is clear and one is led to believe that in such a case the centrosome was entirely consumed (Fig. 8I); another shows the same condition regarding the small body but contains the chromatoid body (Fig. 86); and still another contains both the chromatoid body and the much smaller centrosome remnant (Fig. 82). Later when the spermatozoa are fully developed the roundish masses become irregular in shape and finally begin to disintegrate. The disintegration is characterized by the breaking-up of the masses into small particles and by the appearance of many deeply staining bodies and globules which vary considerably in size (Fig. 83).

Occasionally in the last stages of the disintegration of the cytoplasmic material and also when the material entirely disappears there may be seen small, deeply staining bodies identical in size and appearance to the chromatoid body and one is led to believe that it is the same thing (Figs. 83 and 84 ). If it is the same thing the fact throws some light on its durable consistency.

The mature spermatozoön in general resembles that of the pig, except that it is smaller, and the head is thinner at the anterior end and thicker at the posterior end. The entire nucleus enters into the formation of the head and the contents become homogeneous and intensely staining. 
IX. Variation in Size of Adult Spermatozoa.

The spermatozoa of the horse like those of the pig vary considerably in size and many careful measurements show that they, too, are of two distinct types, the one being much larger than the other. Mature specimens which were free in the lumen of the tubule and parallel to the objective, were selected at random and outline sketches of six hundred heads enlarged $\left(X_{2}\right.$,ooo) were made with the aid of a camera lucida. The lengths of the sketches were then measured and recorded in quarter millimeters. It can be seen from Fig. I in the text that two separate types of

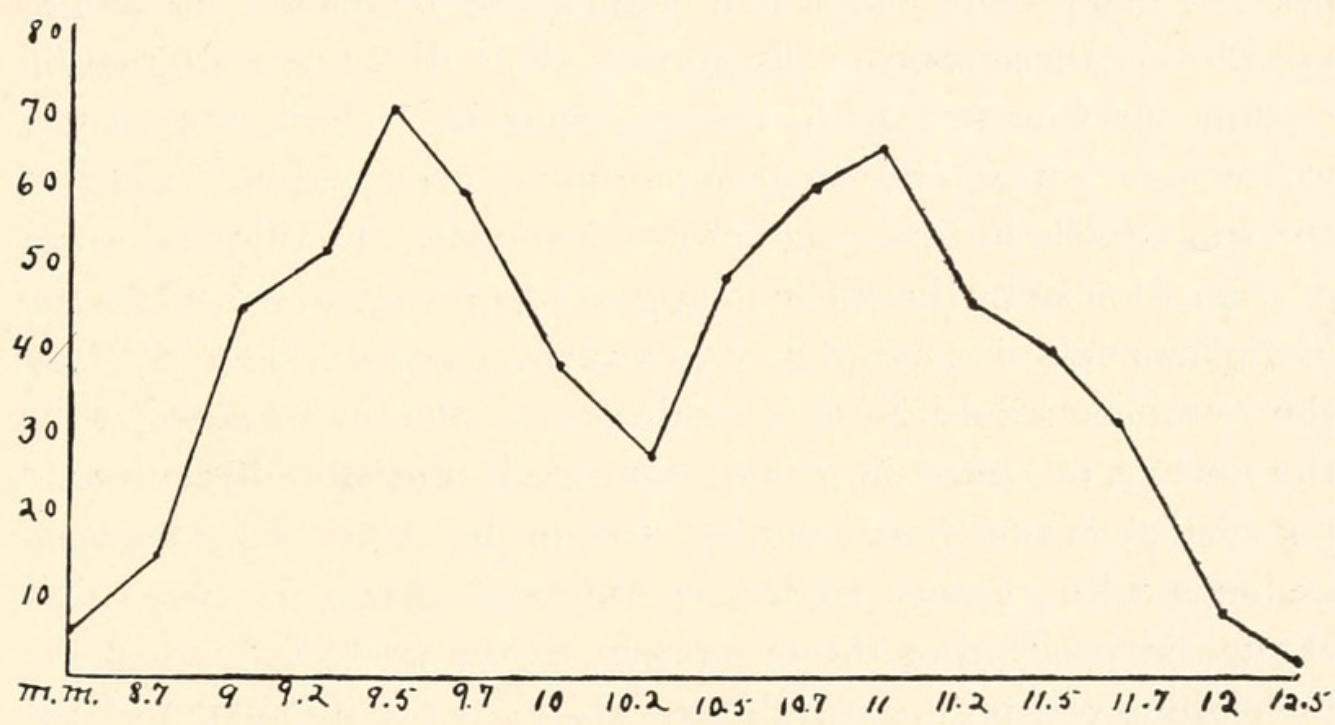

FIG. I. Diagram showing the variation in size among six hundred mature horse spermatozoa. Figures at the left give the numbers of individuals belonging to each type. Figures at the bottom give the lengths of the heads of the spermatozoa in millimeters, magnified two thousand times.

spermatozoa exist; the greatest number of the one kind measuring $9.5 \mathrm{~mm}$., and of the other I I mm. I think it is safe to assume that this dimorphic condition in the size of the mature spermatozoa is due to the accessory chromosome. The increased size in the one type is due presumably to the presence of that element.

A similar dimorphic condition was found to exist among the spermatozoa of the pig; one type measuring from I I to I $2 \mathrm{~mm}$., and the other from I4 to I $4.5 \mathrm{~mm}$. (Wodsedalek, 'I3). Size dimorphism also exists in the adult spermatozoa of Anasa tristis (Faust, 'I3). This of course is exactly what would be expected 
since the spermatogenesis studies of this form indicate that one half of the spermatozoa receive one more chromosome each than the other half (Paulmier, '99).

\section{Migration of the Developing Spermatozoa.}

In the very beginning of the transformation of the spermatids into spermatozoa when the acrosome takes a position on the nucleus opposite the dividing centrosome (Fig. 68), the anterior end of the sperm-cell which bears the acrosome, invariably points in the direction of the tubule wall and the Sertoli or nurse cells. Long before the tail is sufficiently developed to aid in locomotion these sperm-cells move a short distance and come in contact in bunches with the nurse cells. There apparently exists some attraction between the nurse cells and the nuclei of the sperm cells in that stage of development. In this first stage of migration only the nucleus appears to be attracted while the cytoplasm exhibits a tendency to remain in place. The fact that the cytoplasm does have a tendency to remain in place while the nucleus or sperm-head moves forward undoubtedly accounts for the posterior position that the entire mass of cytoplasm assumes with respect to the sperm-head (Figs. 69-79). This change in position of the cytoplasm to the posterior end of the developing cell occurs simultaneously with the migration of the cell, which is further evidence for such an assumption. The nucleus is apparently attracted with sufficient intensity to enable it to pull the entire cytoplasmic contents after it to a certain extent. In the later stages the movement of the sperm-head deeper into the cytoplasm of the nurse-cell is probably facilitated by the flagellum-like motion of the filament which extends a considerable distance out of the cell (Figs. 75-79). Later, when the spermatozoa are almost fully developed and slough off the balls of naked cytoplasm (Figs. 85 and 86) they back out away from the nurse-cells, becoming embedded in the cast-off material where they remain scattered until they are fully developed and then become free in the lumen of the tubule. This indicates that the sperms in that stage of development are attracted more by their own thrown-off material than by the rather scanty contents of the nurse cells, which are then very 
much collapsed, owing to the large number of developing sperms which they have nourished. This migration of the sperm backward is probably nothing more than a chemotactic response to the food contained in the balls of cytoplasm.

\section{The Chromatoid Body.}

The behavior of the chromatoid body in the horse bears a striking resemblance to the behavior of the chromatoid body described in Pentatoma (Wilson, 'I3). Dr. Wilson treats the subject at considerable length in his paper and therefore much of the detail concerning this body in the horse may safely be omitted. However, all the more essential features will be presented here since this is the first case among the vertebrates, according to my knowledge, where such an element has been studied in full detail. The reader is advised to familiarize himself with Professor Wilson's article in order to appreciate fully the surprising similarity existing in the behavior of the chromatoid body in such diverse classes of animals as the insects and the mammals.

In speaking of the chromatoid body Professor Wilson ('13) says in part, "As seen during the growth-period and the spermatocyte-divisions it is of rounded form, dense and homogeneous consistency, and after double staining with hæmatoxylin or safranin and light green is at every stage colored intensely blueblack or brilliant red, precisely like the chromosomes of the division-period or the chromosome-nucleoli of the growth-period. In the first spermatocyte-division it may lie anywhere in the cell, sometimes almost at the periphery, but is often close beside the chromosomes. In the latter case it usually lies in, on or near the spindle, lags behind the chromosomes during the anaphases, and in later stages is found near one pole, presenting an appearance remarkably like that of an accessory chromosome (Figs. 8-Io). For such in fact I mistook it, even after the discovery that a similar body is often also seen near one pole in the second division (Figs. 22, 23); for I supposed this might be a case like that of Ascaris megalocephala, where, according to Edwards ('Iо) the $X$-chromosome may pass undivided to one pole in either the first or second division. The resemblance is indeed most deceptive; and these division-figures have often been exhibited to 
other observers as "a remarkably clear demonstration of an accessory chromosome" without at first arousing the least suspicion of the hoax.

"The body in question is nevertheless neither an accessory nor any other kind of chromosome; though this did not become wholly certain until after a study of the entire spermatogenesis. It is in fact of protoplasmic origin, first appearing early in the growth-period outside the nucleus, whence it may be followed uninterruptedly through all the succeeding stages until it is finally cast out of the spermatozoön. Upon dissolution of the nuclear membrane it is left lying near the chromosomes, passes without division into one of the daughter-cells in each of the spermatocyte-divisions, and thus enters but one fourth of the spermatids."

In the horse the chromatoid body is of a spherical shape and also of a dense and homogeneous consistency, and stains exactly like the chromosomes of the division stages or the chromosomenucleoli of the growth-period. It is invariably surrounded by a clear area. It makes its appearance in the stages immediately following synizesis and apparently attains its full size rather abruptly, for as a rule even in the earlier growing stages, if it is present at all, it possesses its full size, although in some cases it was found to be somewhat smaller (Fig. I3). Occasionally, in the earliest stages immediately following synizesis one or two very small bodies within clear vacuoles could be detected (Fig. I2). Two such small bodies are extremely rare and even the single minute bodies showing the very beginning of the chromatoid body are not numerous; however, it is quite certain that the body practically always originates as a single element. When the cells attain their maximum size the chromatoid body is invariably present and possesses its full size which makes it very conspicuous (Fig. I4).

The chromatoid body may be seen anywhere within the cytoplasm, either near the nucleus or far from it. Sometimes it appears to be in fairly close contact with the cell-wall (Fig. I4). When the nuclear wall disappears and the chromosomes come into full view, it may again be found anywhere in the cytoplasm. Later when the chromosomes arrange themselves for division 
in the equatorial plate it most generally takes a position near them (Figs. I5 and I8), and when the spindle is formed, in a large majority of the cases, it takes a position in, on or near the spindle (Figs. $2 \mathrm{I}-28$ ) as is the case in Pentatoma (Wilson, 'I3). This, however, is not always the case, for occasionally it is far away from the spindle (Figs. 20 and 29).

It was in the primary spermatocyte division that the chromatoid body was first observed. It attracted my attention at the very first glance at the material under low power of the microscope and its constant appearance in this stage led me to suppose, at first, that it may be an accessory chromosome. Soon, however, the large, heart-shaped accessory was discovered and for some time I had the impression that this was the $X$-chromosome and the small spherical body the $Y$-chromosome. This temporary, erroneous impression was obtained through the peculiar fact that in about ninety per cent. of the cases the chromatoid body passes over to the half of the dividing cell opposite from that containing the large accessory, and in almost a hundred of the first mitotic stages examined not a single case was noticed in which the spherical body was on the same side of the equatorial plate with the accessory chromosome. Even when the first case in which both of the bodies were seen on their way to the same pole was observed, the matter was not taken very seriously. Later, however, when more such cases were seen, my suspicion was aroused and further observations convinced me that besides the supposed $y$-chromosome a body identical to it was present. And it was not until the entire history of the body could be traced from the growth-period to the casting-off of the mass of cytoplasm in the final stages of the developing spermatozoön, that I was absolutely certain that the suspicious looking element and the supposed $y$-chromosome were one and the same thing, namely, the chromatoid body, first described by Wilson in insects.

In exceptionally rare cases, one (Figs. 23 and 26) or two other small, deeply staining bodies within clear vacuoles occur in the cytoplasm (Fig. 27). However, in cases where such bodies do occur, there is no appreciable difference in the size of the chromatoid body and therefore it is difficult to determine whether such bodies are simply portions split off from the chromatoid 
body, or whether they originate separately. In only three cases did I observe two bodies apparently of equal size and smaller than the profoundly constant chromatoid body (Fig. 54). Were such cases more numerous one might assume that such bodies are the components of the chromatoid body, but since such bodies are of such extremely rare occurrence no definite statement can be made in regard to them.

When the primary spermatocyte divides the chromatoid body is practically always found in only one of the resulting cells (Figs. 30-33) and in a large majority of the cases it is found in the cells which do not contain the accessory chromosome (Figs. 30, 3I and 33). This, however, is not universal, for in some cases at least, it is found in the same cell which contains the accessory (Figs. 32 and 35); and it has also been seen in the division stages of such a type of secondary spermatocyte (Figs. 38 and 39) as well as in the spermatid resulting from such a division (Fig. 4I). In the anaphase of the secondary spermatocyte division the body is usually seen lagging on the spindle threads behind the masses of chromosomes (Figs. 39, 48, 49, 5I and 52); occasionally, however, it is seen at the pole (Fig. 5I). After the division is complete the body usually lies far out in the cytoplasm (Figs. 4I and 57), and in rare cases only, is it seen in close contact with the nucleus. Figure $5^{8}$ represents an extreme case of that nature, and it appears that such a condition is brought about when the chromatoid body bears a relation to the chromosome as is represented in Fig. 5I. Sometimes two bodies (Fig. 60), though not always of the same size, appear in the spermatid.

In the late resting stages of the spermatid the body may again be found anywhere in the cytoplasm (Figs. 62-67), at times near the nucleus (Fig. 62). Sometimes it is found in close contact with the centrosome (Figs. 63 and 66) and in only rare cases it is found on the axial filament, giving the impression that it is fused or in close contact with the posterior centrosome (Figs. 72 and 76). Later, however, it leaves the filament and lies freely in the cytoplasm (Figs. 74, 75, 77, 86). In the final stages of the developing spermatozoön when the cytoplasmic mass is cast off, the chromatoid body when present is invariably thrown off with it (Figs. 82 and 86). It is certain that the chromatoid 
body does not contribute in any visible way to the formation of the spermatozoön. The foregoing facts also indicate that great care must be exercised in interpreting the significance of bodies which appear like chromosomes, but really are something entirely different and no positive statements can be made regarding their meaning unless their entire history can be definitely traced.

It is very probable that a body similar to the chromatoid body in the horse also exists in the pig. In speaking of a small chromatin body which frequently occurs in the first spermatocyte division of the pig (Wodsedalek, 'I3), I make the following statement: "Occasionally a small chromatin body is present in this first spermatocyte division (Figs. 28, 3I, 32, 35 and 37). Fig. 3I shows such a body passing to the same pole with the accessories, in advance of the other chromosomes. Fig. 32 represents an earlier stage of much the same thing. In Fig. 35 it can be seen passing to the opposite pole, and Fig. 37 represents an extremely rare case where two such bodies are present, one somewhat larger, passing to either pole, even in advance of the two accessory chromosomes. While the small body can be seen frequently, as a rule no such element can be detected, and while it may possibly be comparable to the small pair of chromosomes found so constantly in some of the Tracheata, my present data on its irregular occurrence and behavior do not permit a conclusion regarding its significance."

Further investigation regarding the body in question in the pig will be taken up presently. It might also be mentioned here that the chromatoid body is present in the germ-cell of the bull. A complete account of its behavior in that animal will be published later.

\section{Summary.}

I. Thirty-seven chromosomes differing somewhat in size occur in the spermatogonia. One, the accessory, is distinctly larger than the others.

2. In the spermatogonial division the accessory divides a little in advance of the other chromosomes.

3. Nineteen chromosomes appear in the primary spermatocyte division, of which eighteen are evidently bivalent and the other is the accessory. 
4. In the secondary spermatocyte division the heart-shaped accessory passes undivided to one pole in advance of the other chromosomes.

5. The primary spermatocyte division is evidently the reduction division, giving rise to two different types of secondary spermatocytes; one with the accessory and the other lacking it.

6. There is no resting stage following the first spermatocyte division.

7. A second pairing of the chromosomes takes place so that only one-fourth the original number of chromosomes appear for division in the secondary spermatocyte.

8. The accessory chromosome divides in the secondary spermatocyte division a little in advance of the other chromosomes the same as it does in the spermatogonia.

9. The one type of secondary spermatocyte, which contains the accessory, gives rise to two spermatids, each containing the accessory and nine bivalent chromosomes.

Io. The other type of secondary spermatocyte, which lacks the accessory, gives rise to two spermatids, each containing only the nine bivalent chromosomes.

I I. In terms of univalence, then, one type of spermatid receives eighteen chromosomes plus the accessory and the other type receives only the eighteen ordinary chromosomes.

I2. In view of the foregoing facts, two different types of spermatozoa, equal in numbers, are produced in the horse; the one type contains in addition to the ordinary chromosomes the accessory, and is apparently the female determining spermatozoön.

I3. Actual measurements of six hundred mature spermatozoa reveal the interesting fact that two distinct types of spermatozoa as regards size are produced, the one being much larger and presumably the one which bears the accessory chromosome.

I4. The dimorphic condition among the spermatozoa of the horse lends additional support to the chromosome theory of sex determination.

I5. The developing spermatozoa invariably cast off a mass of cytoplasm.

I6. A chromatoid body, which simulates the appearance of a 
$y$-element in the primary spermatocyte division stages, makes its appearance during the growth period and can be traced forward until it is finally thrown off with the ball of cytoplasm in the developing spermatozoön. It does not contribute in any visible way to the formation of the spermatozoön.

Faust, E. C.

\section{LITERATURE CITED.}

'I3 Size Dimorphism in Adult Spermatozoa of Anasa tristis. Biol. Bull., Vol. XXV., No. 5, Oct., I9I3.

Guyer, M. F.

'io Accessory Chromosomes in Man. Biol. Bull., Vol. XIX., No. 4.

Jordan, H. E.

'II The Spermatogenesis of the Opossum (Didelphys virginiana) with Special Reference to the Accessory Chromosome and the Chondriosomes. Archiv für Zellforschung, 7. Band, I. Heft.

Paulmier, F. C.

'99 The Spermatogenesis of Anasa tristis. Jour. Morph., XV., supl., pp. 223272.

Wilson, E. B.

'I3 A Chromatoid Body Simulating an Accessory Chromosome in Pentatoma. Biol. Bull., Vol. XXIV., No. 6, May, I9I3.

Wodsedalek, J. E.

'I3 Spermatogenesis of the Pig, with Special Reference to the Accessory Chromosomes. Biol. Bull., Vol. XXV., No. I, June, I9I3.

'I3 Accessory Chromosomes in the Pig. Science, n.s., Vol. XXXVIII., No. 966, pp. 30-3I. 


\section{EXPLANATION OF PLATES.}

Plate I.

(All of the drawings were made with the aid of a camera lucida, $\times 2,400$.)

FIG. I. Early spermatogonial cell showing a large triangular nucleolus and two small nucleoli, one of which is spherical. Other cells in the same stage often show many more nucleoli.

FIG. 2. Resting stage of a full grown spermatogonial cell showing the large triangular nucleolus and several small nucleoli, one of which is spherical and can frequently be detected.

FIG. 3. Prophase of a spermatogonial division in which the chromosomes are still rather indistinct.

FIGS. 4 AND 5. Late prophase of spermatogonial division showing thirty-six ordinary chromosomes and the large accessory which can easily be distinguished.

Figs. 6 AND 7. Metaphase of division in a spermatogonium showing the accessory dividing in advance of the other chromosomes. In Fig. 6 the cell appears smaller and the chromosomes are more crowded.

FIGS. 8 AND 9. Early and late resting stages of a primary spermatocyte, respectively. Both show the large and the small nucleolus.

FIG. Io. Primary stage just before synizesis showing a mass of fine threads and the two nucleoli.

FIG. II. Primary spermatocyte in synizesis showing the nucleoli in a characteristic position out of the mass of threads.

FIG. I2. Primary spermatocyte following synizesis and synapsis. The threads scatter about in the nucleus.

FIGS. I3 AND I4. Spireme stage of a primary spermatocyte showing increase in size of the cytoplasm, nucleus and the large nucleolus, and the beginning of the chromatoid body. 

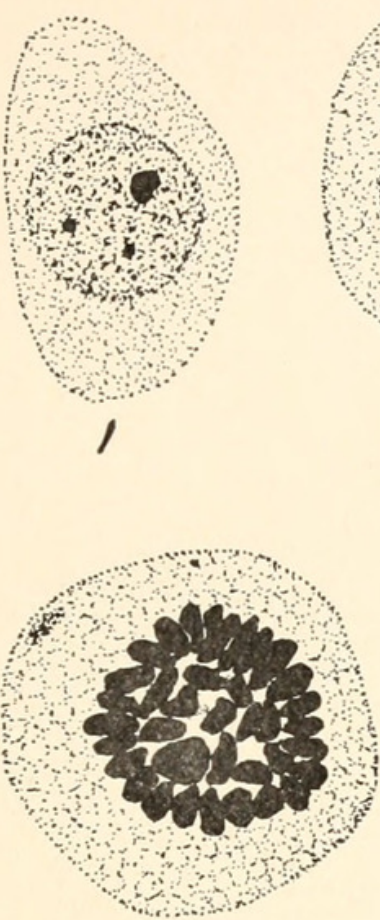

5

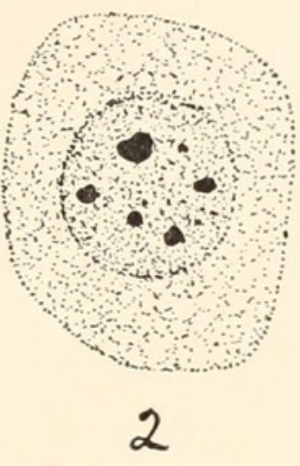

2
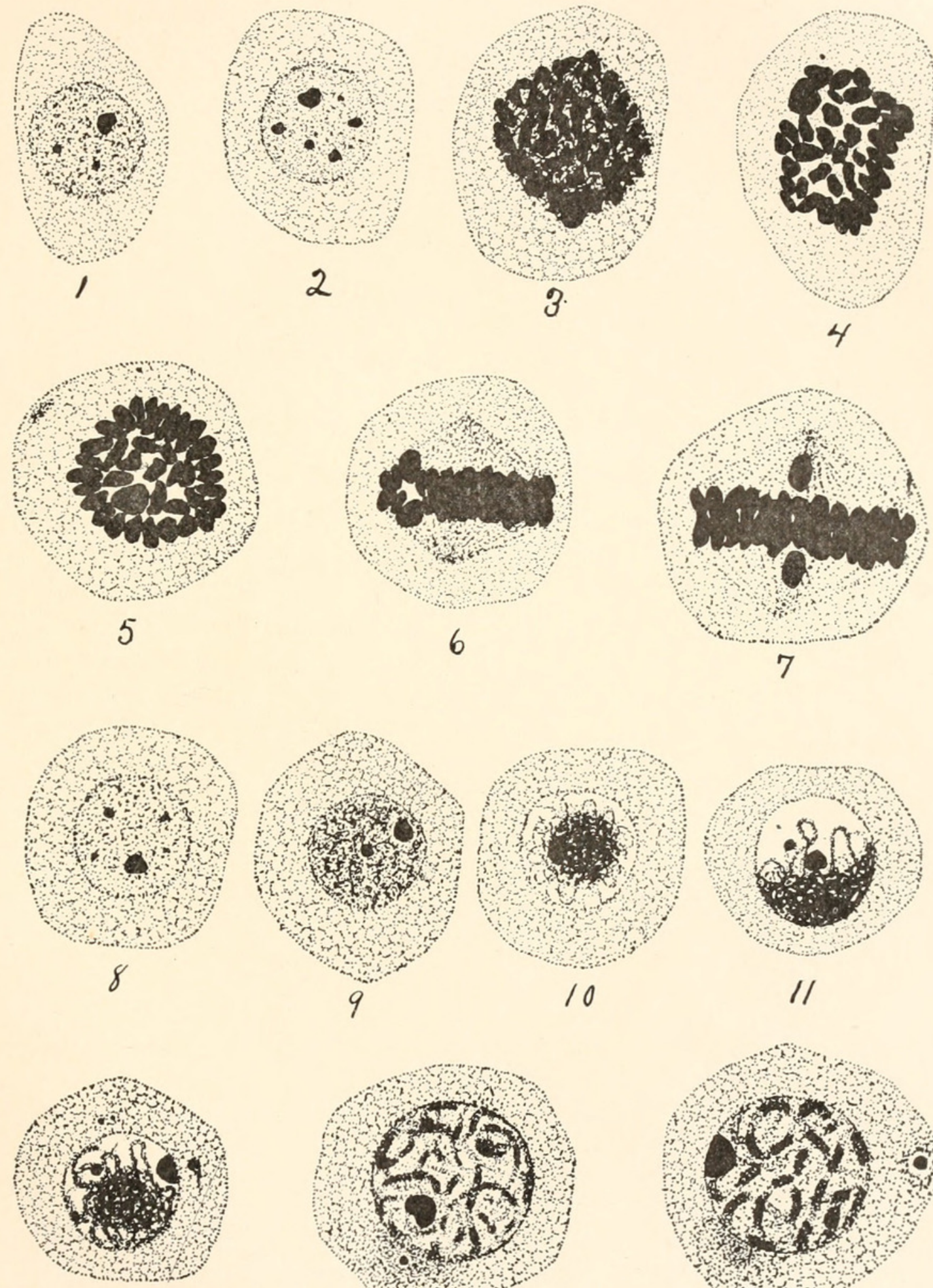

12
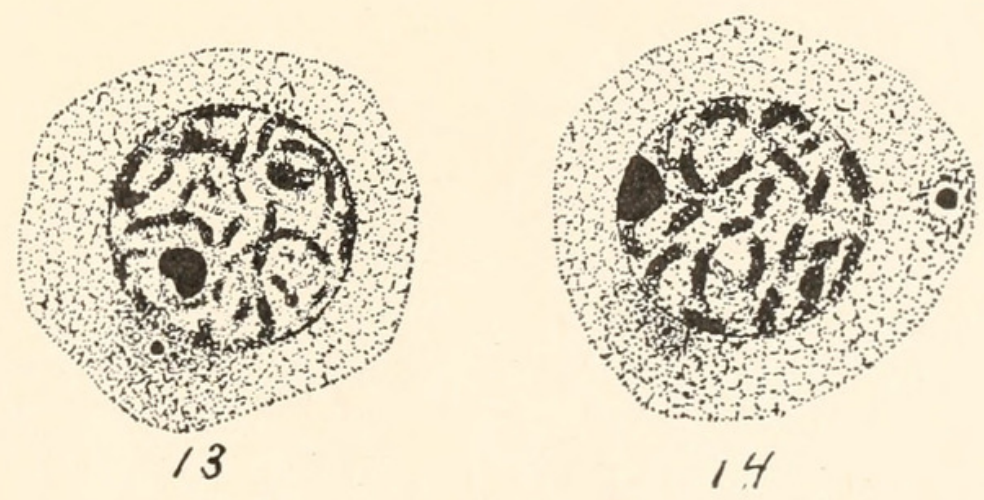

J. E. WODSEDALEK. 


Plate II.

FIGS. I5-I8. Late prophases of primary spermatocytes showing eighteen large chromosomes, the accessory a little off to one side and the conspicuous chromatoid body anywhere in the cytoplasm. Fig. I6 shows a characteristic bunch of chromosomes in which a count is impossible.

FIGS. 19-26. Metaphase of division in primary spermatocyte, showing the accessory chromosome in characteristic positions passing to the pole, and also the chromatoid body. Figs. 20 and 26 show the chromatoid body with the accessory on the same side of the equatorial plate. Figs. 23 and 26 show also an extra small body. 


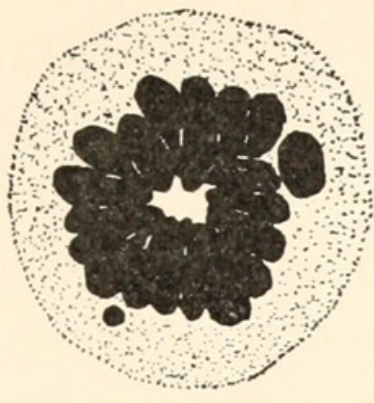

15
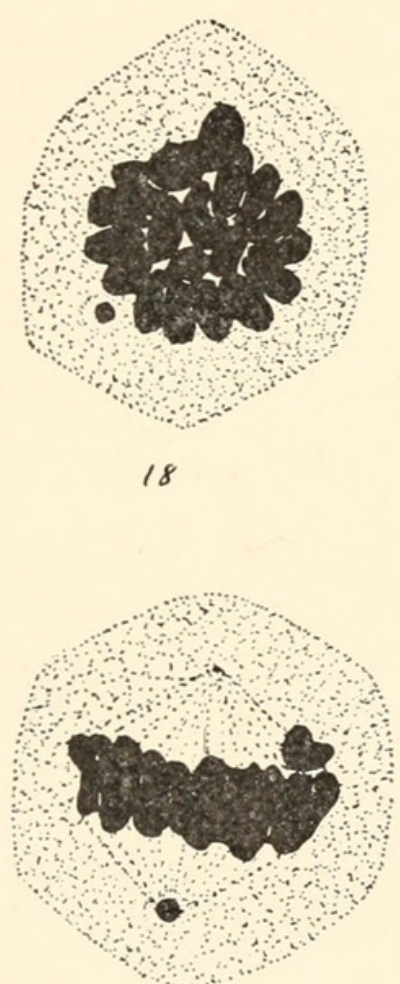

21

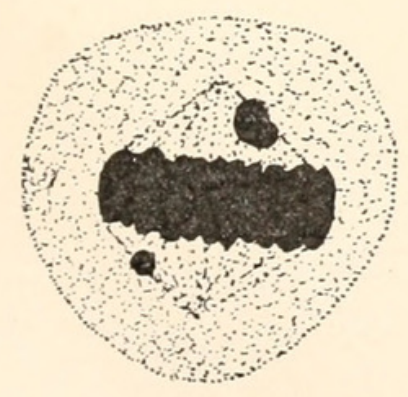

24

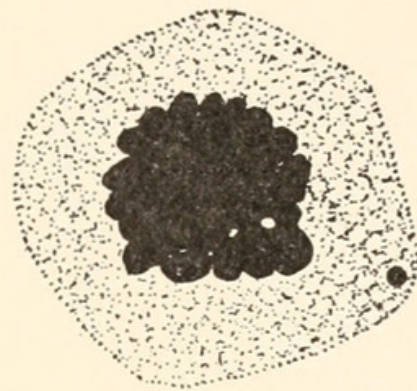

16
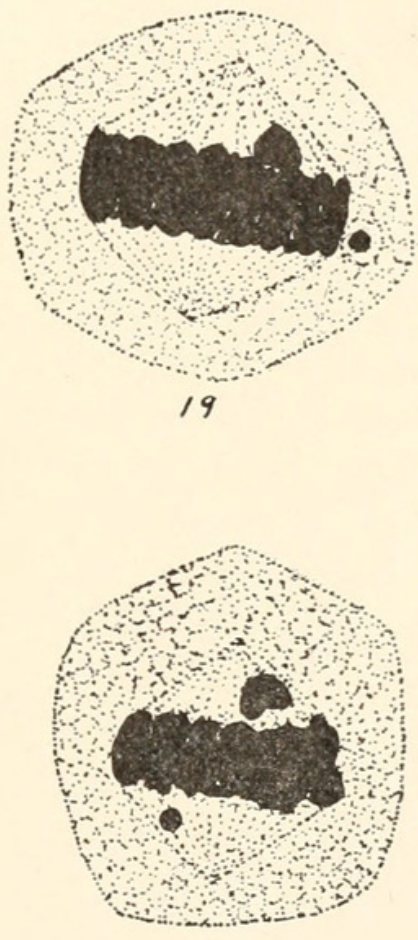

22

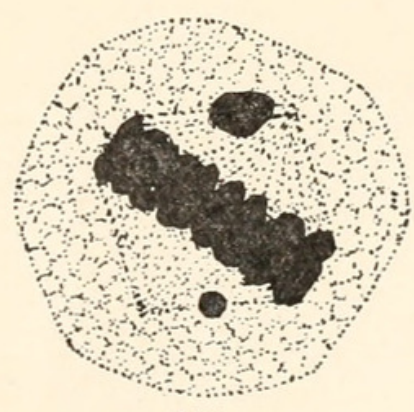

25
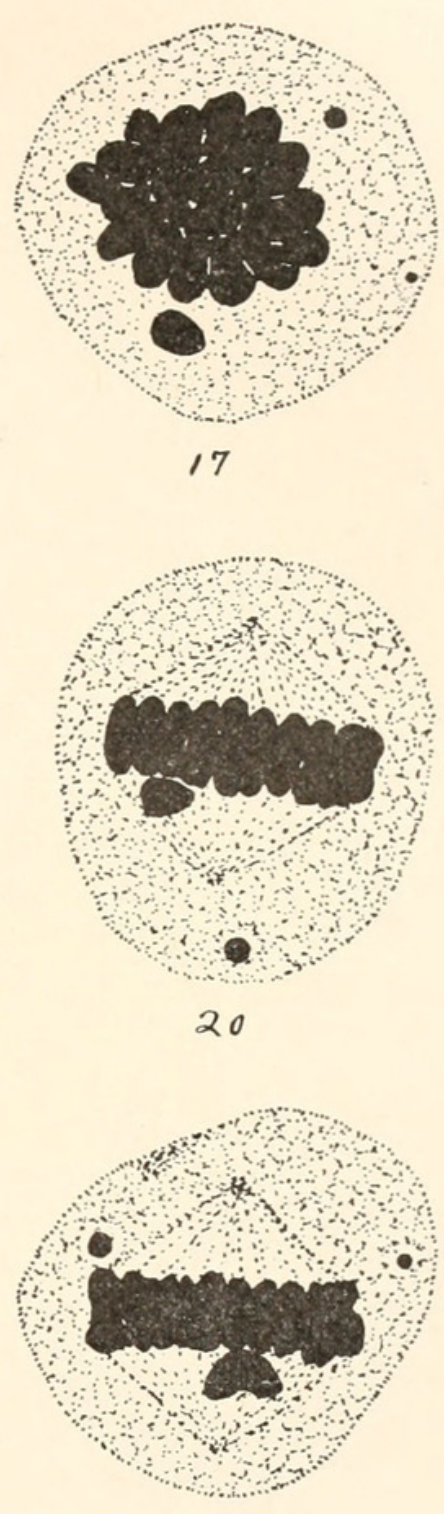

23

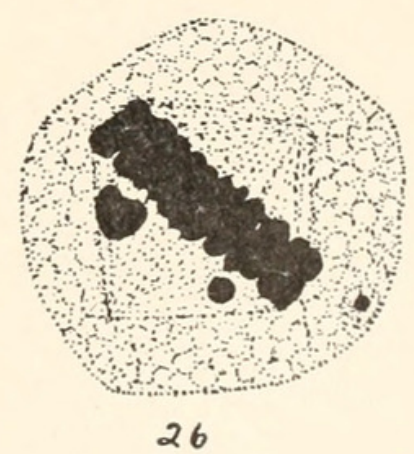

J. E. WODSEDALEK. 




\section{Plate III.}

FIGS. 27, 28, AND 29. Metaphase of division in primary spermatocyte showing the accessory chromosome and the chromatoid body. Fig. 27 shows two other small and deeply stained bodies. Fig. 28 shows the accessory at one pole and the chromatoid body at the other. Fig. 29 shows the accessory at the pole, and the chromatoid body off the spindle and near the periphery of the cell.

FIGS. 30 and 3I. Late anaphase of division in primary spermatocyte showing nine large chromosomes and the accessory at one pole, and nine large chromosomes and the chromatoid body at the other.

FIG. 32. Late anaphase of division in primary spermatocyte, showing nine chromosomes at one pole, and nine chromosomes, the accessory, and the chromatoid body at the other.

FIG. 33. Two resulting cells of a primary spermatocyte division, one containing the accessory chromosome and the other the chromatoid body.

FIGs. 34 and 35. Late prophase of division in a secondary spermatocyte which received the accessory chromosome. Cell represented in Fig. 35 also shows the chromatoid body.

FIGs. 36, 37, AND 38. Metaphase of division in the secondary spermatocyte showing the division of the accessory in advance of the other chromosomes. Fig. 38 also shows the chromatoid body near the periphery.

FIG. 39. Late anaphase of division in a secondary spermatocyte which received the accessory chromosome, nine apparently bivalent chromosomes and the large accessory can be seen at either pole and the chromatoid body is between the two masses of chromosomes.

FIgs. 40 AND 4I. Spermatid showing nine bivalent chromosomes and the accessories. Fig. 4I also shows the chromatoid body. 


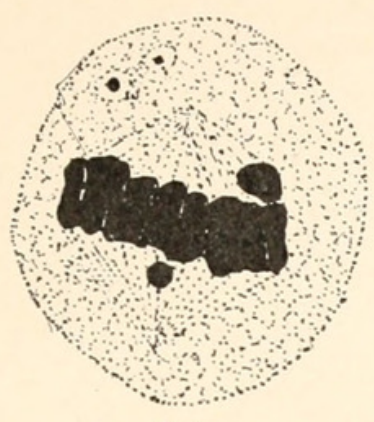

27
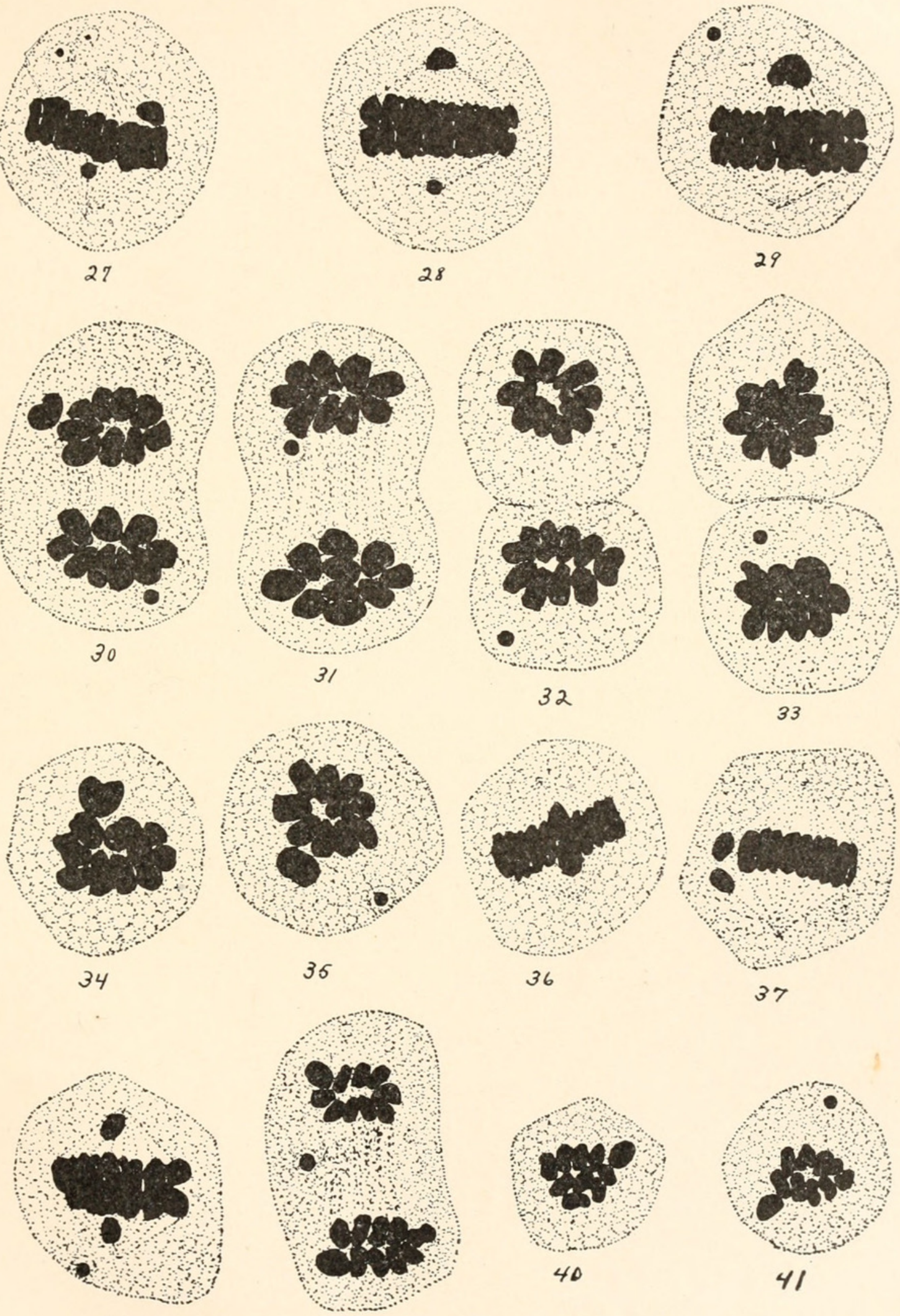

38
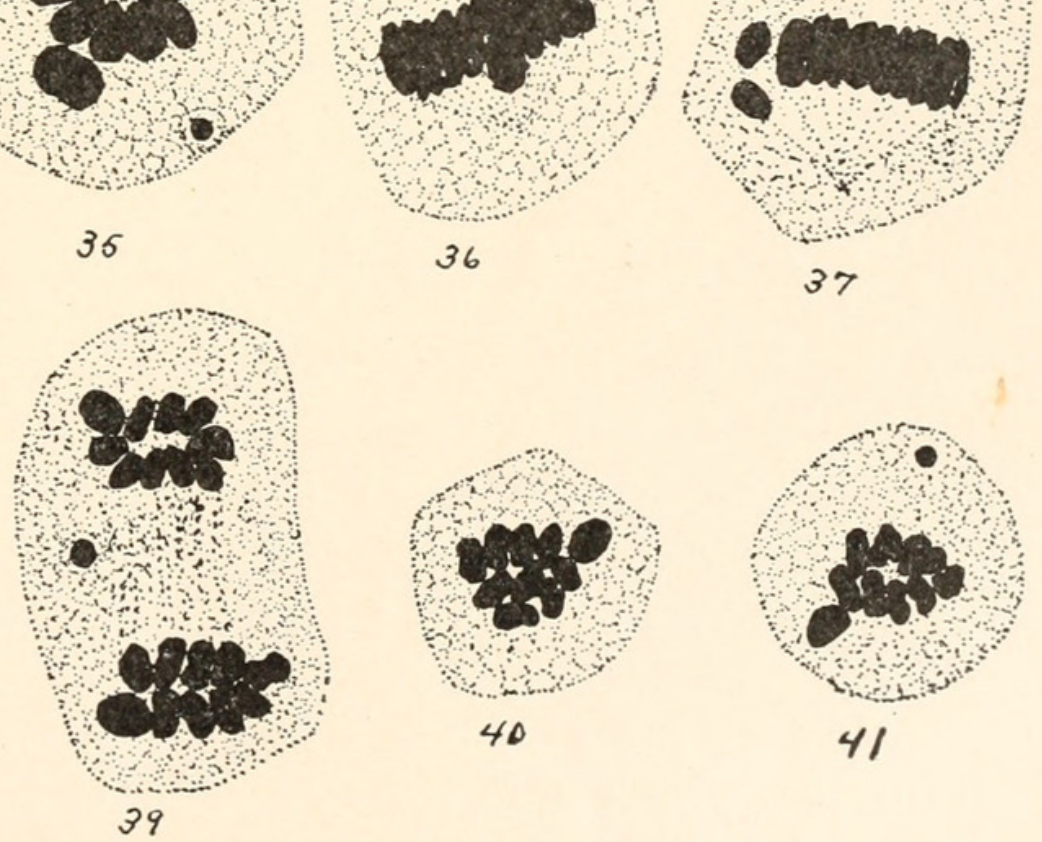

J. E WODSEDALEK. 


Plate IV,

Frgs. 42, 43, AND 44. Late prophase of division in a secondary spermatocyte which did not receive the accessory chromosome, showing only the nine ordinary chromosomes. Figs. 42 and 43 show also the chromatoid body.

Figs. 45 AND 46. Early metaphase of division in a secondary spermatocyte which did not receive the accessory chromosome. Fig. 45 shows the chromatoid body off the spindle.

Figs. 47-54. Late anaphase of division in secondary spermatocytes showing various positions of the chromatoid body when it is present. Fig. 47 shows also a small body in addition to the chromatoid body. The cell is one which did not receive the accessory chromosome. In the cell represented in Fig. 50 the chromatoid body was absent and in Fig. 54 two bodies may be seen.

FIGS. 55 AND 56. Spermatid showing nine bivalent chromosomes which is one of the resulting cells of the division of a secondary spermatocyte which did not receive the accessory chromosome. Fig. 55 shows the chromatoid body.

FIG. 57. Characteristic massing of the chromosomes just before the nuclear wall of the spermatid is formed. 

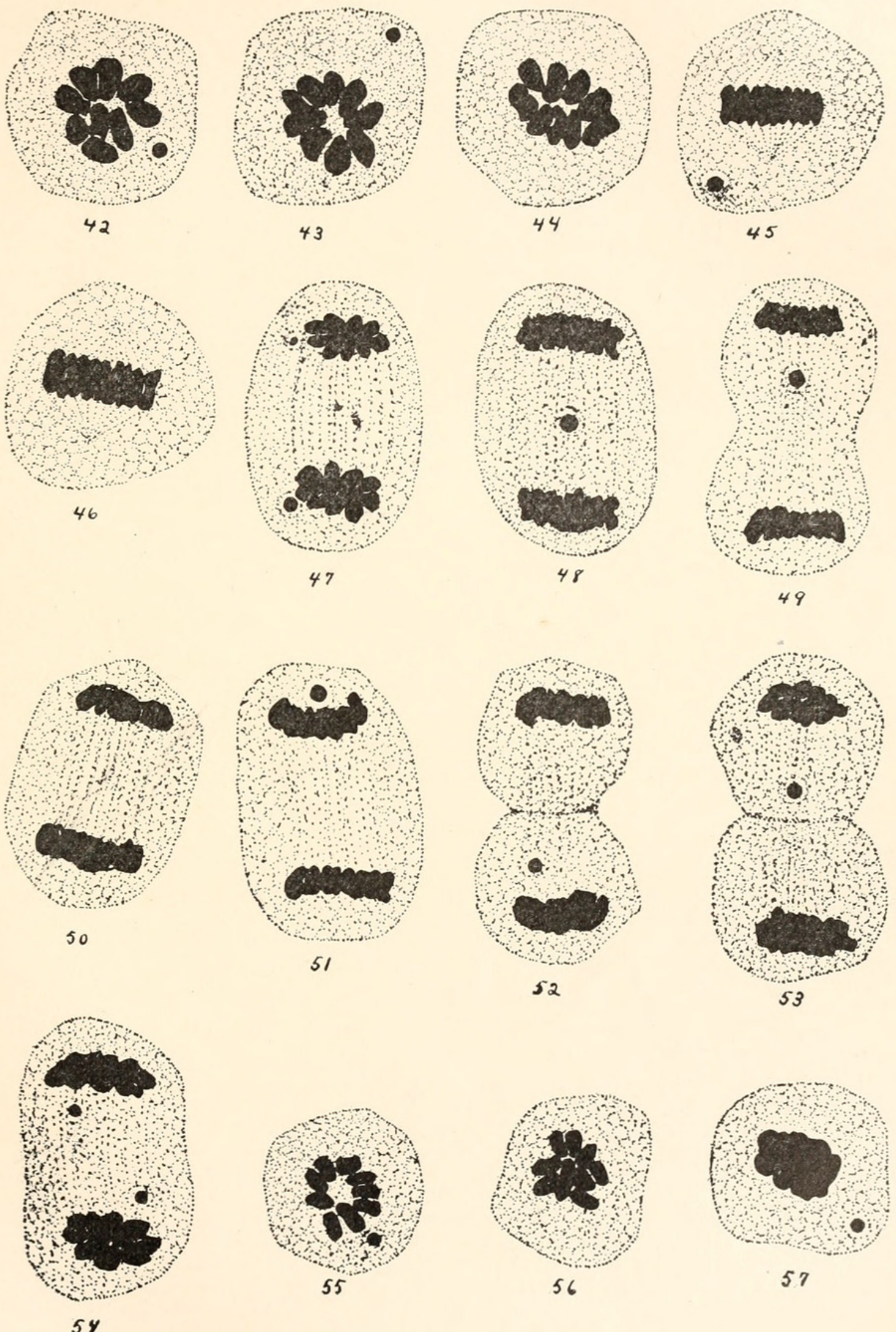

J. E. WODSEDALEK. 




\section{Plate V.}

FIGs. 58-6I. Early spermatids showing the characteristic structure of the nucleus, and the position of the chromatoid body. Fig. 60 shows two bodies of practically the same size as the chromatoid body.

FIgs. 62-67. Resting stage of the spermatid. Figs. 62-65 show the large nucleolus or the accessory chromosome. Fig. 62 shows the chromatoid body near the nucleus; Fig. 63 shows it very near the centrosome which is out of its sphere; Fig. 65 shows it at the periphery of the cell; Fig. 66 shows it near the centrosphere; and Fig. 67 shows it far from the centrosphere out of which the centrosome had just emerged.

FIGs. 68-73. Early stages of the developing spermatozoön. Fig. 68 shows the divided centrosome, the very beginning of the axial filament, and the acrosome which had migrated to the anterior end of the nucleus or sperm-head; Fig. 69 shows the posterior centrosome passing down the axial filament, and the chromatoid body far down in the cytoplasm away from the filament; Fig. 70 shows the same thing except that the chromatoid body is not present; Fig. $7 \mathrm{I}$ shows the chromatoid body near the posterior centrosome; Fig. 72 shows what apparently is the fusion of the chromatoid body with the posterior centrosome; and in Fig. 73 the chromatoid body is absent and the posterior centrosome is far down the axial filament and so small that it can scarcely be detected.

FIGS. 74 AND 75. Later stages of the developing spermatozoön showing the chromatoid body in the cytoplasm at the posterior end. Fig. 74 shows the posterior centrosome still on the filament, while Fig. 75 shows that it had been sloughed off. 

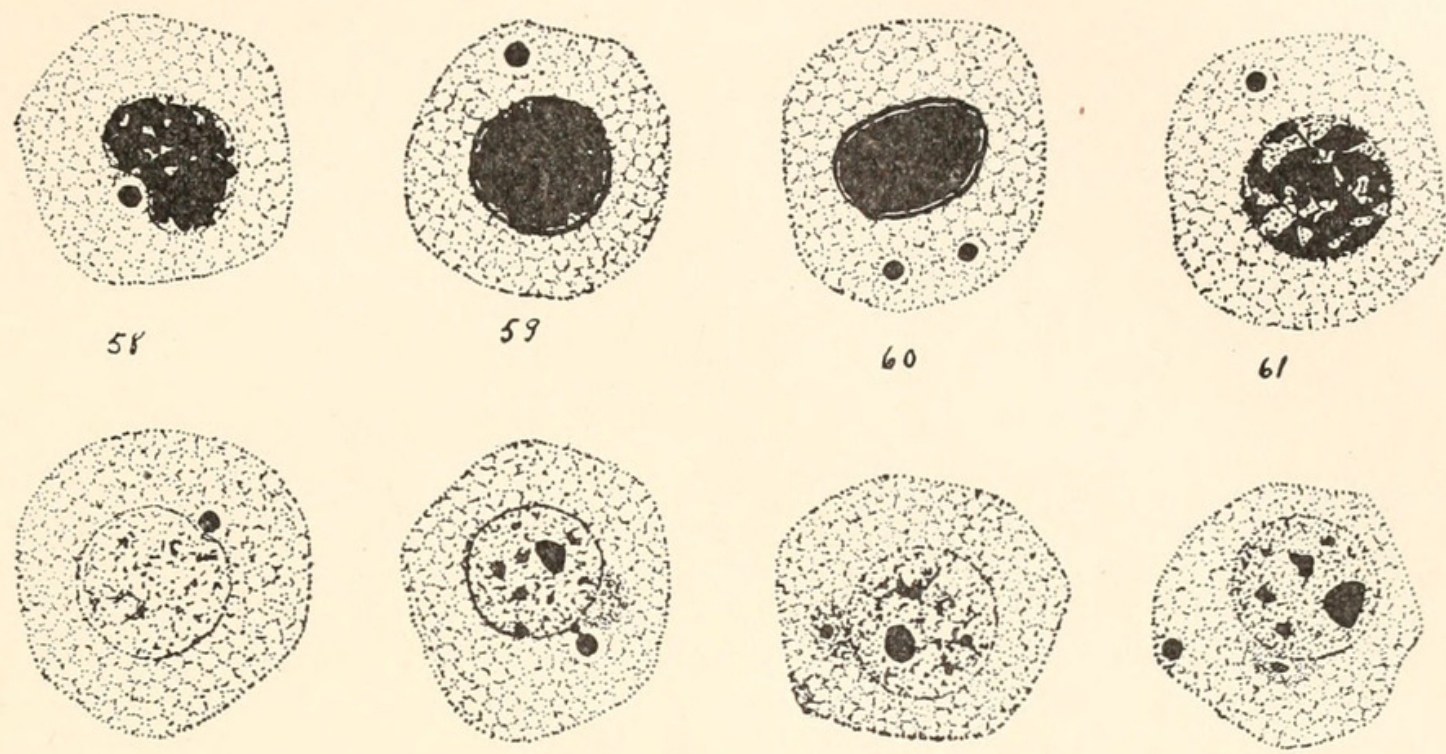

63
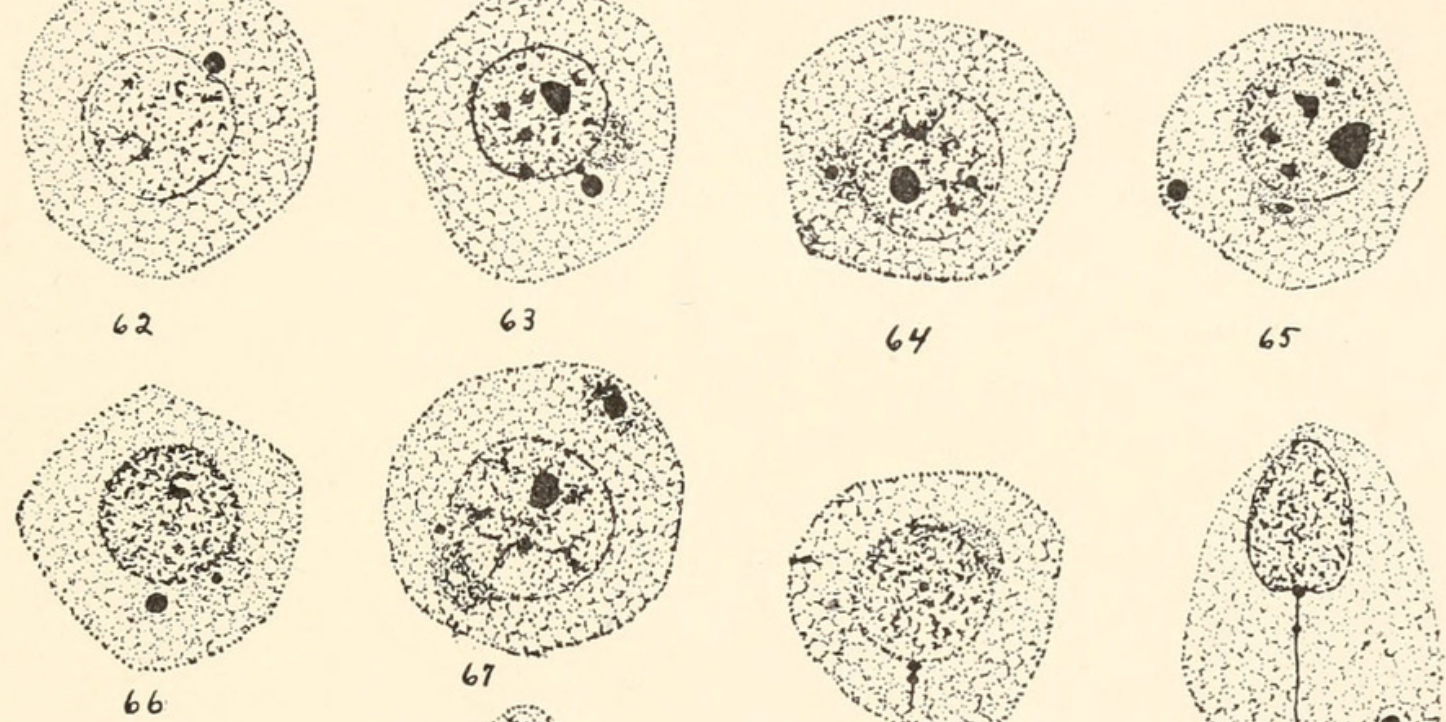

64

65
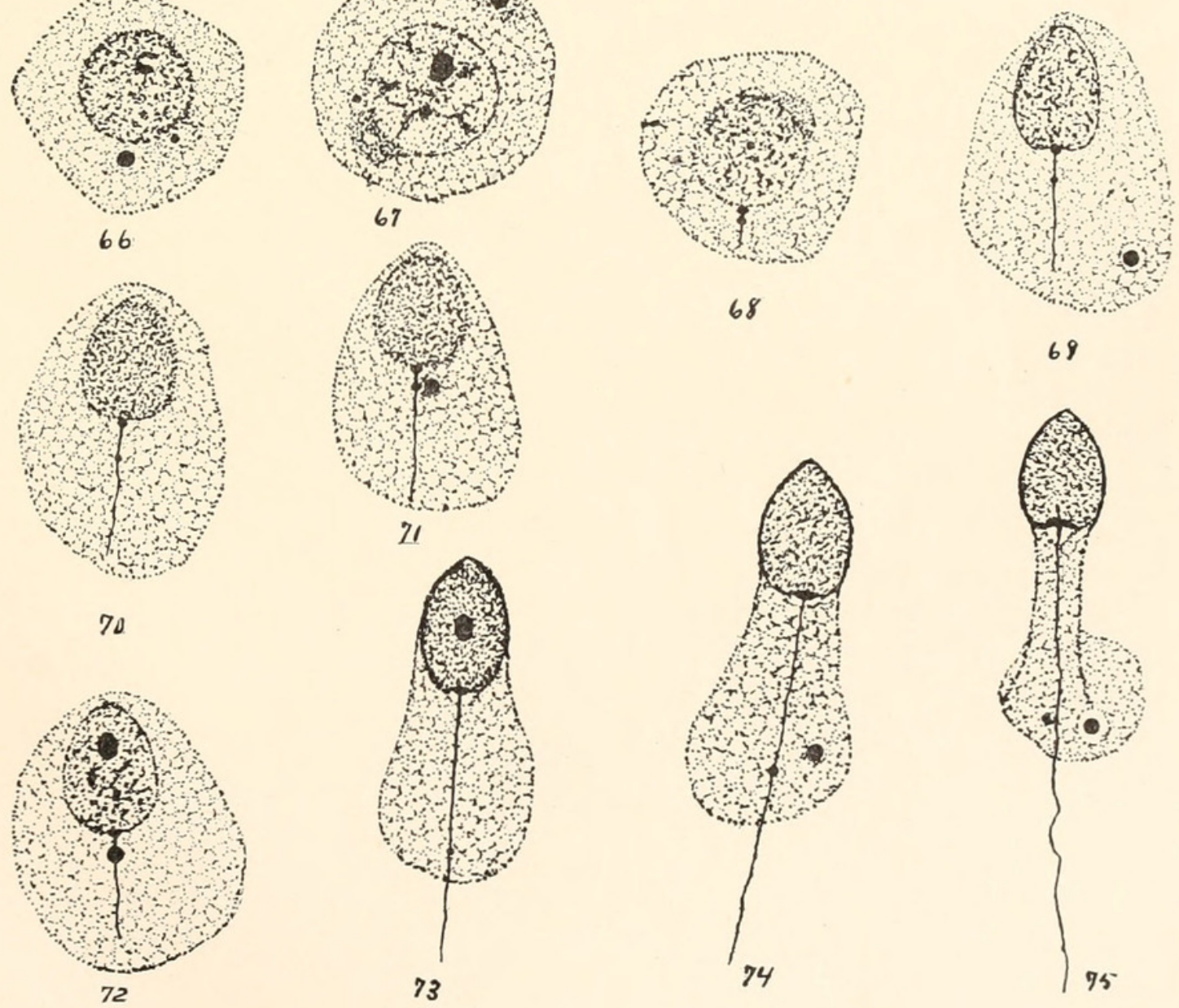

J. E. WODSEDALEK. 




\section{Plate VI.}

FIGs. 76-79. Later stages of the developing spermatozoön. Fig. 76 shows the chromatoid body far down on the axial filament; Fig. 77 shows the chromatoid body very close to the posterior centrosome; Fig. 78 shows the sloughed-off centrosome, but the chromatoid body is absent; and in Fig. 79 both of these bodies are lacking

Figs. 80-83. Cast-off balls of cytoplasm. Fig. 80 shows a small body which apparently is the sloughed-off centrosome; Fig. $8 \mathrm{I}$ shows neither the centrosome nor the chromatoid body; Fig. 82 shows both bodies; and Fig. 83 represents the ball of cytoplasm in the process of degeneration.

FIG. 84. A deeply staining body occasionally found in the lumen of the tubule and probably the same thing as the chromatoid body.

FIGS. 85 AND 86. Final stages in the developing spermatozoön. Fig. 85 shows that the cytoplasmic ball is about to be thrown off; and Fig. 86 shows the cytoplasmic mass together with the chromatoid body completely separated from the spermatozoön.

FIG. 87. Side view of a mature spermatozoön.

FIG. 88. A mature spermatozoön. 

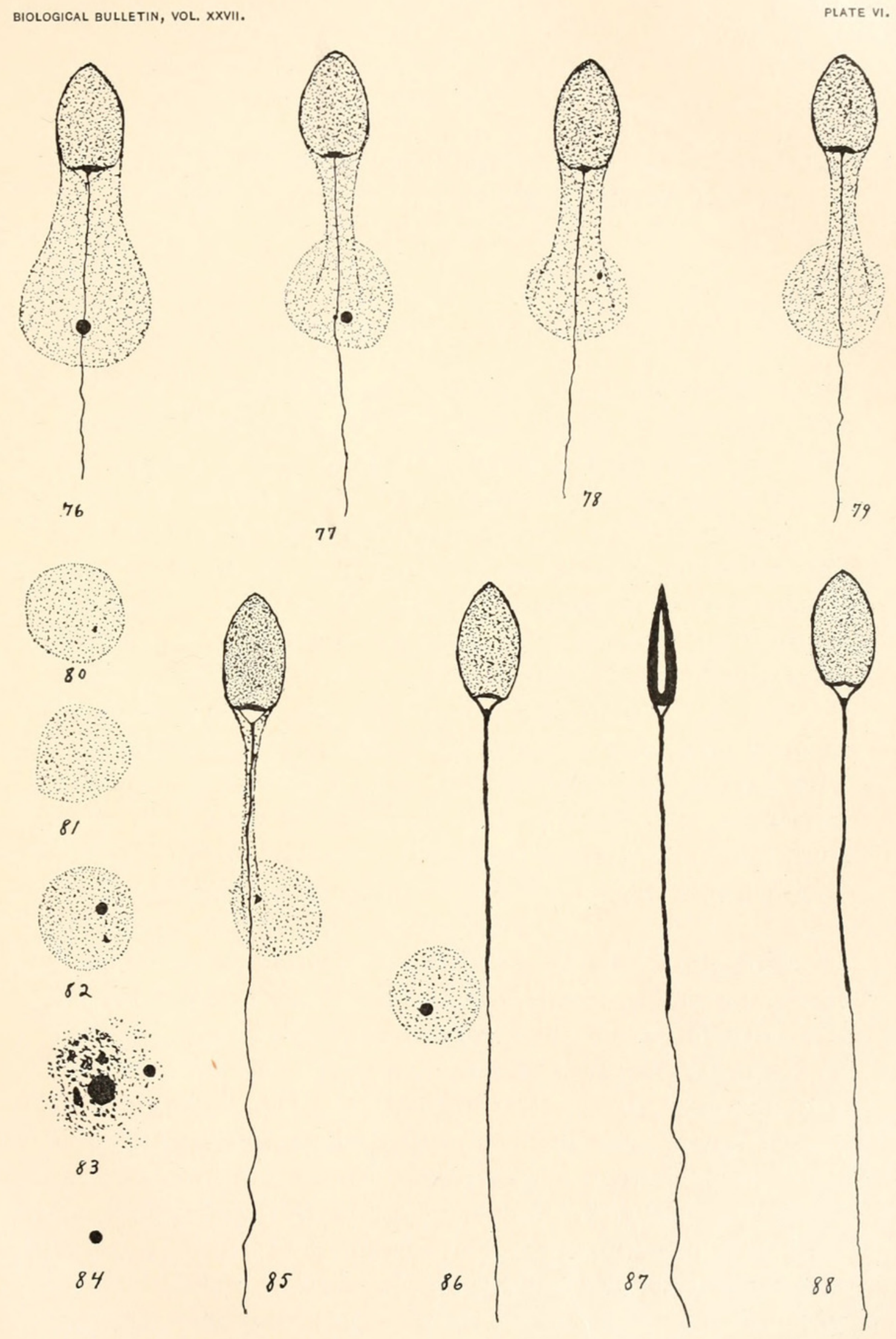

J. E. WODSEDALEK. 



\title{
AN EXPERIMENTAL STUDY OF THE AUDITORY POWERS OF THE GIANT SILKWORM MOTHS
}

(SATURNIIDÆ)

\author{
C. H. TURNER,
}

Sumner High School, St. Louis, Mo.

This is a companion paper to the "Auditory Powers of the Catocala Moths" by C. H. Turner and Ernst Schwarz. The latter paper embodies the results of a field study and this epitomizes a laboratory investigation. The habits of resting quietly upon a tree trunk and of flying, when disturbed, to a nearby tree renders the Catocalæ excellent material for field study; the fasting habits of the Saturniidæ render them equally good material for laboratory work. The paper on the Catocala moths contains both a historical resume and a bibliography; hence they are not needed in this contribution.

In these experiments the following moths were used: 79 specimens of Samia cecropia Linn., I04 of Philosamia cynthia Drury, 4I of Callosamia promethea Drury and 8I of Telea polyphemus Cramer. These insects were confined beneath wire dish covers. Each moth was numbered and one insect, in case of mated individuals one pair, was placed beneath a cover.

These experiments were conducted in an out-of-doors insectary the north wall of which is constructed almost entirely out of wire netting. The other three wooden walls are window-less and lined with shelves. These walls and the shelf-rests are supported by the ground. The wooden floor rests on the ground, but is not attached either to the walls or the shelf-rests; indeed, a space of from one to three feet separates the floor from the walls. Suspended from the ceiling by picture wire, there is a heavy swinging shelf. The subjects of these experiments were kept on these shelves. Since I always stood on the floor when sounding any of the instruments, it was impossible for the vibrations to reach the moths by any medium other than the air. 
These experiments were conducted in the mornings between five and half past seven and in the afternoons between three and seven. On Saturdays and Sundays experiments were sometimes conducted all day long.

For producing stimuli the following instruments were used: an adjustible organ pipe, with a range for all notes of two octaves and for one note of three; an adjustable pitch pipe, and an Edelmann's Galton whistle. Such moths as responded did so by moving the wings as though about to fly. In the early experiments, before I had many moths on hand, each moth was tested with all of these instruments; because I hoped to determine the upper and lower threshold of hearing for each specimen. Later on, partly because I became convinced that there are theoretical

\section{TABLE I.}

Number: 3-VI-I4: I. Specimen: Callosamia promethea, female.

Place: Confined, under a wire dish cover, on the swinging shelf.

Method: At each trial the instrument was sounded five times at intervals of a minute and records made of the moth's behavior.

\begin{tabular}{|c|c|c|c|c|c|c|c|c|c|c|c|}
\hline \multirow{2}{*}{ 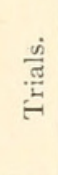 } & \multirow{2}{*}{ هّ } & \multirow{2}{*}{$\stackrel{\stackrel{E}{\Xi}}{ت}$} & \multirow{2}{*}{ 咅 } & \multirow{2}{*}{ 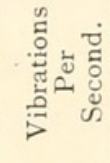 } & \multirow{2}{*}{ 节 } & \multicolumn{5}{|c|}{ Tests. } & \multirow{2}{*}{ Remarks. } \\
\hline & & & & & & I & 2 & 3 & 4 & 5 & \\
\hline I & $3-\mathrm{VI}$ & $6: 30$ & P.P. & 680 & $7 \mathrm{I}$ & $*$ & $*$ & $*$ & $*$ & $*$ & Response vigorous. \\
\hline 2 & $4-V I$ & $6: 00$ & P.P. & 680 & 78 & $*$ & $*$ & $*$ & $*$ & $*$ & Response vigorous. \\
\hline 3 & $4-V I$ & $6: 10$ & G.W. & 3,480 & 78 & 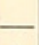 & 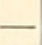 & 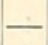 & . & & \\
\hline 4 & $4-V I$ & $6: 15$ & O.P. & 512 & 78 & $*$ & $*$ & $*$ & * & * & Response vigorous. \\
\hline 5 & $4-\mathrm{VI}$ & $6: 20$ & O.P. & 256 & 78 & $*$ & $*$ & $*$ & $*$ & * & Response slight. \\
\hline 6 & $4-\mathrm{VI}$ & $6: 25$ & O.P. & 128 & 78 & $*$ & $*$ & $*$ & * & $*$ & \\
\hline 7 & $4-\mathrm{VI}$ & $6: 30$ & O.P. & 64 & 78 & * & * & $*$ & * & $*$ & \\
\hline 8 & 6-VI & I0:05 & P.P. & 680 & 86 & - & 一 & - & - & 一 & Whistle held in rear. \\
\hline 9 & $6-V I$ & IO:IO & O.P. & 512 & 86 & - & - & 一 & - & 一 & Whistle held in rear. \\
\hline IO & $6-\mathrm{VI}$ & I0:I 5 & O.P. & 256 & 86 & — & - & — & - & — & Whistle held in rear. \\
\hline I I & $6-\mathrm{VI}$ & $10: 20$ & O.P. & 128 & 86 & - & - & — & - & - & Whistle held in rear. \\
\hline I 2 & $6-\mathrm{VI}$ & $10: 25$ & O.P. & 64 & 86 & - & - & — & - & - & Whistle held in rear. \\
\hline I3 & $6-\mathrm{VI}$ & $10: 30$ & P.P. & 680 & 86 & $*$ & _- & — & - & - & Whistle held in front. \\
\hline I4 & $6-\mathrm{VI}$ & $10: 35$ & O.P. & 256 & 86 & $*$ & * & * & * & * & Whistle held in front. \\
\hline I 5 & $6-\mathrm{VI}$ & I $5: 00$ & P.P. & 680 & 96 & $*$ & $*$ & $*$ & - & - & Whistle held in front. \\
\hline I6 & $6-\mathrm{VI}$ & $I_{5}: 10$ & O.P. & 256 & 96 & 一 & $*$ & - & * & * & Whistle held in rear. \\
\hline I 7 & 6-VI & I $5: 20$ & O.P. & 64 & 96 & & 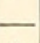 & 一 & - & - & \\
\hline I 8 & $6-\mathrm{VI}$ & I $5: 30$ & O.P. & 256 & 96 & $*$ & $*$ & $*$ & $*$ & $*$ & \\
\hline
\end{tabular}

Explanation of abbreviations; G.W. means Galton whistle; O.P., organ pipe; P.P., pitch pipe; in the second column, the roman numerals stand for months and the Arabic for days; in the third column, the hours are numbered from I to 24 , beginning at I A.M. 
reasons why the thresholds cannot be accurately determined by this method and partly on account of practical difficulties, I confined my experiments to a few notes of the middle range. When I remind you that I often had on hand from fifty to seventy-five moths, you will readily see that it was impossible to test each moth, each time, with the entire range of pitches.

The results of these investigations were recorded upon blanks that were prepared especially for this work. A portion of one of those blanks is reproduced in the preceding table.

After the work on all of the moths had been completed, the contents of these blanks were condensed into the following tables.

TABLE II.

Reactions of Giant Silk-Worm Moths to Sounds.

\begin{tabular}{|c|c|c|c|c|c|c|c|c|c|c|c|c|c|}
\hline \multirow[b]{2}{*}{ Name of the Specimen. } & \multirow{2}{*}{ 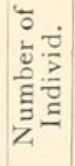 } & \multirow{2}{*}{ 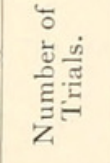 } & \multicolumn{11}{|c|}{ Per Cent. of Responses. } \\
\hline & & & $\circ$ & $\begin{array}{c}\text { I } \\
\text { to } \\
9 .\end{array}$ & $\begin{array}{l}\text { Io } \\
\text { to } \\
\text { I9. }\end{array}$ & $\begin{array}{c}20 \\
\text { to } \\
29 .\end{array}$ & $\begin{array}{c}30 \\
\text { to } \\
39 .\end{array}$ & $\begin{array}{c}40 \\
\text { to } \\
49 .\end{array}$ & $\begin{array}{c}50 \\
\text { to } \\
59 .\end{array}$ & $\begin{array}{c}60 \\
\text { to } \\
69 .\end{array}$ & $\begin{array}{c}70 \\
\text { to } \\
79 .\end{array}$ & $\begin{array}{c}80 \\
\text { to } \\
89 .\end{array}$ & $\begin{array}{c}90 \\
\text { to } \\
\text { 100. }\end{array}$ \\
\hline $\begin{array}{l}\text { Samia cecropia } \\
\text { Males. . . . . . } \ldots \ldots \ldots \ldots \ldots \\
\text { Females. } \ldots \ldots \ldots\end{array}$ & $\begin{array}{l}38 \\
4 I \\
\end{array}$ & $\begin{array}{l}380 \\
615\end{array}$ & $\begin{array}{l}\text { I } \\
\text { O }\end{array}$ & $\begin{array}{l}0 \\
0\end{array}$ & $\begin{array}{l}0 \\
0 \\
\end{array}$ & $\begin{array}{l}0 \\
\mathrm{I}\end{array}$ & $\begin{array}{l}\text { I } \\
\text { O }\end{array}$ & $\begin{array}{l}0 \\
\mathrm{I} \\
\end{array}$ & $\begin{array}{l}\text { I } \\
5 \\
\end{array}$ & $\begin{array}{l}2 \\
0\end{array}$ & $\begin{array}{l}0 \\
\text { I }\end{array}$ & $\begin{array}{l}0 \\
\mathrm{I}\end{array}$ & $\begin{array}{l}33 \\
32 \\
\end{array}$ \\
\hline 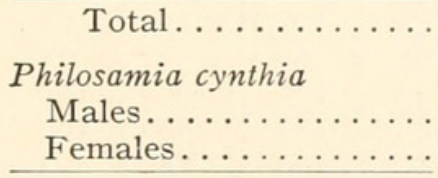 & $\begin{array}{l}50 \\
54 \\
\end{array}$ & $\begin{array}{l}950 \\
875\end{array}$ & $\begin{array}{l}\text { I9 } \\
\text { I0 } \\
\end{array}$ & $\begin{array}{l}0 \\
0 \\
\end{array}$ & $\begin{array}{l}0 \\
\mathrm{I} \\
\end{array}$ & $\begin{array}{l}2 \\
3 \\
\end{array}$ & $\begin{array}{l}4 \\
0 \\
\end{array}$ & $\begin{array}{l}4 \\
\mathrm{I} \\
\end{array}$ & $\begin{array}{r}9 \\
\text { I I } \\
\end{array}$ & $\begin{array}{l}3 \\
4 \\
\end{array}$ & $\begin{array}{l}\text { I } \\
4 \\
\end{array}$ & $\begin{array}{l}\text { I } \\
\text { I } \\
\end{array}$ & $\begin{array}{r}7 \\
19 \\
\end{array}$ \\
\hline 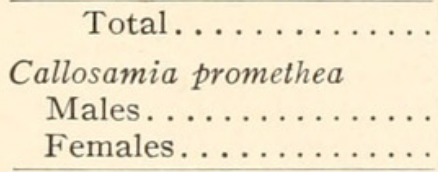 & $\begin{array}{l}23 \\
\mathrm{I} 8 \\
\end{array}$ & $\mathrm{I}, 825$ & 29 & $\begin{array}{l}0 \\
0\end{array}$ & $\begin{array}{l}0 \\
0 \\
\end{array}$ & $\begin{array}{l}0 \\
0 \\
\end{array}$ & $\begin{array}{l}3 \\
\mathrm{I} \\
\end{array}$ & $\begin{array}{l}0 \\
0\end{array}$ & 20 & $\begin{array}{l}0 \\
2\end{array}$ & $\begin{array}{l}0 \\
5 \\
\end{array}$ & $\begin{array}{l}2 \\
\text { I } \\
2\end{array}$ & $\begin{array}{r}\text { I0 } \\
6 \\
\end{array}$ \\
\hline 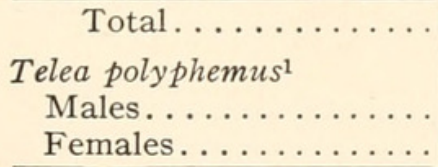 & $\begin{array}{l}39 \\
39\end{array}$ & $\begin{array}{l}950 \\
950\end{array}$ & $\begin{array}{l}36 \\
39 \\
\end{array}$ & $\begin{array}{l}0 \\
0\end{array}$ & $\begin{array}{l}0 \\
0\end{array}$ & $\begin{array}{l}\text { I } \\
0\end{array}$ & $\begin{array}{l}0 \\
0 \\
\end{array}$ & $\begin{array}{l}0 \\
0\end{array}$ & $\begin{array}{l}0 \\
0\end{array}$ & $\begin{array}{l}0 \\
0\end{array}$ & $\begin{array}{l}0 \\
0\end{array}$ & $\begin{array}{l}0 \\
0\end{array}$ & I6 \\
\hline Total............ & 78 & $I, 900$ & 75 & 0 & 0 & I & 0 & 0 & 0 & o & o & 0 & 2 \\
\hline
\end{tabular}

1 The above table does not record the three specimens of $T$. polyphemus, which were used in the special tests recorded on pages $333-334$. 
TAble III.

RESPONSES OF Samia cecropia to Sound.

\begin{tabular}{|c|c|c|c|c|c|c|c|c|c|c|}
\hline \multirow{2}{*}{$\begin{array}{l}\text { Instru- } \\
\text { ment. }\end{array}$} & \multirow{2}{*}{$\begin{array}{c}\text { Pitch } \\
\text { Vibra. } \\
\text { per } \\
\text { Second. }\end{array}$} & \multicolumn{3}{|c|}{ Individuals Participating. } & \multicolumn{3}{|c|}{ Number of Trials. } & \multicolumn{3}{|c|}{ Per Cent. of Response. } \\
\hline & & Males. & $\begin{array}{c}\mathrm{Fe}- \\
\text { males. }\end{array}$ & Total. & Males. & $\begin{array}{c}\mathrm{Fe}- \\
\text { males. }\end{array}$ & Total. & Males. & $\underset{\text { males. }}{\mathrm{Fe}}$ & Total. \\
\hline O.P. & 64 & $\mathbf{I}$ & 4 & 5 & 5 & 35 & 40 & IOO & I0o & I00 \\
\hline O.P. & I 28 & 2 & I & 3 & Io & 5 & I5 & 50 & 100 & 67 \\
\hline O.P. & 256 & 6 & 13 & 19 & 25 & 75 & 100 & IOO & 100 & 100 \\
\hline O.P. & 512 & I & 2 & 3 & 5 & I5 & 20 & IOO & 100 & 100 \\
\hline P.P. & 680 & 26 & 34 & 60 & 310 & 360 & 670 & 94 & 89 & $9 \mathrm{I}$ \\
\hline P.P. & 870 & 2 & 2 & 4 & I 5 & Io & 25 & 33 & 0 & 20 \\
\hline G.W. & 3,480 & I I & I9 & 30 & 60 & I0O & 160 & 100 & 70 & $8 I$ \\
\hline G.W. & 4,645 & 0 & I & I & 0 & 5 & 5 & & I00 & I00 \\
\hline G.W. & 6,200 & I & 0 & I & IO & o & Io & 50 & & 50 \\
\hline G.W. & 6,960 & 0 & I & I & 0 & 5 & 5 & & IOO & I00 \\
\hline G.W. & 9,290 & I & o & I & 5 & 0 & 5 & 100 & & IOO \\
\hline
\end{tabular}

Explanation of abbreviations used in above table: O.P., organ pipe; P.P., pitch pipe; G.W., Galton whistle (Edlemann's).

Table IV.

Effect of Age on the Responses of $S$. cecropia to Sound.

\begin{tabular}{|c|c|c|c|c|c|c|c|c|c|}
\hline \multirow[b]{2}{*}{ Age in Days. } & \multicolumn{3}{|c|}{ Individuals Participating. } & \multicolumn{3}{|c|}{ Number of Trials. } & \multicolumn{3}{|c|}{ Per Cent. of Responses. } \\
\hline & Males. & $\begin{array}{c}\mathrm{Fe}- \\
\text { males. }\end{array}$ & Total. & Males. & $\begin{array}{c}\mathrm{Fe}- \\
\text { males. }\end{array}$ & Total. & Males. & $\begin{array}{c}\mathrm{Fe}- \\
\text { males. }\end{array}$ & Total. \\
\hline $0-I$ & 26 & 23 & 49 & 205 & 200 & 405 & 80 & 80 & 80 \\
\hline $\mathrm{I}-2$ & 7 & I0 & I 7 & 60 & 55 & II 5 & IOO & 82 & $9 \mathrm{I}$ \\
\hline $2-3$ & 5 & II & I6 & 30 & 65 & 95 & I0o & 54 & 72 \\
\hline $3-4$ & 2 & I 2 & I 7 & Io & 120 & 130 & 100 & 100 & 100 \\
\hline $4-5$ & 4 & 4 & 8 & 20 & 25 & 45 & I0o & IOO & 100 \\
\hline $5-6$ & 2 & 3 & 5 & Io & 20 & 30 & IOO & 75 & 83 \\
\hline $6-7$ & 4 & 3 & 7 & 25 & 30 & 55 & IOO & 83 & 91 \\
\hline $7-8$ & I & 2 & 3 & I 5 & 20 & 35 & 100 & IOO & I00 \\
\hline $8-9$ & I & 2 & 3 & Io & I 5 & 25 & IOO & IOO & 100 \\
\hline 9-10 & 2 & 4 & 6 & 25 & 30 & 55 & IOO & 100 & I0o \\
\hline IO-II & 0 & 3 & 3 & 0 & I5 & I 5 & & 100 & IOO \\
\hline
\end{tabular}

Table V.

Effect of Temperature on the Responses of $S$. cecropia to Sounds.

\begin{tabular}{|c|c|c|c|c|c|c|c|c|c|}
\hline \multirow{2}{*}{ 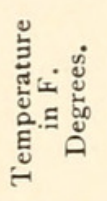 } & \multicolumn{3}{|c|}{ Individuals Participating. } & \multicolumn{3}{|c|}{ Number of Trials. } & \multicolumn{3}{|c|}{ Per Cent. of Responses. } \\
\hline & $\frac{\dot{\check{c}}}{\frac{\pi}{\pi}}$ & 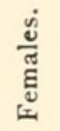 & 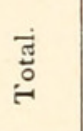 & $\frac{\dot{e j}}{\frac{\tilde{J}}{\Sigma}}$ & $\frac{\dot{j}}{\stackrel{\dot{U}}{\tilde{J}}}$ & 胥 & $\frac{\dot{\rho}}{\stackrel{\tilde{\omega}}{\tilde{z}}}$ & 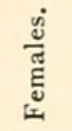 & 惡 \\
\hline $50-59$ & I I & 6 & I 7 & I30 & 70 & 200 & 83 & 53 & 70 \\
\hline $60-69$ & 9 & I4 & 23 & I30 & I IO & 240 & 74 & 87 & 80 \\
\hline $70-79$ & 4 & I6 & 20 & 40 & I 70 & 210 & 100 & 94 & 95 \\
\hline $80-89$ & I 8 & 27 & 45 & I 55 & 235 & 290 & 97 & 96 & 96 \\
\hline $90-99$ & o & 4 & 4 & o & 35 & 35 & & 100 & 100 \\
\hline
\end{tabular}




\section{Table VI.}

Effect of Mating on the Responses of $S$. cecropia to Sound.

\begin{tabular}{|c|c|c|c|}
\hline & Number of Individuals. & Number of Trials. & Per Cent. of Responses. \\
\hline $\begin{array}{l}\text { Males: } \\
\text { Unmated ..... } \\
\text { Mated ...... }\end{array}$ & $\begin{array}{r}3 \mathrm{I} \\
7\end{array}$ & $\begin{array}{l}320 \\
120\end{array}$ & $\begin{array}{l}88 \\
97\end{array}$ \\
\hline Total...... & 38 & 440 & 90 \\
\hline $\begin{array}{l}\text { Females: } \\
\text { Unmated ...... } \\
\text { Mated....... }\end{array}$ & $\begin{array}{r}36 \\
5 \\
\end{array}$ & $\begin{array}{r}520 \\
55 \\
\end{array}$ & $\begin{array}{l}86 \\
73 \\
\end{array}$ \\
\hline Total...... & $4 I$ & 575 & 85 \\
\hline Grand total..... & 79 & I,OI 5 & 88 \\
\hline
\end{tabular}

TABle VII.

Responses of Philosamia cynthia to Sound.

\begin{tabular}{|c|c|c|c|c|c|c|c|c|c|}
\hline \multirow{2}{*}{$\begin{array}{l}\text { Temperature in } \\
\text { F. Degrees. }\end{array}$} & \multicolumn{3}{|c|}{ Individuals Participating. } & \multicolumn{3}{|c|}{ Number of Trials. } & \multicolumn{3}{|c|}{ Per Cent. of Responses. } \\
\hline & Males. & $\begin{array}{c}\mathrm{Fe}- \\
\text { males. }\end{array}$ & Total. & Males. & $\begin{array}{c}\mathrm{Fe}- \\
\text { males. }\end{array}$ & Total. & Males. & $\begin{array}{c}\mathrm{Fe}- \\
\text { males. }\end{array}$ & Total. \\
\hline $60-69$ & 25 & 23 & 48 & I 45 & I 20 & 265 & $3 I$ & 42 & 33 \\
\hline $70-79$ & 43 & 43 & 86 & 410 & 420 & 830 & 36 & 60 & 48 \\
\hline $80-89$ & 23 & 34 & 57 & 245 & 300 & 545 & 33 & 67 & $5 \mathrm{I}$ \\
\hline $90-99$ & 6 & I I & I 7 & I30 & 65 & I95 & 58 & 77 & 67 \\
\hline I00-IO9 & 0 & 8 & 8 & 0 & 40 & 40 & & 88 & 88 \\
\hline
\end{tabular}

\section{TABle VIII.}

Effects of Mating on the Responses of Philosamia cynthia to Sound.

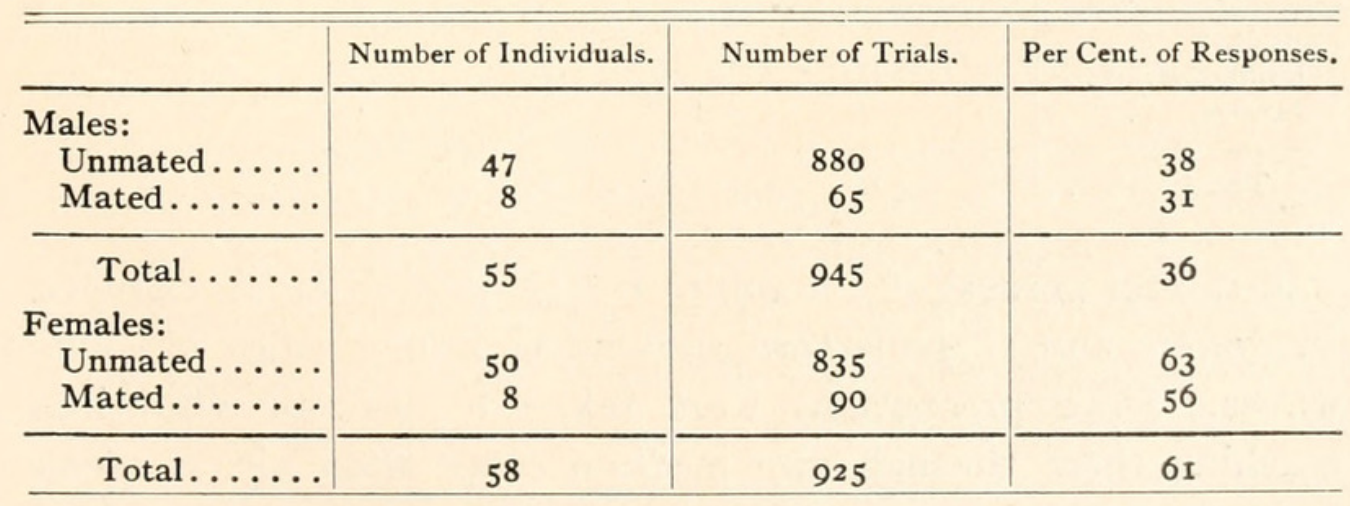


TABLE IX.

Effect of Age on the Responses of Philosamia cynthia to Sound.

\begin{tabular}{|c|c|c|c|c|c|c|c|c|c|}
\hline \multirow[b]{2}{*}{ Age in Days. } & \multicolumn{3}{|c|}{ Individuals Participating. } & \multicolumn{3}{|c|}{ Number of Trials. } & \multicolumn{3}{|c|}{ Per Cent. of Responses. } \\
\hline & Males. & $\begin{array}{c}\mathrm{Fe}- \\
\text { males. }\end{array}$ & Total. & Males. & $\begin{array}{c}\mathrm{Fe}- \\
\text { males. }\end{array}$ & Total. & Males. & $\begin{array}{c}\mathrm{Fe}- \\
\text { males. }\end{array}$ & Total. \\
\hline $0-I$ & 45 & $5 \mathrm{I}$ & 96 & 645 & 400 & $\mathrm{I}, 045$ & 34 & $5^{8}$ & 43 \\
\hline $\mathrm{I}-2$ & 26 & I9 & 45 & 290 & 160 & 450 & 49 & 68 & 57 \\
\hline $2-3$ & I 2 & I 8 & 30 & 160 & 365 & 525 & 38 & 73 & 53 \\
\hline $3-4$ & I9 & I9 & 38 & I 45 & 105 & 250 & 32 & 58 & 42 \\
\hline $4-5$ & 6 & I 2 & I 8 & 45 & 70 & I I 5 & 32 & 64 & 48 \\
\hline $5^{-6}$ & I & 6 & 7 & 5 & 30 & 35 & IOO & 83 & 85 \\
\hline $6-7$ & I & I & 2 & 5 & 5 & Io & o & I00 & 50 \\
\hline $7-8$ & 2 & 4 & 6 & Io & 20 & 30 & o & 501 & 34 \\
\hline 9-Io & 0 & 2 & 2 & o & Io & IO & o & 50 & 50 \\
\hline
\end{tabular}

TABle X.

Effect of Temperature on the Responses of Callosamia promethea to Sound.

\begin{tabular}{|c|c|c|c|c|c|c|c|c|c|}
\hline \multirow{2}{*}{$\begin{array}{l}\text { Temperature in } \\
\text { F. Degrees. }\end{array}$} & \multicolumn{3}{|c|}{ Individuals Participating. } & \multicolumn{3}{|c|}{ Number of Trials. } & \multicolumn{3}{|c|}{ Per Cent. of Responses. } \\
\hline & Males. & $\begin{array}{c}\text { Fe- } \\
\text { males. }\end{array}$ & Total. & Males. & $\begin{array}{c}\mathrm{Fe}- \\
\text { males. }\end{array}$ & Total. & Males. & $\begin{array}{l}\mathrm{Fe}- \\
\text { males. }\end{array}$ & Total. \\
\hline $50-59$ & I & o & I & 5 & o & 5 & 100 & & I00 \\
\hline $60-69$ & 7 & 3 & IO & 50 & 20 & 70 & 70 & 75 & $7 \mathrm{I}$ \\
\hline $70-79$ & Io & I3 & 23 & I25 & 125 & 250 & 72 & 80 & 76 \\
\hline $80-89$ & I6 & I 8 & 34 & I35 & 250 & 385 & 56 & 76 & 69 \\
\hline $90-99$ & IO & I 8 & 28 & 70 & I 50 & 220 & $7 \mathrm{I}$ & 87 & 82 \\
\hline I00-I09 & 0 & 8 & 8 & o & 40 & 40 & & 63 & 63 \\
\hline
\end{tabular}

TABLE XI.

Effect of Mating on the Responses of Callosamia promethea to Sound.

\begin{tabular}{|c|c|c|c|}
\hline & Number of Individuals. & Number of Trials. & Per Cent. of Responses. \\
\hline $\begin{array}{l}\text { Males: } \\
\text { Unmated ...... } \\
\text { Mated ....... }\end{array}$ & $\begin{array}{r}\text { I9 } \\
3\end{array}$ & $\begin{array}{r}375 \\
55\end{array}$ & $\begin{array}{l}63 \\
82\end{array}$ \\
\hline $\begin{array}{l}\text { Total...... } \\
\text { Females: } \\
\text { Unmated..... } \\
\text { Mated...... }\end{array}$ & $\begin{array}{l}2 \mathrm{I} \\
\text { I5 } \\
3\end{array}$ & $\begin{array}{r}430 \\
515 \\
62\end{array}$ & $\begin{array}{l}80 \\
80\end{array}$ \\
\hline Total....... & I 8 & 575 & 80 \\
\hline
\end{tabular}

A careful perusal of the tables I-XII. shows that S. cecropia, $P$. cynthia and $C$. promethea, respond to a long range of sound waves. Since precautions were taken to prevent vibrations reaching them through any medium other than air, it seems 
TABLE XII.

EFfect of Age on the Responses of Callosamia promethea to Sound.

\begin{tabular}{|c|c|c|c|c|c|c|c|c|c|}
\hline \multirow{2}{*}{ Age in Days. } & \multicolumn{3}{|c|}{ Individuals Participating. } & \multicolumn{3}{|c|}{ Number of Trials. } & \multicolumn{3}{|c|}{ Per Cent. of Responses } \\
\hline & Males. & $\begin{array}{c}\mathrm{Fe}- \\
\text { males. }\end{array}$ & Total & Males. & $\begin{array}{c}\mathrm{Fe}- \\
\text { males. }\end{array}$ & Total. & Males. & $\begin{array}{c}\text { Fe- } \\
\text { males. }\end{array}$ & Total. \\
\hline $0-I$ & I 7 & I3 & 30 & I 55 & I05 & 260 & 74 & 76 & 75 \\
\hline $\mathrm{I}-\mathrm{O}$ & I 4 & I4 & 28 & I 25 & I 35 & 260 & 68 & 89 & 79 \\
\hline $2-3$ & I I & I3 & 24 & 60 & I 25 & I 85 & 50 & 92 & 78 \\
\hline $3-4$ & 7 & IO & I 7 & 35 & 75 & IIO & 30 & 75 & 58 \\
\hline $4-5$ & 2 & 8 & IO & IO & I05 & I I 5 & IOO & 57 & $6 I$ \\
\hline $5-6$ & I & 6 & 7 & 5 & 45 & 50 & o & 56 & 50 \\
\hline $6-7$ & o & I & I & o & 5 & 5 & & IOO & IOO \\
\hline $7-8$ & 0 & I & I & o & 5 & 5 & & IOO & IOO \\
\hline
\end{tabular}

reasonable to conclude that they hear. How about Telea polyphemus? Of the seventy-eight individuals whose behavior is recorded in Table II. only three made any responses whatever. Of these three, two gave over ninety per cent. of responses and the other less than thirty. Shall we conclude that Telea polyphemus is deaf and that these few responses were due to some factor overlooked by the investigator; or, shall we consider the responses made by all of these moths as expressions of emotion, and attribute the non-responsiveness of polyphemus to a sluggish temperament?

To one who has worked much with Telea polyphemus, this last suggestion is fascinating; for this moth is exceptionally unresponsive to all ordinary stimuli. The opposite sex is about the only thing that arouses much activity. There is another possibility. Telea polyphemus is not a very conspicuous object; indeed, in certain situations, it might be considered protectively colored. It may be that correlated with this inconspicuous coloration is an instinct to remain rigidly immobile in the presence of all ordinary stimuli. To test the matter the following experiments were conducted.

A freshly emerged Telea polyphemus, the wings of which had become thoroughly dry, was tested with an organ pipe set to produce 256 vibrations per second. As was to be expected, there was no visible response. The organ pipe was then sounded five times in rapid succession. Immediately thereafter, the insect was roughly handled for a few minutes. It was tossed 
about, gently squeezed and thrown upon its back. This was repeated over and over again, sometimes in one order and sometimes in another. After the moth had quieted down, the pipe was sounded five times in rapid succession. Each time the pipe was sounded, the moth waved its wings vigorously. At intervals of two hours, this experiment was repeated from early morning until dark. Invariably the moth responded in the same manner. On the following day the experiment was continued with the same moth. The result was always the same.

About a week later, similar experiments were conducted with two other specimens of the same moth. These, like the one used above, were females. With two exceptions, the results were identical. The exceptions were as follows: (I) one of the moths instead of moving its wings vigorously moved them slowly; the other two moths moved their wings so vigorously that they were lifted off of the support; in this case the body remained on the support, although the wings moved each time the whistle blew; (2) on two occasions a moth that had been experimented upon several times, instead of waiting for the five tones that were produced after the handling, waved its wings vigorously to each of the five preliminary notes. Evidently Telea polyphemus can hear. These experiments induced in those moths a state of nervous excitability which caused them to respond to the sounds produced.

\section{Conclusions.}

I. It seems certain that all four of the species of giant silkworm moths investigated can hear. Three of the species respond readily to a large range of sounds. The third, Telea polyphemus, normally does not respond to sounds; unless remaining as immobile as possible be considered a response. By experimentally causing the moth to associate some disagreeable experience with certain sounds, it can be induced to respond to those sounds.

2. There is much evidence that the responses of moths to stimuli are expressions of emotion. The fact that an insect does not respond to a sound is no sign that it does not hear it. The response depends upcn whether or no the sound has a life, significance. 


\title{
A PRELIMINARY ACCOUNT OF SOME CYTOLOGICAL CHANGES ACCOMPANYING DESICCATION.
}

\author{
LOUIS M. HICKERNELL,
}

Princeton University.

The ability of certain rotifers, tardigrades and nematode worms to withstand periods of desiccation has been a subject of investigation for many biologists throughout a period of more than two hundred years. Beginning with von Leeuwenhoek in I 70 I and extending to the present time, researches have been carried on at intervals, in the case of the Bdelloid rotifers, with the object of determining whether or not these animals can undergo a true desiccation. The results of the several authors have shown a striking variance, in fact in some cases the conclusions of one worker have been directly opposed to those of some other who used the same species of animal in his experiments. The latest publication upon this subject is that of Jacobs ('og) who worked on the Bdelloid rotifer, Philodina roseola. He concludes, after prolonged experimentation and as a result of chemical and physical tests as well as by other indirect methods, that this animal undergoes a true desiccation; that at all times the cuticle is freely permeable to water and gases and that no evidence of a waterproof cyst can be found. He notes further that desiccation is usually followed by a period of reproductive activity. The foregoing conclusions together with others not bearing directly upon the subject of this paper have been confirmed during the course of this study.

Jacobs, while conducting his investigation in a very thorough manner, made no attempt to determine, from a histological or cytological point of view, the condition of the tissues of the desiccated animals as compared with those in the normal individual. To the knowledge of the author no comparison of this sort has been attempted by any investigator up to the present time. At the suggestion of Dr. E. G. Conklin, I have undertaken an inquiry into this last question and present here a brief account 
of the results obtained to date. A more detailed account based upon further work will appear in a future publication.

The anatomy of the Philodinidæ has been described by Janson (I 893). The most conspicuous organs in the living animal are those of the reproductive and the alimentary systems. The latter begins with the buccal cavity at the base of the trochal organs. This narrows down to a short tube leading to the mastax. The mastax, with the digestive glands surrounding it, is followed by the thin-walled esophagus which leads into the thick-walled stomach. The posterior end of the latter is continued by the "blasendarm" which leads to the cloaca and thence to the anus. The reproductive organs consist of two more or less spindle-shaped bodies lying on either side of the stomach. These are the ovaries and the vitellaria and they may at all times be recognized by their prominent nuclei. The nephridia with their flame cells are easily observed in the living animal. In the foot are found the glands which secrete a substance which enables the animal to adhere to different objects. The head region contains several large coronal cells with large nuclei.

A cross section of a normal extended $P$. roseola through the mid-body region is shown in Fig. I. The vitellaria have enormous nuclei, consisting of a central karyosome surrounded by a clear homogeneous area and peripherally by a distinct nuclear membrane. This is the "nucleolar nucleus" of Carnoy and this type of nucleus is characteristic of the greater part of the cells of the animal. The cytoplasm of the vitellarium, which is syncytial in nature, is made up of granules of varying sizes and these granules appear in different patterns particularly when a variety of fixatives are used; it has quite an affinity for nuclear stains as is usual with yolk structures. The cytoplasm of the ovary does not differ essentially from that of the vitellarium. Ovary and vitellarium are each surrounded by a thin membrane. Figs. I and 4 show characteristic sections through normal reproductive glands.

The cytological structure of the stomach of the Philodinidæ has been described by Zelinka ('86) in the case of Callidina symbiotica, by Janson ('93), and more recently by de Beauchamp ('o9), in the case of Callidina socialis. The lumen, the position 
of which in the stomach tissue is not constant, is lined with a heavy ciliated cuticula. Just beneath the cuticula are found longitudinal muscle fibers arranged at regular intervals. The part of the stomach outside the thin layer of muscle fibers is syncitial in nature. With the iron-hæmatoxylin-eosin-lichtgrün stain of de Beauchamp three elements may be distinguished, (I) nuclei having, in general, the same structure as those described for the vitellarium; (2) densely staining granules of great size, not surrounded by a clear area or membrane. These are probably aggregations of food material. (3) Vacuoles of greater or less size which stain with lichtgrün. These last are probably globules of excretory material as de Beauchamp has pointed out. In the latter's description of the stomach of Callidina socialis he says that the stomach is not surrounded by an "individualized membrane" but only by a layer of protoplasm which projects at the periphery. In P. roseola, as far as I have been able to determine, a true membrane is present (Fig. I).

The skin of $P$. roseola has practically the same structure as that of other rotifers. It consists of two layers, cuticula and hypodermis. The former is the more densely staining layer and is composed of fine granules closely packed together; the latter is a finely reticulated plasma layer in which cell boundaries cannot be distinguished and in which nuclei are found scattered at irregular intervals. The skin is pliable and may be readily folded at any point. It is difficult to obtain sections in which one or more of these folds do not appear.

The brain of $P$. roseola is of an elongated triangular shape and lies in front of and slightly above the mastax. Zelinka ('88), in the case of Discopus synapte, has figured the brain as a syncitium in which the nuclei are closely packed together about the periphery, while in the central part is found the "punkstubstanz," a finely granular portion without nuclei. In the greater number of cases I have been able to distinguish definite cell boundaries in the case of the cells forming the peripheral layer of the brain of $P$. roseola. The nuclei of these cells are uniformly circular in section and contain a small amount of chromatin scattered in irregular masses through a homogeneous nuclear plasm. The cytoplasm is homogeneous and has the appearance of a colorless 
fluid. The "punktsubstanz" lies approximately at the center of the organ and is granular in structure.

In the fully extended living Philodina the ciliated or trochal discs are prominent at the anterior end of the body. The cilia upon these discs by their successive beating give the effect of a revolving wheel. When the animal is disturbed the discs are folded and retracted into the pharyngeal region where they may be observed as oval patches. The alimentary canal is also ciliated throughout almost its entire length.

Of the glandular structures, other than those employed for reproduction, the slime glands of the foot are perhaps most easily seen. These consist of rows of cells whose cytoplasm is alveolar or finely reticular. The nuclei are large and may sometimes be seen in the living animal. The digestive glands in the region of the mastax are similar to the foot glands in structure and staining qualities.

The changes in cell organization which accompany the process of desiccation are fairly uniform in result for all the tissues. Although slight variations have been observed, these are differences of degree and not of kind. Since the cellular elements are larger and hence more easy to observe in the vitellarium, this organ will be considered first.

In a section of the vitellarium of a desiccated $P$. roseola the most noticeable difference from the conditions which are present in the normal tissues are seen in the nucleus. Normally, as was stated before, the nuclear membrane, though definite, is not very thick. Just within the membrane is a ring of homogeneous ground substance or nuclear sap. In the center of the nucleus is found the large, densely staining karyosome. In the dried animal these conditions are exactly reversed. The karyosome may disappear entirely but if this extreme condition does not come about, the structure which remains in the position of the karyosome is similar neither in shape nor in staining qualities to the original element. In extreme cases the central area of the nucleus in the dried organ has exactly the same appearance as the clear area of the normal nucleus. The nuclear membrane becomes heavy and has the appearance of a thick ring (Fig. 5). In most cases it appears to be composed of fine granules closely 
packed together. Under conditions mentioned hereafter this granular appearance may give place to a dense homogeneous black ring (iron-hæmatoxylin preparations) staining exactly like the normal karyosome. The changes in the cytoplasm, though distinct, are much less marked than the nuclear changes. With the withdrawal of water the cytoplasm increases in density and loses the regular arrangement of its particles which is characteristic of the normal vitellarium (Fig. 4). The yolk granules become arranged irregularly or in small closely packed groups as in Fig. 5. The drying process causes a loss of staining power in the tissue.

The shrinkage of the cytoplasmic portion of the tissues is well demonstrated in the case of the hypodermis. Fig. I show as section of this layer of the skin as it appears in the animal living under normal conditions. In a section through the dried animal (Fig. 2) it will be noticed that the hypodermal layer has shrunken markedly, approaching its normal thickness only in those places where the nuclei are located. The nuclei apparently do not diminish in size and they cause a protuberance in the dried hypodermis wherever they are found. The nuclear material is redistributed in the same manner as was described for the vitellarium.

This arrangement of the nuclear elements is found in practically all the tissues of the dried animals. A detailed description of the changes in the other organs would be, for the most part, mere repetition.

As was mentioned above, the cilia in $P$. roseola are well developed, both in the head region and in the digestive tract. It would seem that a fiber of such delicate texture as that of a cilium would not long survive the effects of a removal of moisture. Such, however, is not the case. Not only do the trochal cilia escape serious injury by the desiccation process but the same is also true of those in the digestive canal. Fig. 2 shows a section cut through the infolded trochal discs of a dried animal. There is no sign of any fusion or other abnormal condition of these elements. Each cilium preserves its identity apparently as well as would those of an animal living in a natural environment.

The changes in cell structure attending recovery from desicca- 
tion are almost the exact opposite of those just described. In cases where the karyosome has entirely disappeared it begins to form again in its proper position a short time after water is added to the dried animals. The thickened nuclear membrane described above shows a greater affinity for stains at this stage and gradually assumes its normal thickness. Cytoplasmic changes are quite noticeable at this time. In the vitellarium (Fig. 6) it is frequently noticed that the material surrounding the nucleus is aggregated into strands or other irregular patterns. This would seem to indicate that the cytoplasm is more freely permeable to water in certain regions than in others and that the stage represented in Fig. 7 shows a step in the gradual redistribution of extranuclear substance attending recovery from desiccation. In the case of the other organs, as before, the process of recovery is very similar. The elements are much smaller in some cases and hence more difficult to observe but the mechanism as well as the result seems to be the same.

It has been suggested to the author that the cytoplasmic and the nuclear changes taking place in dry seeds might be analogous to the ones in the rotifers just described. With this in mind, sections of the embryo of the common Indian corn, Zea mais, were cut, (I) at the time the seeds were fully ripened but had not become entirely dried; (2) after the seeds were thoroughly dried; and (3) after the seeds were well germinated. A section of a typical procambium cell from each of these stages is shown herewith. Fig. I4 shows a cell from a germinating embryo. It will be noticed that the cytoplasm contains many spaces filled with cell sap. The nucleus has a ring of chromatic material just within the nuclear membrane. The nucleolus is vacuolated and does not stain in the same manner as the chromatic ring at the periphery of the nucleus. The nucleolus is surrounded by a clear area which probably consists of fluid material. Fig. I5 shows the conditions which exist when the embryo is partially dried. The chromatic ring thickens, diminishing the space between it and the nucleolus. The latter becomes more compact and the vacuoles disappear. An extreme case of drying is shown in Fig. I6. The cytoplasmic granules are closely and regularly packed together. The clear space in the nucleus has disappeared 
and the substance of the nucleolus has apparently diffused throughout the nuclear area.

The changes described for the drying corn cells in the last paragraph are at first sight remarkably like those occurring in the rotifer during desiccation. In both rotifer and corn the nucleus contains a nucleolus surrounded by a clear space, while around the two is a chromatic membrane of varying thickness. When water is removed the clear space around the nucleolus disappears and comes into existence again only upon the addition of water. The substance of the nucleolus in both cases diffuses toward the periphery of the nucleus leaving a more or less clear space in the center of the same. In the cytoplasm also there is a parallel between the behavior of the cells of the two forms. Loss of water is attended by shrinkage and a consequent increase in density. The cytoplasmic materials tend to gather in small lumps which remain closely packed together until moisture is again applied.

Whether the seemingly similar processes in these representatives of the plant and animal kingdom are indeed analogous can be determined only after further study.

de Beauchamp, P. M.

\section{LITERATURE CITED.}

'o9 Recherches sur les Rotiféres: les formations tegumentaires et l'appareil digestif. Arch. Zool. Exp., Paris, Ser. 4, Vol. Io.

Jacobs, M. H.

'og The Effects of Desiccation on the Rotifer Philodina roseola. Jour. Exp. Zool., Vol. 6.

Janson, F. O. F.

'93 Versuch einer Uebersicht über die Rotatorien-Familie der Philodinaeen. Abh. der Nat. Ver. zu Bremen, Band XII.

Zelinka, C.

'86 Studien über Raderthiere. Ueber die Symbiose und Anatomie von Rotatoria aus dem Genus Callidina. Zeit. Wiss. Zool, Band. 44. 
Description of Plate I.

FIG. I. Cross section through the mid-body region of a normal expanded Philodina roseola. Leitz compensating ocular 4 , obj. $2 \mathrm{~mm}$.

Fig. 2. Section of a rotifer kept for eighteen days previous to fixation in an evacuated calcium chloride desiccator. Leitz oc. 4 , obj. $2 \mathrm{~mm}$.

FIG. 3. Section through a normal animal, not expanded. Leitz oc. 4, obj. $2 \mathrm{~mm}$.

FIG. 4. Section through the vitellarium of a normal animal. Leitz oc. I2, obj. $2 \mathrm{~mm}$.

FIG. 5. Section of the vitellarium of an animal dried in an evacuated desiccator for fourteen days previous to fixation. Leitz oc. 8 , obj. $2 \mathrm{~mm}$.

FIG. 6. Longitudinal section of an animal recovering from desiccation. The rotifer was kept in an evacuated desiccator for fifteen days, then placed in water for an hour and fifteen minutes, at the end of which time it was fixed. Leitz oc. 8, obj. $2 \mathrm{~mm}$.

FIG. 7. Cross section of vitellarium of animal recovering from desiccation. Animal was kept in an evacuated desiccator for six days, then placed in water for one hour, at the end of which time it was fixed. Leitz oc. 8 , obj. $2 \mathrm{~mm}$. 

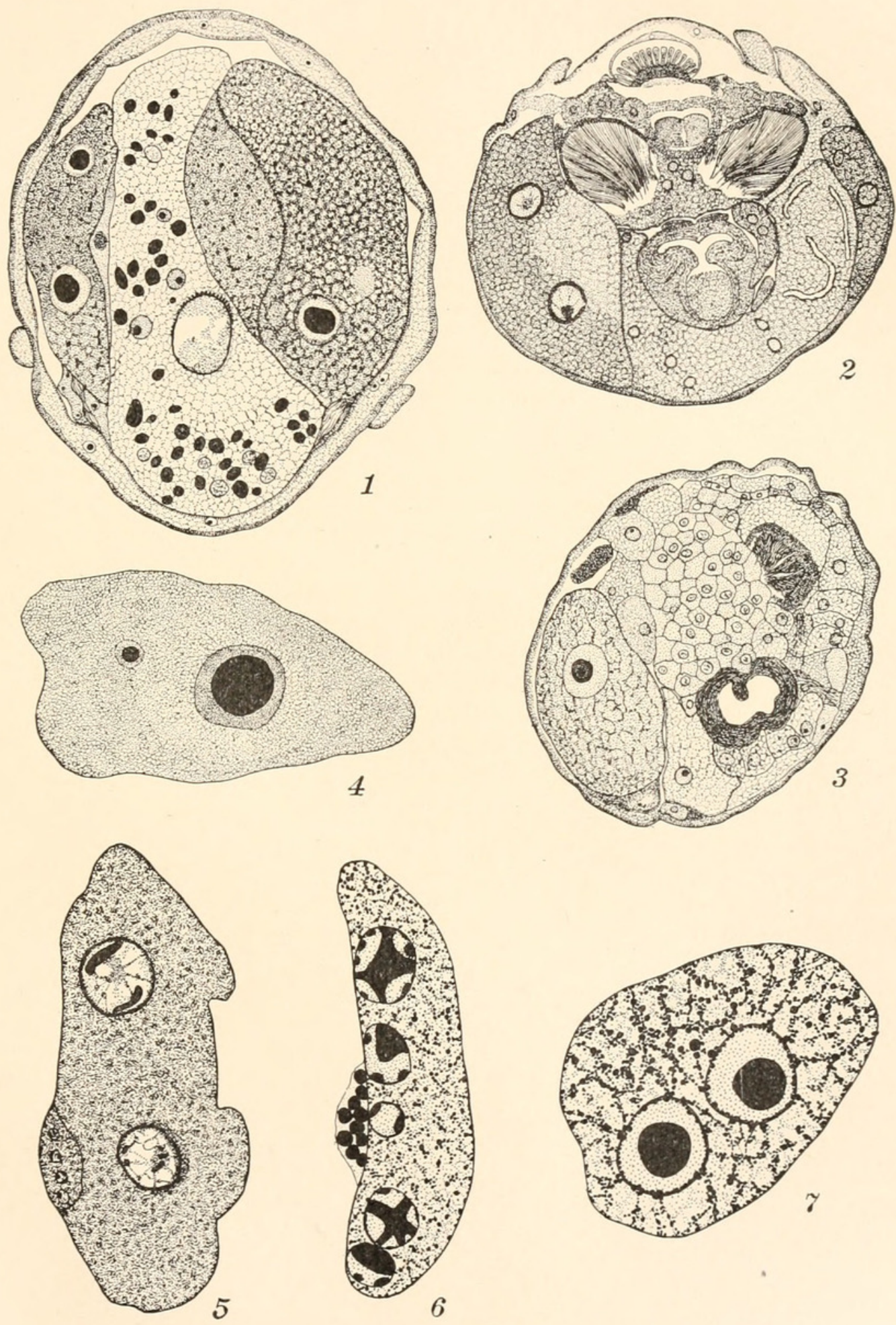

LOUIS M. HICKERNELL. 


Plate II.

FIG. 8. Section of brain of $P$. roseola. Normal active animal. Leitz oc. 8, obj. $2 \mathrm{~mm}$.

FIG. 9. Section of brain of a rotifer which was kept in an evacuated desiccator for fourteen days previous to the time of fixation. Leitz oc. 8, obj. $2 \mathrm{~mm}$.

FIG. I0. Section of brain of a rotifer which was dried twenty-four hours, put in water for one hour and then killed. Leitz oc. 8 , obj. $2 \mathrm{~mm}$.

FIG. II. Section of foot gland cells from a normal active animal. Leitz oc. I2, obj. $2 \mathrm{~mm}$.

FIG. I2. Section of foot gland ells of a rotifer which was kept in an evacuated desiccator for fourteen days previous to the time of fixation. Leitz oc. I2, obj. $2 \mathrm{~mm}$.

FIG. I3. Section of foot gland cells from an animal kept fourteen days in an evacuated desiccator and then placed in water for one and one fourth hours previous to fixation. Leitz oc. I2, obj. $2 \mathrm{~mm}$.

FIG. I4. Section of procambium cell from a germinating corn embryo. Leitz oc. 8 , obj. $2 \mathrm{~mm}$.

FIG. I5. Section of procambium cell from a partially dried corn embryo. Leitz oc. 8 , obj. $2 \mathrm{~mm}$.

FIG. 16. Section of procambium cell from a corn embryo dried for a month at room temperature. Leitz oc. 8 , obj. $2 \mathrm{~mm}$. 

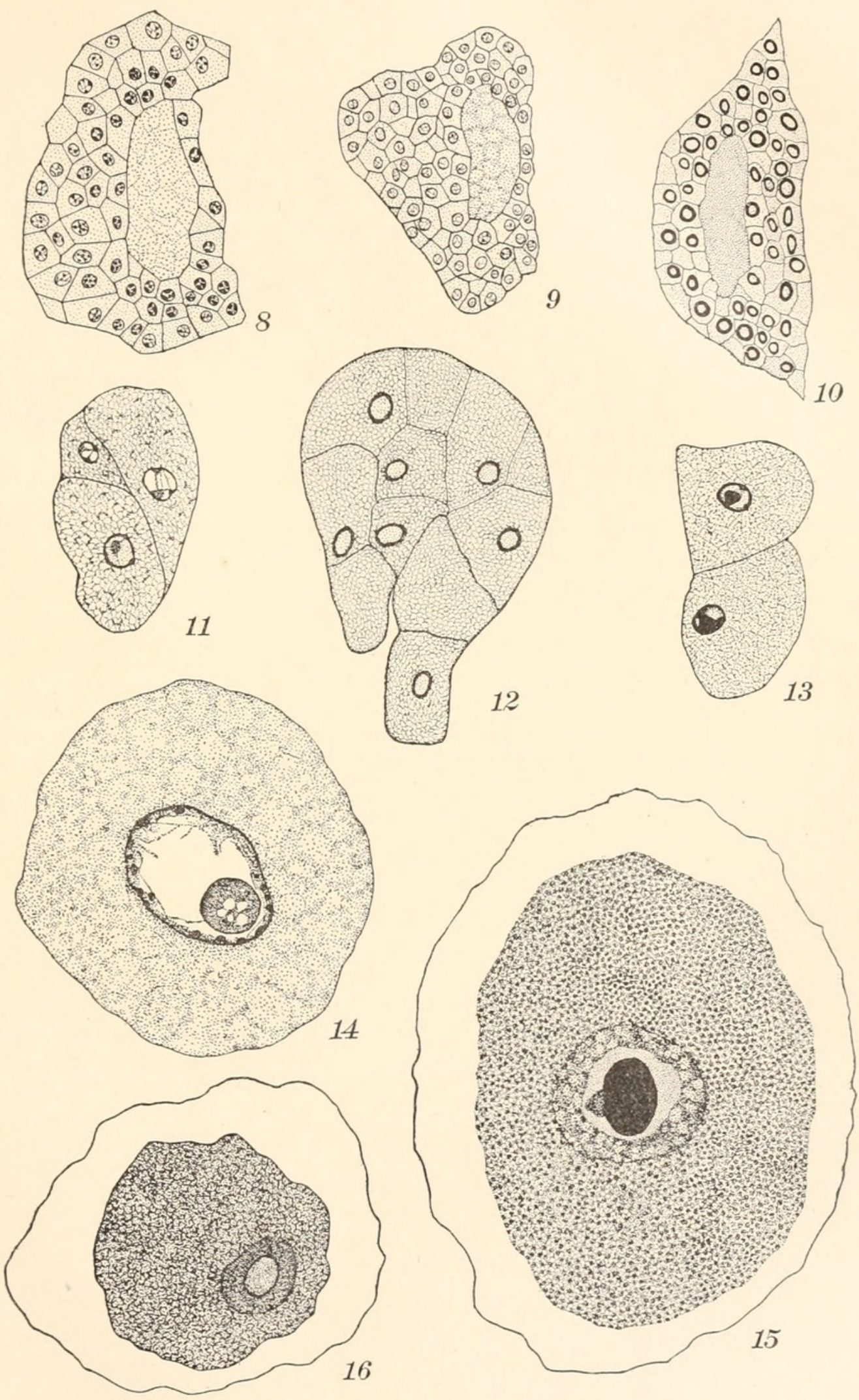

LOUIS M. HICKERNELL. 



\title{
REGULATION IN VORTICELLA.
}

\author{
E. M. RUNYAN AND H. B. TORREY.
}

(From the Department of Biology, Reed College, Portland, Oregon.)

It is a fact well known to students of regeneration that one part of an organism may exert a measurable influence over the growth and development of another. This has been demonstrated for many of the Metazoa under varying forms. The removal of the head of a planarian liberates, as it were, the postjacent tissue, out of which a new head is fashioned. Among macruran crustaceans, the loss of the larger chela of an asymmetrical pair has been shown many times to be succeeded by an accelerated growth of the smaller chela and a subsequent retardation in the regeneration of the lost chela so that, in the presence of the small chela grown large, it remains the smaller of the two. Finally-not to multiply instances needlessly - when a short length of the column, with hydranth, is cut away from the hydroid Corymorpha, no development beyond closure of the wound occurs proximally until the hydranth is removed from the distal end. In this respect, the behavior of Corymorpha may be contrasted with the behavior of the planarian, since in the latter the presence of the original head on the anterior piece does not inhibit the development of a tail posteriorly. The hydranth in Corymorpha appears somehow to inhibit, in short pieces, even the development normally to be expected at the aboral end.

Among the Protozoa, instances of this last sort seem so generally to have escaped record, that we have thought it desirable to describe a similar domination in Vorticella sp. of one part over another.

When Vorticella divides, the fission plane passes approximately through the center of the organism from oral disk to a point immediately to one side of the contractile stalk. Of the zoöids thus formed, one remains attached to the original stalk, while the other swims away by means of cilia which, during the 
last phases of the process of fission, have appeared in a circlet near the aboral pole (Fig. I). ${ }^{1}$

Why do such cilia not appear on the stalked zoöid?

It may be noticed in the last stages of fission that the zoöid destined to become free retains its connection by a slender protoplasmic strand with the body of the stalked zoöid, not directly with the stalk itself. This fact suggests what has proven to be the correct view, namely, that cilia which would normally develop on every individual are able to show themselves only when sufficiently isolated physiologically from the stalk. Such isolation exists when the connection between the separating zoöids is reduced to a narrow strand.

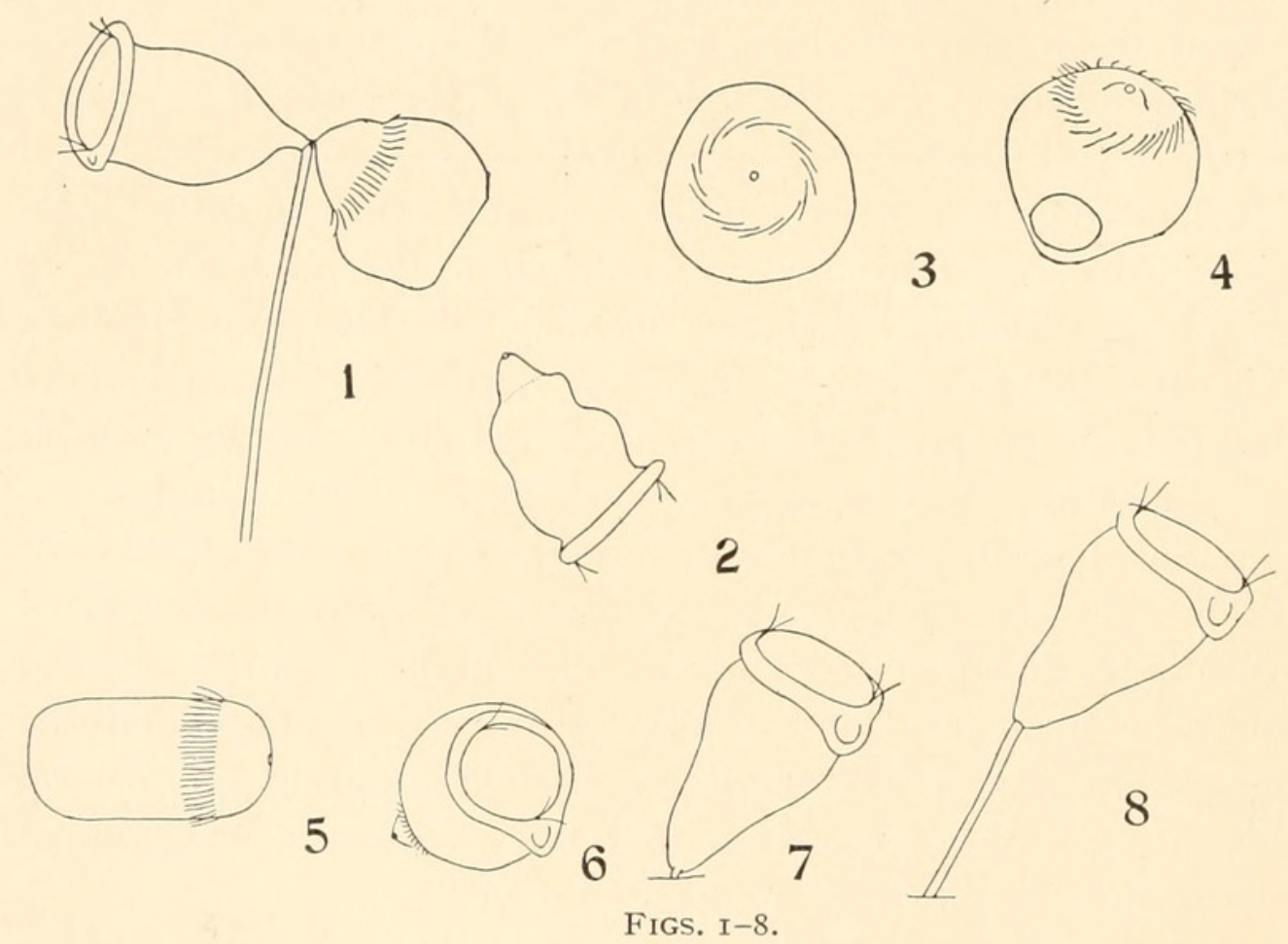

This view was reinforced by the familiar fact that, upon becoming attached to the substrate, the free zoöid gradually loses its cilia as its stalk develops. In the normal life history, then, aboral cilia develop in isolation from the stalk and disappear with the development of the stalk.

The test was applied by cutting a stalked zoöid quite away from the stalk. This was accomplished under a binocular, by

${ }_{1}$ The figures have not been drawn with a camera. Their scale varies somewhat. 
means of a sharp dissecting needle. A typical case is shown in Figs. 2-8. Soon after the cutting, the zoöid (Fig. 2) settled down on its oral surface. In an hour, cilia began to push out in a circlet near the aboral pole. They elongated rapidly, and began to beat around the oral-aboral axis (Fig. 3). The oral disk turned in upon itself in the manner characteristic of the normally free zoöid (Fig. 4). One hundred and five minutes after the operation, the zoöid swam away (Fig. 5), indistinguishable in every respect from the normally free form. After five minutes of active locomotion, it came to rest on its aboral end, became attached, and unfolded its oral disk (Fig. 6). At once the stalk began to grow and the aboral cilia to disappear. In ten minutes no aboral cilia were to be seen (Fig. 7). Two hours and a half later, the organism appeared as in Fig. 8.

The development of the stalk appears to be dependent on contact at the aboral end; while the development of aboral cilia is conditioned by physiological isolation from the stalk whether achieved experimentally or by a narrowing of protoplasmic connection in the ordinary course of fission. 



anal.

ang.3/ $1915^{5}$

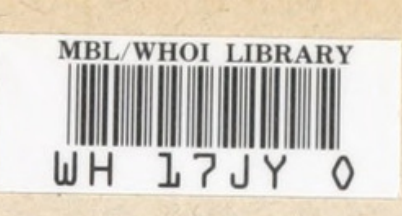

$504 c$ 


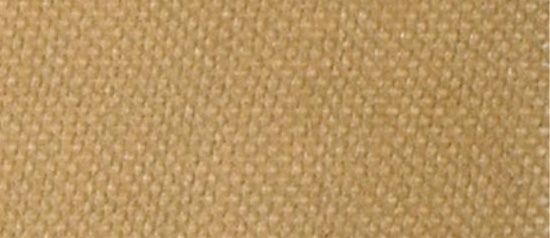

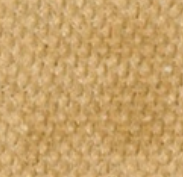
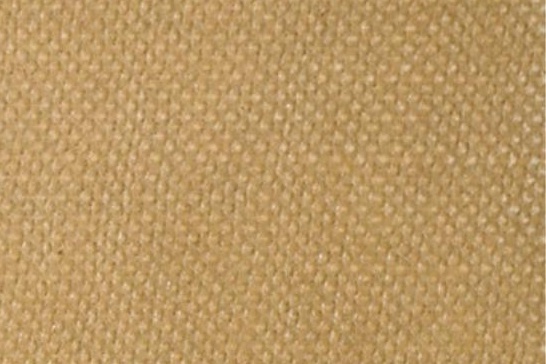

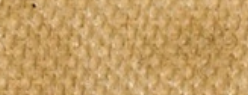

Whos

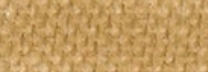

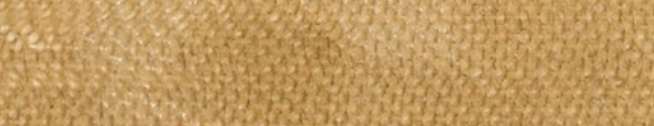
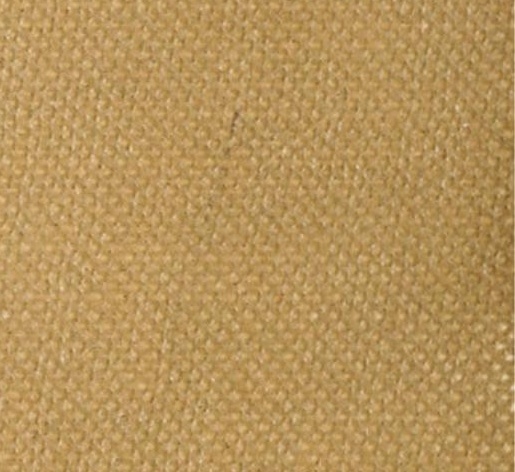


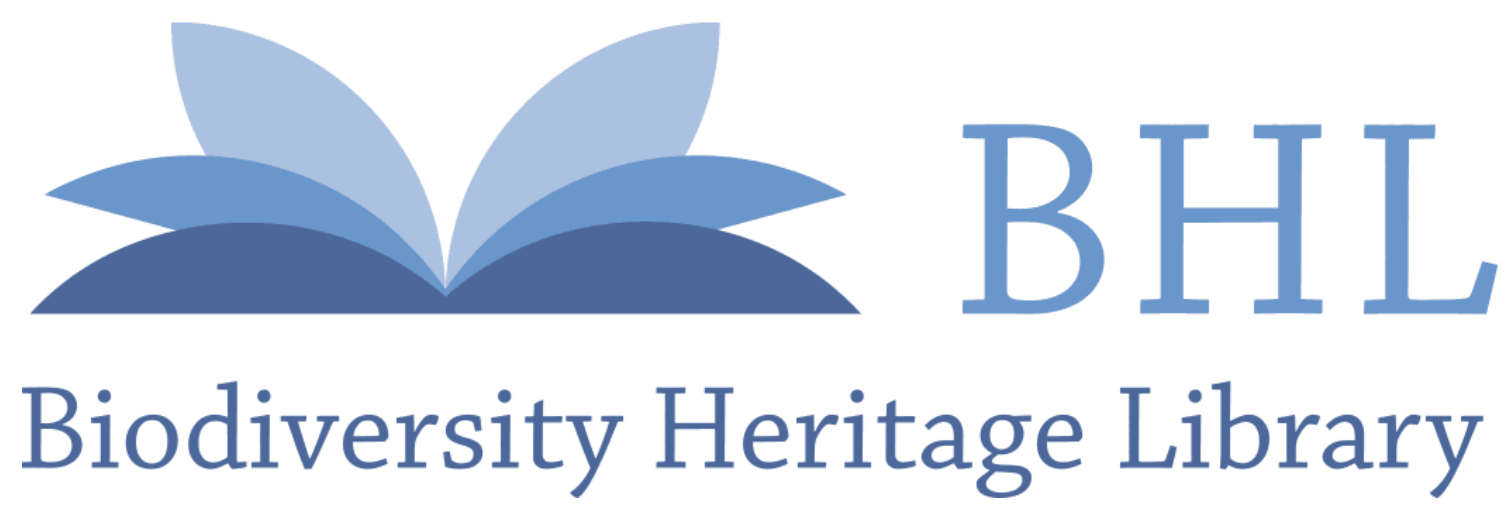

Kingery, H M. 1914. "SO-CALLED PARTHENOGENESIS IN THE WHITE MOUSE." The Biological bulletin 27, 240-258. https://doi.org/10.2307/1536184.

View This Item Online: https://www.biodiversitylibrary.org/item/15881

DOI: https://doi.org/10.2307/1536184

Permalink: https://www.biodiversitylibrary.org/partpdf/26155

\section{Holding Institution}

MBLWHOI Library

Sponsored by

MBLWHOI Library

\section{Copyright \& Reuse}

Copyright Status: NOT_IN_COPYRIGHT

This document was created from content at the Biodiversity Heritage Library, the world's largest open access digital library for biodiversity literature and archives. Visit BHL at https://www.biodiversitylibrary.org. 